\title{
Factors Affecting Water Quality in Domestic Wells in the Upper Floridan Aquifer, Southeastern United States, 1998-2005
}

By Marian P. Berndt and Christy A. Crandall

National Water-Quality Assessment Program

Scientific Investigations Report 2009-5147 


\title{
U.S. Department of the Interior \\ KEN SALAZAR, Secretary
}

\author{
U.S. Geological Survey \\ Suzette M. Kimball, Acting Director
}

U.S. Geological Survey, Reston, Virginia: 2009

For more information on the USGS - the Federal source for science about the Earth, its natural and living resources, natural hazards, and the environment, visit http://www.usgs.gov or call 1-888-ASK-USGS

For an overview of USGS information products, including maps, imagery, and publications, visit http://www.usgs.gov/pubprod

To order this and other USGS information products, visit http://store.usgs.gov

Any use of trade, product, or firm names is for descriptive purposes only and does not imply endorsement by the U.S. Government.

Although this report is in the public domain, permission must be secured from the individual copyright owners to reproduce any copyrighted materials contained within this report.

Suggested citation:

Berndt, M.P., and Crandall, C.A., 2009, Factors Affecting Water Quality in Domestic Wells in the Upper Floridan Aquifer, Southeastern United States, 1998-2005: U.S. Geological Survey Scientific Investigations Report 2009-5147, $39 \mathrm{p}$.

ISBN 0-607-97815-5 


\section{Foreword}

The U.S. Geological Survey (USGS) is committed to providing the Nation with reliable scientific information that helps to enhance and protect the overall quality of life and that facilitates effective management of water, biological, energy, and mineral resources (http://www.usgs.gov/). Information on the Nation's water resources is critical to ensuring long-term availability of water that is safe for drinking and recreation and is suitable for industry, irrigation, and fish and wildlife. Population growth and increasing demands for water make the availability of that water, measured in terms of quantity and quality, even more essential to the long-term sustainability of our communities and ecosystems.

The USGS implemented the National Water-Quality Assessment (NAWOA) Program in 1991 to support national, regional, State, and local information needs and decisions related to water-quality management and policy (http://water.usgs.gov/nawqa). The NAWQA Program is designed to answer: What is the quality of our Nation's streams and groundwater? How are conditions changing over time? How do natural features and human activities affect the quality of streams and groundwater, and where are those effects most pronounced? By combining information on water chemistry, physical characteristics, stream habitat, and aquatic life, the NAWQA Program aims to provide science-based insights for current and emerging water issues and priorities. From 1991 to 2001, the NAWOA Program completed interdisciplinary assessments and established a baseline understanding of water-quality conditions in 51 of the Nation's river basins and aquifers, referred to as Study Units (http:// water.usgs.gov/nawqa/studyu.htm/.

In the second decade of the Program (2001-2012), a major focus is on regional assessments of water-quality conditions and trends. These regional assessments are based on major river basins and principal aquifers, which encompass larger regions of the country than the Study Units. Regional assessments extend the findings in the Study Units by filling critical gaps in characterizing the quality of surface water and groundwater, and by determining water-quality status and trends at sites that have been consistently monitored for more than a decade. In addition, the regional assessments continue to build an understanding of how natural features and human activities affect water quality. Many of the regional assessments employ modeling and other scientific tools, developed on the basis of data collected at individual sites, to help extend knowledge of water quality to unmonitored, yet comparable areas within the regions. The models thereby enhance the value of our existing data and our understanding of the hydrologic system. In addition, the models are useful in evaluating various resource-management scenarios and in predicting how our actions, such as reducing or managing nonpoint and point sources of contamination, land conversion, and altering flow and (or) pumping regimes, are likely to affect water conditions within a region.

Other activities planned during the second decade include continuing national syntheses of information on pesticides, volatile organic compounds (VOCs), nutrients, trace elements, and aquatic ecology; and continuing national topical studies on the fate of agricultural chemicals, effects of urbanization on stream ecosystems, bioaccumulation of mercury in stream ecosystems, effects of nutrient enrichment on stream ecosystems, and transport of contaminants to public-supply wells.

The USGS aims to disseminate credible, timely, and relevant science information to address practical and effective water-resource management and strategies that protect and restore water quality. We hope this NAWOA publication will provide you with insights and information to meet your needs, and will foster increased citizen awareness and involvement in the protection and restoration of our Nation's waters.

The USGS recognizes that a national assessment by a single program cannot address all water-resource issues of interest. External coordination at all levels is critical for cost-effective management, regulation, and conservation of our Nation's water resources. The NAWQA Program, therefore, depends on advice and information from other agencies-Federal, State, regional, interstate, Tribal, and local—as well as nongovernmental organizations, industry, academia, and other stakeholder groups. Your assistance and suggestions are greatly appreciated. 


\section{Contents}

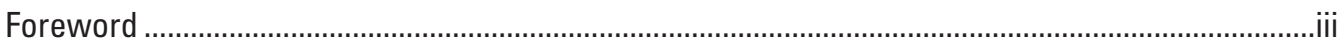

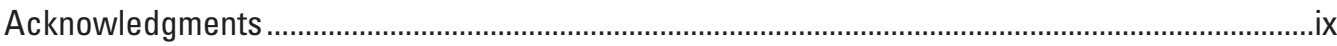

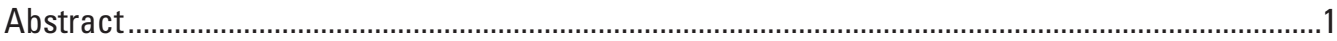

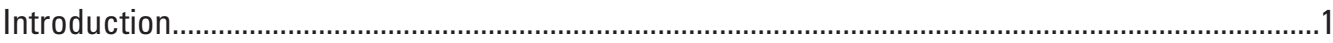

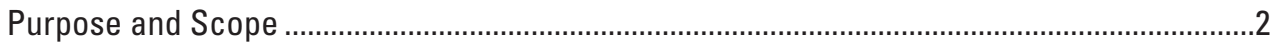

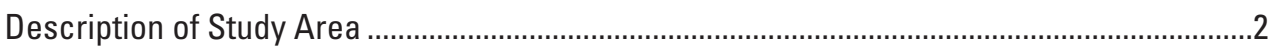

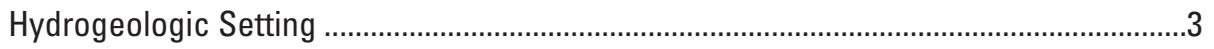

Land Use, Population, and Water Use .......................................................................

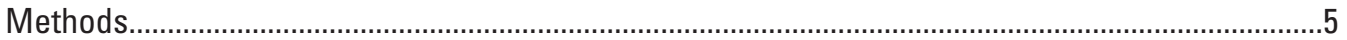

Sample Collection and Processing .........................................................................................

Quality Assurance and Quality Control ......................................................................................5

Water-Quality Benchmarks for Human Health ..........................................................................6

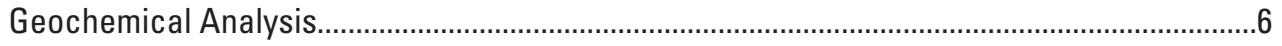

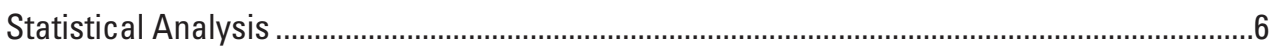

Compilation of Ancillary Data ...............................................................................................

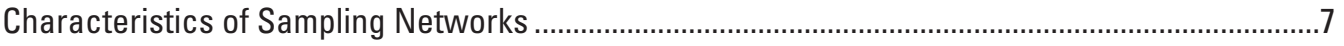

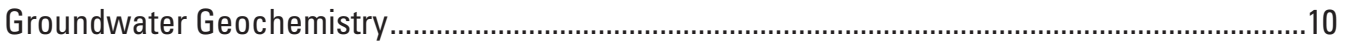

Dissolved Solids, Dissolved Oxygen, Major lons, and pH....................................................10

Mineral Saturation Indices ................................................................................................ 16

Trace Elements and Radon.............................................................................................. 18

Occurrence and Distribution of Selected Contaminants ..............................................................20

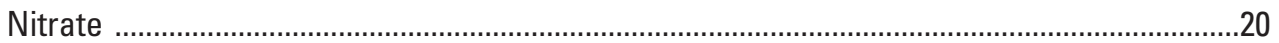

Occurrence and Distribution of Nitrate .........................................................................20

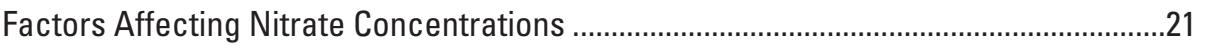

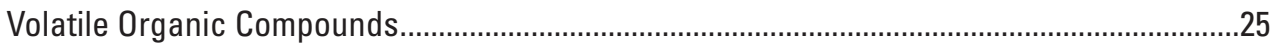

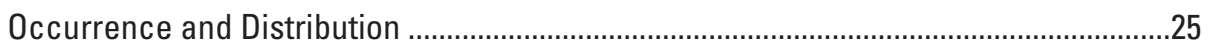

Comparison to Water-Quality Benchmarks for Human Health ..........................................26

Factors Affecting Volatile Organic Compound Detections .................................................28

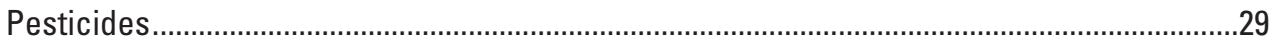

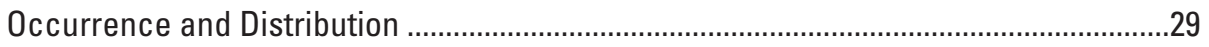

Comparison to Water-Quality Benchmarks for Human Health ..........................................30

Factors Affecting Pesticide Detections .............................................................................30

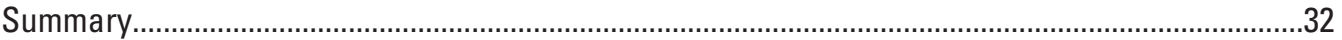

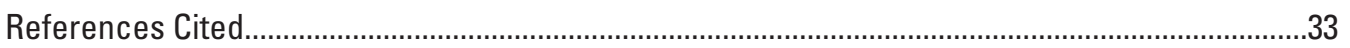

Appendix 1. Volatile organic compounds analyzed in water samples..............................................37

Appendix 2. Pesticides analyzed in water samples. ...................................................................38

\section{Figures}

1. Map showing extent of the Floridan aquifer system in the southeastern United States

2. Map showing unconfined, semiconfined, and confined areas of the Upper Floridan aquifer and locations of domestic wells sampled 
3. Cross sections showing the general hydrogeology in the unconfined, semiconfined, and confined areas of the Upper Floridan aquifer

4-5. Maps showing-

4. Generalized land use and land cover overlying the Floridan aquifer system, 1992-98.

5. Population by county in areas overlying the Floridan aquifer system, 2000...............4

6. Water withdrawals by county from the Floridan aquifer system, $2000 \ldots \ldots \ldots \ldots \ldots \ldots \ldots . . . .5$

7. Boxplot showing distribution of depths of domestic wells by sampling network..............8

8. Map showing spatial distribution of dissolved-solids concentration in domestic wells in the Upper Floridan aquifer.

9. Piper diagram showing major-ion composition of water in domestic wells in the Upper Floridan aquifer

10. Map showing spatial distribution of major-ion water types from domestic wells in the Upper Floridan aquifer

11. Graphs showing molar concentrations of calcium plus magnesium compared to bicarbonate in domestic wells in the Upper Floridan aquifer for unconfined areas, semiconfined areas, and confined areas; and molar concentration of bicarbonate to sodium in semiconfined areas in South Carolina

12. Boxplots showing distribution of calcite saturation index values, dolomite saturation index values, and calcium to magnesium molar ratios by sampling network

13. Map showing spatial distribution of calcium to magnesium molar ratios in domestic wells in the Upper Floridan aquifer

14. Map showing spatial distribution of radon concentrations in domestic wells in the Upper Floridan aquifer

15. Map showing spatial distribution of nitrate concentration in domestic wells in the Upper Floridan aquifer

16. Graph showing percentage of nitrate concentrations at selected concentration levels in the entire data set and by sampling network

17. Boxplots showing concentrations of nitrate and dissolved oxygen concentrations in domestic wells in the Upper Floridan aquifer by confinement category

18. Boxplots showing distribution by sampling network of nitrate, dissolved oxygen, and dissolved organic carbon concentrations; and estimated nitrogen contributions in the 500-m-radius area surrounding each well from fertilizer, animal manure, and septic tanks.

19-27. Graphs showing-

19. Detection frequencies for samples with one to five volatile organic compound detections per sample

20. Detection frequencies for samples with volatile organic compound detections in each sampling network

21. Detection frequencies for volatile organic compounds detected in more than 3 percent of samples

22. Concentrations and benchmark quotient values for volatile organic compounds and pesticides detected in 3 percent or more of samples.

23. Detection frequencies for chloroform, carbon disulfide, and 1,2-dichloropropane

by confinement category and land-use category

24. Detection frequencies for samples with one to five pesticide detections per sample

25. Detection frequencies for samples with pesticide detections in each sampling network. 
26. Detection frequencies for pesticides detected in 1 percent or more of samples.

27. Detection frequencies for atrazine, deethylatrazine, metolachlor, and alachlor by confinement category and land-use category

\section{Tables}

1. Classification strategy for the dominant land use in the 500-meter radius area surrounding each domestic well site in the Upper Floridan aquifer.

2. Description of sampling networks of domestic wells in the Upper Floridan aquifer ........8

3. Median values for land use, nitrogen sources, population density, and soil properties in the areas surrounding domestic wells for all data, the three confinement categories, and the five sampling networks.

4. Summary statistics of well depth, temperature, $\mathrm{pH}$, major ions, and selected chemical constituents in domestic wells in the Upper Floridan aquifer

5. Summary statistics by sampling network of well depth, temperature, $\mathrm{pH}$, major ions, and selected chemical constituents in domestic wells in the Upper Floridan aquifer

6. Comparison of $\mathrm{pH}$ and concentrations of major ions in domestic wells in the Upper Floridan aquifer to human-health benchmarks and non-health guidelines for drinking water

7. Descriptive statistics of concentrations of trace elements in domestic wells in the Upper Floridan aquifer

8. Comparison of concentrations of trace elements in domestic wells in the Upper Floridan aquifer to human-health benchmarks and non-health guidelines for drinking water

9. Median nitrate concentrations in domestic wells in the Upper Floridan aquifer and results of the Peto-Prentice test to determine differences in concentration among the three confinement categories

10. Results of the Peto-Prentice test to determine differences in nitrate concentration in domestic wells in the Upper Floridan aquifer between individual confinement categories using pairwise comparisons.

11. Median nitrate concentration in domestic wells in the Upper Floridan aquifer and results of the Peto-Prentice test to determine differences in concentration among the five sampling networks.

12. Results of the Peto-Prentice test to determine differences in nitrate concentration in domestic wells in the Upper Floridan aquifer between individual sampling networks using pairwise comparisons

13. Results of correlation tests between nitrate concentration and selected explanatory variables using Kendall's tau for censored data

14. Results of the Wilcoxon rank-sum test comparing median values for selected chemical and anthropogenic factors between samples with chloroform detections and samples without chloroform detections

15. Results of the Wilcoxon rank-sum test comparing median values for selected chemical and anthropogenic factors between samples with carbon disulfide detections and samples without carbon disulfide detections

16. Results of the Wilcoxon rank-sum test comparing median values for selected chemical and anthropogenic factors between samples with atrazine detections and samples without atrazine detections. 


\section{Conversion Factors and Abbreviations}

\begin{tabular}{lcl}
\hline \multicolumn{1}{c}{ Multiply } & By & To obtain \\
\hline & Length & \\
meter $(\mathrm{m})$ & 3.281 & foot $(\mathrm{ft})$ \\
kilometer $(\mathrm{km})$ & 0.6214 & mile $(\mathrm{mi})$ \\
meter $(\mathrm{m})$ & 1.094 & yard $(\mathrm{yd})$ \\
\hline & Area & \\
\hline square kilometer $\left(\mathrm{km}^{2}\right)$ & 0.3861 & square mile $\left(\mathrm{mi}^{2}\right)$ \\
\hline & Mass & \\
\hline gram $(\mathrm{g})$ & 0.03527 & ounce, avoirdupois $(\mathrm{oz})$ \\
kilogram $(\mathrm{kg})$ & 2.205 & pound avoirdupois $(\mathrm{lb})$ \\
\hline & Flow rate & \\
\hline cubic meter per second $\left(\mathrm{m}^{3} / \mathrm{s}\right)$ & 35.31 & cubic foot per second $(\mathrm{ft} / \mathrm{s})$ \\
cubic meter per day $\left(\mathrm{m}^{3} / \mathrm{d}\right)$ & 0.000264 & million gallons $\mathrm{per}$ day $(\mathrm{gal} / \mathrm{d})$ \\
\hline & Radioactivity & \\
\hline picocurie per liter $(\mathrm{pCi} / \mathrm{L})$ & 0.037 & becquerel per liter $(\mathrm{Bq} / \mathrm{L})$ \\
\hline
\end{tabular}

Temperature in degrees Celsius $\left({ }^{\circ} \mathrm{C}\right)$ may be converted to degrees Fahrenheit $\left({ }^{\circ} \mathrm{F}\right)$ as follows:

${ }^{\circ} \mathrm{F}=\left(1.8 \mathrm{x}^{\circ} \mathrm{C}\right)+32$

Specific conductance is given in microsiemens per centimeter at 25 degrees Celsius $(\mu \mathrm{S} / \mathrm{cm}$ at $\left.25^{\circ} \mathrm{C}\right)$.

Concentrations of chemical constituents in water are given either in milligrams per liter (mg/L) or micrograms per liter $(\mu \mathrm{g} / \mathrm{L})$.

Concentrations of radioisotopes in water are given in picocuries per liter ( $\mathrm{pCi} / \mathrm{L})$.

\section{Acronyms and Additional Abbreviations}

CFC-12

HBSL

$\mathrm{kg} / \mathrm{lb}$

$\mathrm{kg} / \mathrm{yr}$

$\mathrm{lb} / \mathrm{yr}$

lb/yr-person

$\mathrm{MCL}$

$\mathrm{mg} / \mathrm{L}$

NLCD

NAWOA

people $/ \mathrm{km}^{2}$

PCE

SI

SMCL

STATSGO

USEPA

USGS

VOC
Dichlorodifluoromethane

Health-Based Screening Levels

conversion of kilograms to pounds

kilogram per year

pound per year

pound per year per person

Maximum Contaminant Levels

milligram per liter

National Land Cover Data

National Water-Quality Assessment Program

People per square kilometer

Tetrachloroethene

Saturation Index

Secondary Maximum Contaminant Level

State Soil Geographic Data Base

U.S. Environmental Protection Agency

U.S. Geological Survey

Volatile Organic Compounds 


\section{Acknowledgments}

Appreciation is extended to all the homeowners in Florida, Georgia, South Carolina, and Alabama who allowed the USGS to sample their domestic wells.

Gratitude is expressed to the many USGS field personnel in Florida, Georgia, and South Carolina who collected the samples. Thanks also to Terri L. Arnold, USGS Illinois Water Science Center, for providing the land-use data and map for the Floridan aquifer system.

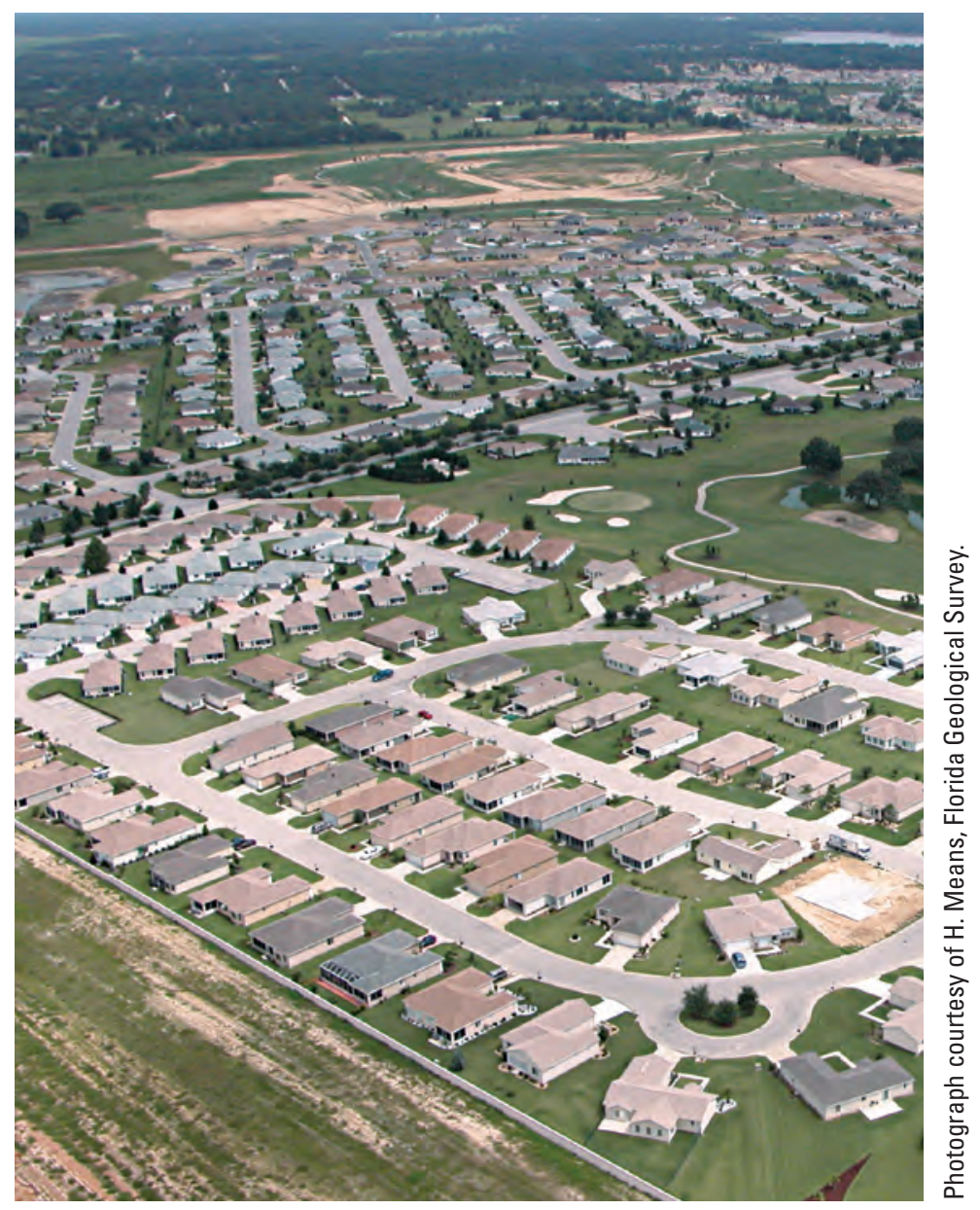





\title{
Factors Affecting Water Quality in Domestic Wells in the Upper Floridan Aquifer, Southeastern United States, 1998-2005
}

\author{
By Marian P. Berndt and Christy A. Crandall
}

\section{Abstract}

The Floridan aquifer system is a highly productive carbonate aquifer that provides drinking water to about 10 million people in Florida, Georgia, and South Carolina. Approximately 1.6 million people rely on domestic wells (privately owned household wells) for drinking water. Withdrawals of water from the Floridan aquifer system have increased by more than 500 percent from 630 million gallons per day ( 2.38 cubic meters per day) in 1950 to 4,020 million gallons per day ( 15.2 cubic meters per day) in 2000, largely due to increases in population, tourism, and agriculture production.

Water samples were collected from 148 domestic wells in the Upper Floridan aquifer in Florida, Georgia, South Carolina, and Alabama during 1998-2005 as part of the U.S. Geological Survey (USGS) National Water-Quality

Assessment Program. The wells were located in different hydrogeologic settings based on confinement of the Upper Floridan aquifer. Five networks of wells were sampled consisting of 28 to 30 wells each - two networks were in unconfined areas, two networks were in semiconfined areas, and one network was in the confined area. Physical properties and concentrations of major ions, trace elements, nutrients, radon, and organic compounds (volatile organic compounds and pesticides) were measured in water samples. Concentrations were compared to water-quality benchmarks for human health, either U.S. Environmental Protection Agency (USEPA) Maximum Contaminant Levels (MCLs) for public water supplies or USGS Health-Based Screening Levels (HBSLs). The MCL for fluoride of 4 milligrams per liter $(\mathrm{mg} / \mathrm{L})$ was exceeded for two samples (about 1 percent of samples). A proposed MCL for radon of 300 picocuries per liter was exceeded in about 40 percent of samples.

Nitrate concentrations in the Upper Floridan aquifer ranged from less than the laboratory reporting level of 0.06 to $8 \mathrm{mg} / \mathrm{L}$, with a median nitrate concentration less than
$0.06 \mathrm{mg} / \mathrm{L}$ (as nitrogen). Nitrate concentrations did not exceed the MCL of $10 \mathrm{mg} / \mathrm{L}$. Statistical comparisons indicated that median nitrate concentrations were significantly different by degree of confinement where the highest median nitrate concentration was $1.46 \mathrm{mg} / \mathrm{L}$ for 58 samples from unconfined areas, and by network, where the highest median nitrate concentration was $2.43 \mathrm{mg} / \mathrm{L}$ in 28 samples from unconfined areas in southwestern Georgia. Nitrate concentrations in unconfined areas were positively correlated to: (1) the percentage of agricultural land use around the well, (2) the amount of nitrogen fertilizer applied, and (3) the dissolved oxygen concentrations in groundwater.

Volatile organic compounds (VOCs) were detected in about 63 percent of all samples. Chloroform, carbon disulfide, and 1,2-dichloropropane were the most frequently detected VOCs. Chloroform, a byproduct of water chlorination, was most frequently detected in unconfined urban areas. Carbon disulfide, a solvent, was most frequently detected in confined areas in southeastern Georgia. Pesticides were detected in about 21 percent of all samples, but were detected in about 69 percent of the 28 samples from unconfined areas in southwestern Georgia. The herbicides atrazine, deethylatrazine, and metolachlor were the most frequently detected pesticides.

\section{Introduction}

The Floridan aquifer system is the primary source of drinking water for nearly 10 million people in the southeastern United States. Of the 10 million people, an estimated 8.2 million people obtained drinking water from publicwater supplies in 2000, and an estimated 1.6 million obtained drinking water from domestic wells (privately owned wells primarily used for household drinking water) in 2000 (Marella and Berndt, 2005). This aquifer system also supports agriculture, industry and tourism. 
The Floridan aquifer system consists of up to 1,000 meters $(\mathrm{m})$ of carbonate rock (limestone and dolomite) (Miller, 1990). The porous nature of the limestone and its proximity to the surface in some areas results in a groundwater resource that is particularly vulnerable to contamination from various land-use activities. This vulnerability, in some areas, is due in part to the presence of numerous karst features, such as sinkholes, which facilitate the movement of water from surface features and overlying hydrogeologic units to the uppermost unit of this aquifer system, the Upper Floridan aquifer.

The Floridan aquifer system is one of the principal aquifers in the United States studied as part of the National Water-Quality Assessment (NAWQA) Program of the U.S. Geological Survey (USGS) (Lapham and others, 2005) to increase the understanding of how natural features and human activities affect groundwater quality. Because of the large number of people relying on the Upper Floridan aquifer for water supply from domestic wells and the relative vulnerability of this aquifer to contamination, an assessment of the relation between geochemical, hydrogeologic and anthropogenic (land use and population density) factors can help water-resource managers assess the vulnerability of this important drinking-water source to contamination.

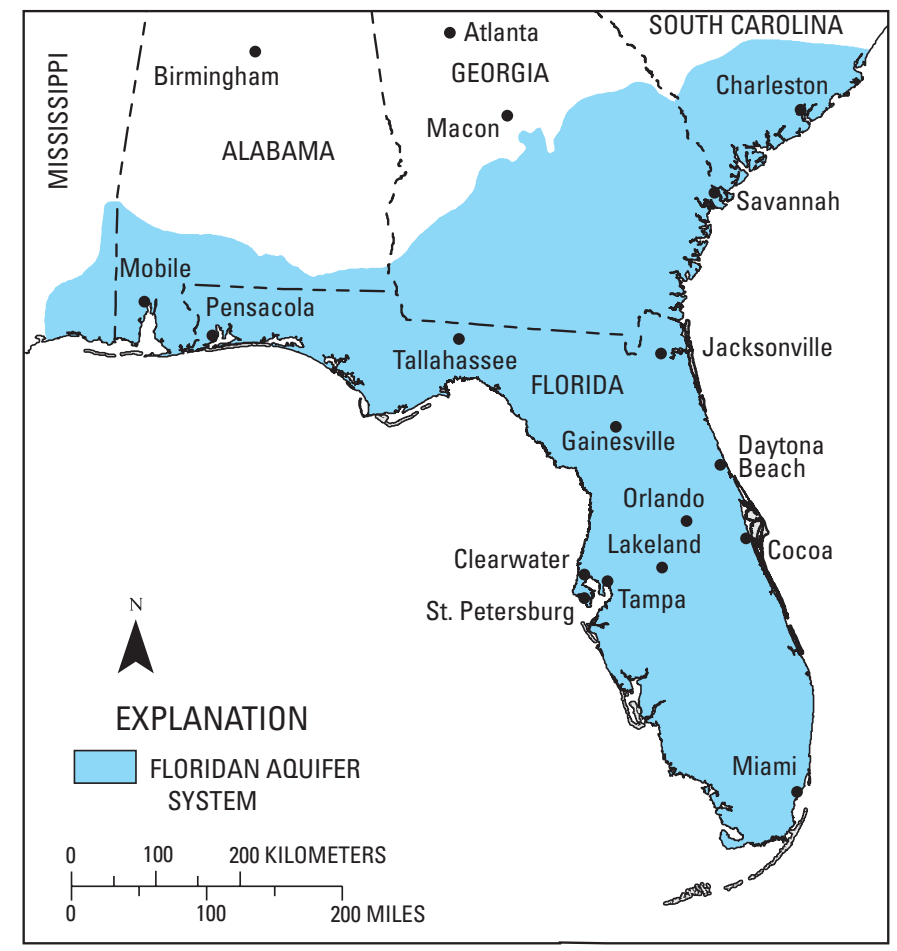

Figure 1. Extent of the Floridan aquifer system in the southeastern United States.

\section{Purpose and Scope}

This report describes the factors affecting water quality in domestic wells in the Upper Floridan aquifer of the Floridan aquifer system in the southeastern United States. Water samples were collected from 148 domestic wells in Florida, Georgia, South Carolina, and Alabama during 19982005 as part of the NAWQA Program's assessment of groundwater quality in principal aquifers. The five networks of 28 to 30 wells each were sampled in areas classified on the basis of the confinement conditions of the Upper Floridan aquifertwo networks were in unconfined areas of southwestern Georgia and northern Florida, two networks were in semiconfined areas of northern Florida and southern South Carolina, and one network was in confined areas in southeastern Georgia. The network in the unconfined area in southwestern Georgia includes 2 wells in Alabama and 3 wells in Florida; the network in the semiconfined area in northern Florida includes 2 wells in Georgia; and the network in the confined area in southeastern Georgia includes 4 wells in Florida.

Samples from the domestic wells were analyzed for physical properties and concentrations of major ions, trace elements, nutrients, radon, volatile organic compounds (VOCs) and pesticides.

The quality of groundwater is described for the entire data set and for each sampling network. The geochemical and anthropogenic factors affecting the occurrence and distribution of contaminants were determined by comparing concentrations for nitrate and detection frequencies for pesticides and VOCs in the sampling networks, confinement categories, and major land-use categories. The land-use categories were based on the predominant land use in the area surrounding each well, which were derived from national-scale data sets for land use.

For this assessment, measured concentrations were compared to water-quality benchmarks for human health, U.S. Environmental Protection Agency Maximum Contaminant Levels (MCLs) and USGS Health-Based Screening Levels (HBSLs), to describe the potential importance of water-quality results for human health. Measured concentrations were also compared to secondary maximum contaminant levels (SMCLs), which are non-enforceable guidelines (established for non-health issues such as taste, color, odor, or corrosion), to describe the suitability of the water for household supply.

\section{Description of Study Area}

The Floridan aquifer system underlies an area encompassing about 260,000 $\mathrm{km}^{2}$ in southern Alabama, southern Georgia, southeastern Mississippi, southern South Carolina, and all of Florida (fig. 1). The study area for this report covers approximately 60 percent of the areal extent of the Floridan aquifer system and includes most of the areas where this aquifer system is a primary source of drinking water. 


\section{Hydrogeologic Setting}

The Floridan aquifer system is composed of a thick sequence of highly permeable and hydraulically connected carbonate rocks (principally limestone and dolomite) that generally range in age from late Paleocene to early Miocene. The rocks vary in thickness from a thin edge where they crop out at land surface to more than $1,000 \mathrm{~m}$ thick where the aquifer system is deeply buried in southern Florida (Miller, 1990). In most places, the Floridan aquifer system can be divided into three units: (1) the Upper Floridan aquifer, (2) the middle confining unit, and (3) the Lower Floridan aquifer. The middle confining unit restricts the movement of groundwater between the Upper and Lower Floridan aquifers. Both the Upper and Lower Floridan aquifers are defined on the basis of permeability, and their boundaries locally do not coincide with those for either formation boundaries or time-stratigraphic units (Miller, 1986). In places where no middle confining unit exists, the aquifer system is highly permeable throughout its vertical extent and is known as the Upper Floridan aquifer (Miller, 1986). The Upper Floridan aquifer is the primary source of drinking water.

A sequence of sand, clay, marl, limestone, and dolomite of low permeability overlies much of the Upper Floridan aquifer and forms a confining unit, which ranges in thickness from a few meters in parts of southwestern Georgia and westcentral and north-central Florida to more than $100 \mathrm{~m}$ in southeastern Georgia, northeastern Florida, southeastern Florida,

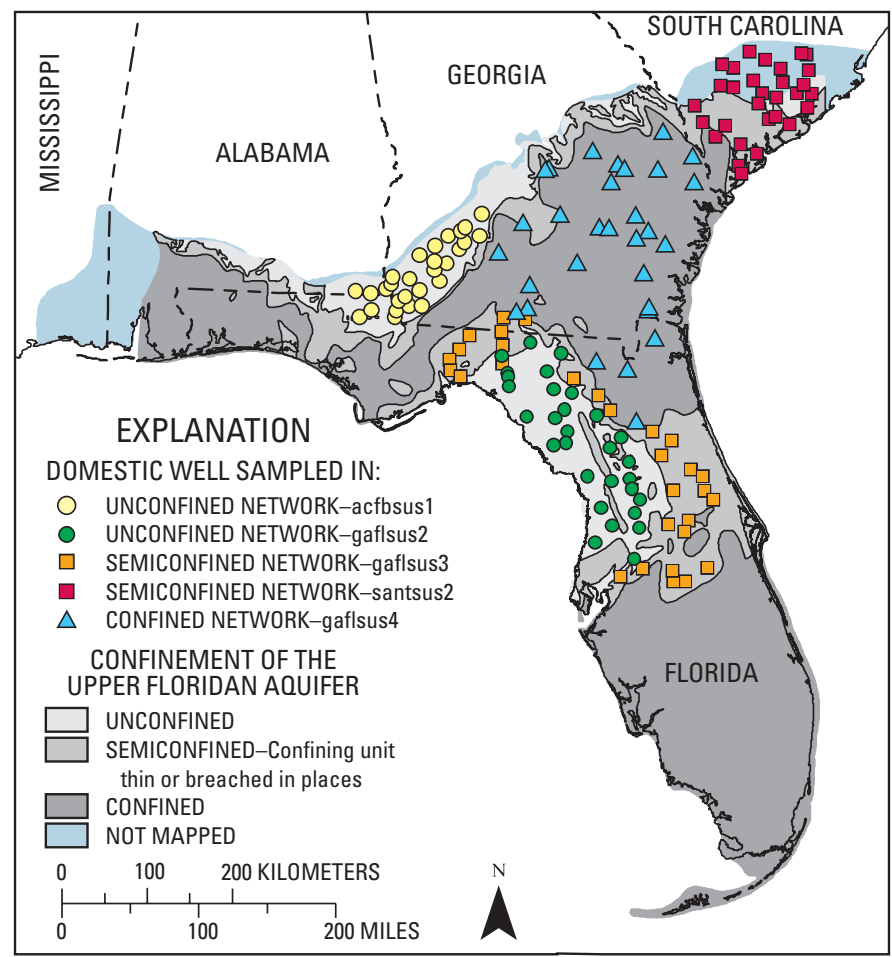

Figure 2. Unconfined, semiconfined, and confined areas of the Upper Floridan aquifer and locations of domestic wells sampled. (Confinement map modified from Miller, 1986.) and the western part of the panhandle of Florida. The lithology, thickness, and integrity of these low-permeability units have a controlling effect on the development of permeability and local groundwater flow (Bush and Johnston, 1988). The sand layers are generally referred to as the surficial aquifer system, whereas the clay and limestone components comprise the intermediate aquifer system or the intermediate confining unit. Both the surficial and intermediate aquifer systems act as confining units to the Upper Floridan aquifer. The unconfined areas of the Upper Floridan aquifer are located in the western parts of north-central Florida and in southwestern Georgia (fig. 2). Three confinement categories were defined by Miller (1986): (1) unconfined (confining units are absent),

(2) semiconfined (confining unit less than $30 \mathrm{~m}$ thick or breached), and confined (confining unit more than $30 \mathrm{~m}$ thick) (fig. 2). Generalized hydrogeologic sections of the unconfined, semiconfined, and confined areas of the Upper Floridan aquifer are shown in figure 3 . The carbonate rocks of the Upper Floridan aquifer are readily dissolved in unconfined areas (Miller, 1990). In these areas, dissolution of limestone is greatest because water is able to enter and move through the aquifer quickly. Water also discharges to surface water quickly through numerous springs.
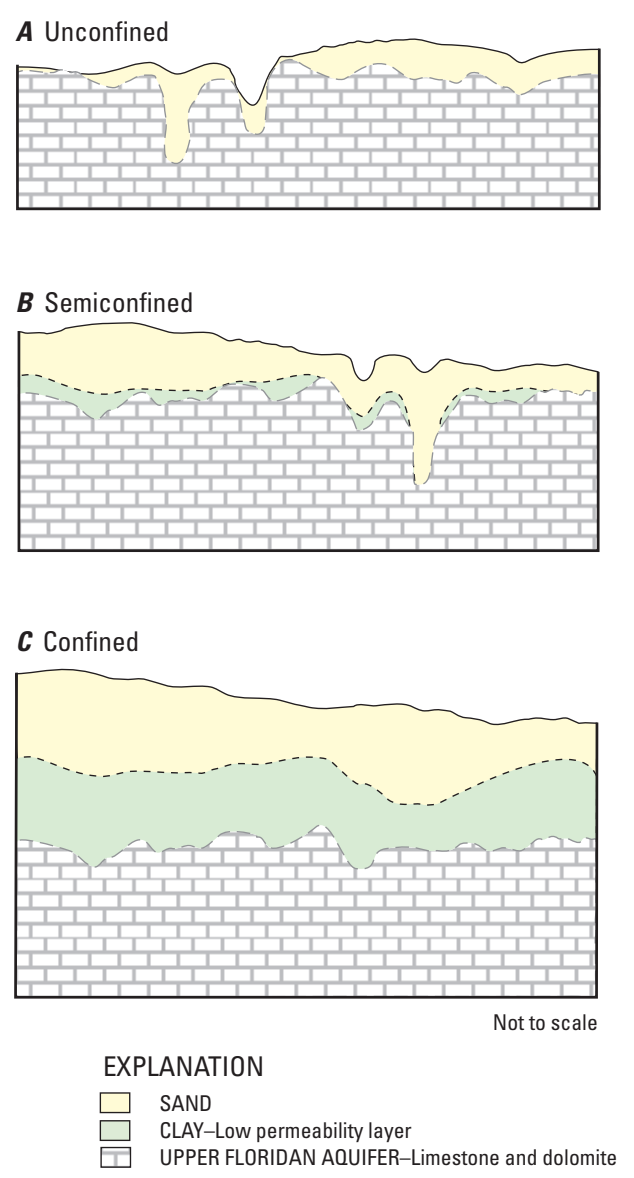

Figure 3. Conceptual cross sections showing the general hydrogeology in $A$, unconfined, $B$, semiconfined, and $C$, confined areas of the Upper Floridan aquifer. 


\section{Land Use, Population, and Water Use}

Forest, wetland, and agricultural areas constitute the majority of the land overlying the Floridan aquifer system (fig. 4). The land area overlying the Floridan aquifer system is 34-percent forest, 25-percent wetland, 20-percent agricultural, 7-percent urban, 5-percent rock quarry or transitional, 5-percent grassland/herbaceous, and 4-percent water (T.L. Arnold, U.S. Geological Survey, written commun., 2006). The highly populated areas relying on the Floridan aquifer system are located in northern and coastal parts of Florida and in the coastal parts of Georgia (fig. 5), and include the major cities of Gainesville, Jacksonville, Orlando, St.

Petersburg, Tallahassee, and Tampa, Florida, and Savannah, Georgia (figs. 1 and 5).

An estimated 4,020 Mgal/d (15,230,000 m³ $/ \mathrm{d})$ of water was withdrawn from the Floridan aquifer system in 2000 (Marella and Berndt, 2005) with the highest use occurring in the most densely populated areas along the eastern coast and central Florida (fig. 6). The greatest withdrawals occurred in Florida (3,125 Mgal/d; 11,840,000 m³ d), whereas lesser amounts were withdrawn in Georgia $(825 \mathrm{Mgal} / \mathrm{d}$; $3,120,000 \mathrm{~m}^{3} / \mathrm{d}$ ), South Carolina (63 Mgal/d; 240,000 m³/d), and Alabama (7 Mgal/d; 27,000 m³/d) (Marella and Berndt, 2005). About 90 percent of the water withdrawn from the

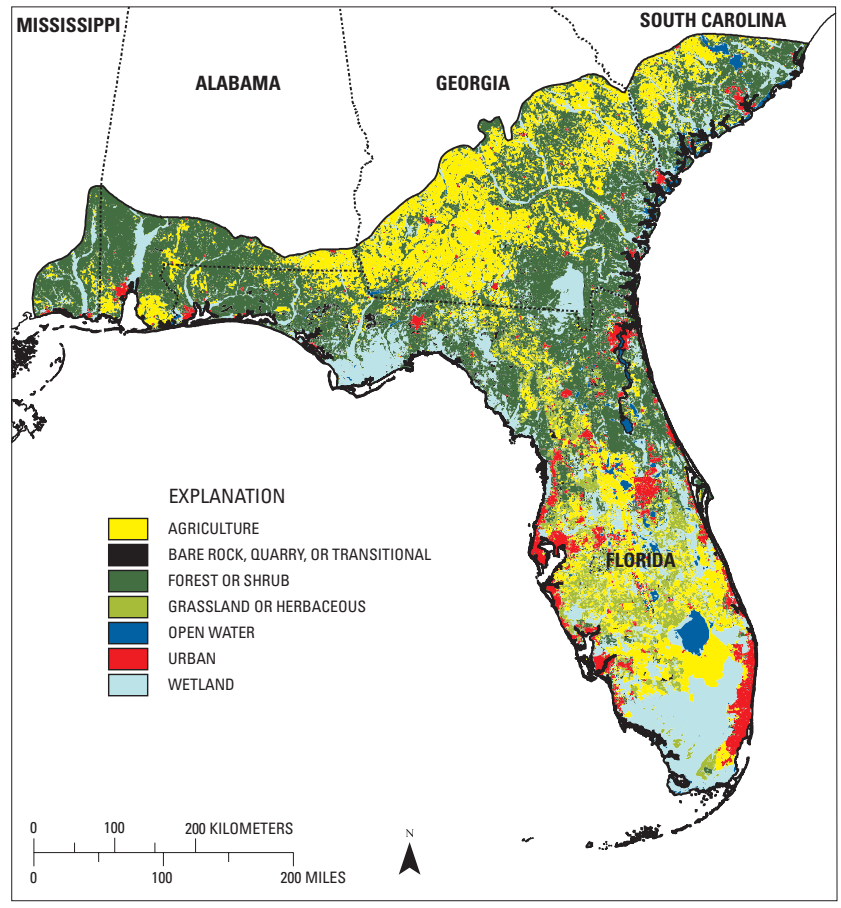

Figure 4. Generalized land use and land cover overlying the Floridan aquifer system, 1992-98. (Data from T.L. Armold, U.S. Geological Survey, 2006, written commun.)
Floridan aquifer system was obtained from the Upper Floridan aquifer, which is closer to land surface and contains potable water in most areas. Irrigation $\left(1,949 \mathrm{Mgal} / \mathrm{d} ; 7,383,000 \mathrm{~m}^{3} / \mathrm{d}\right)$ and public supply $\left(1,329 \mathrm{Mgal} / \mathrm{d} ; 5,034,000 \mathrm{~m}^{3} / \mathrm{d}\right)$ were the two largest categories of withdrawal from the Floridan aquifer system, with lesser amounts withdrawn for industrial (576 Mgal/d; 2,180,000 $\mathrm{m}^{3} / \mathrm{d}$ ) and domestic self-supplied uses (166 Mgal $\left./ \mathrm{d} ; 629,000 \mathrm{~m}^{3} / \mathrm{d}\right)$.

Withdrawals of water from the Floridan aquifer system increased by more than 500 percent between 1950 and 2000 from $630 \mathrm{Mgal} / \mathrm{d}\left(2,386,000 \mathrm{~m}^{3} / \mathrm{d}\right)$ (Bush and Johnston, 1988) to $4,020 \mathrm{Mgal} / \mathrm{d}\left(15,230,000 \mathrm{~m}^{3} / \mathrm{d}\right)$ (Marella and Berndt, 2005). The increase in withdrawals is attributed to increases in population, tourism, and agricultural production throughout the southeastern United States. Withdrawals for irrigation accounted for nearly half of the increase - irrigation withdrawals increased from $90 \mathrm{Mgal} / \mathrm{d}\left(340,000 \mathrm{~m}^{3} / \mathrm{d}\right)$ in 1950 to $1,950 \mathrm{Mgal} / \mathrm{d}\left(7,386,000 \mathrm{~m}^{3} / \mathrm{d}\right)$ in 2000 . Withdrawals for public supply increased from $85 \mathrm{Mgal} / \mathrm{d}\left(320,000 \mathrm{~m}^{3} / \mathrm{d}\right)$ in 1950 to $1,330 \mathrm{Mgal} / \mathrm{d}\left(5,038,000 \mathrm{~m}^{3} / \mathrm{d}\right)$ in 2000 . The population served by public supply increased from 4.5 million people in 1980 to 8.2 million in 2000. The number of domestic wells within Florida increased 23 percent between 1990 and 2000 (Marella, 2004).

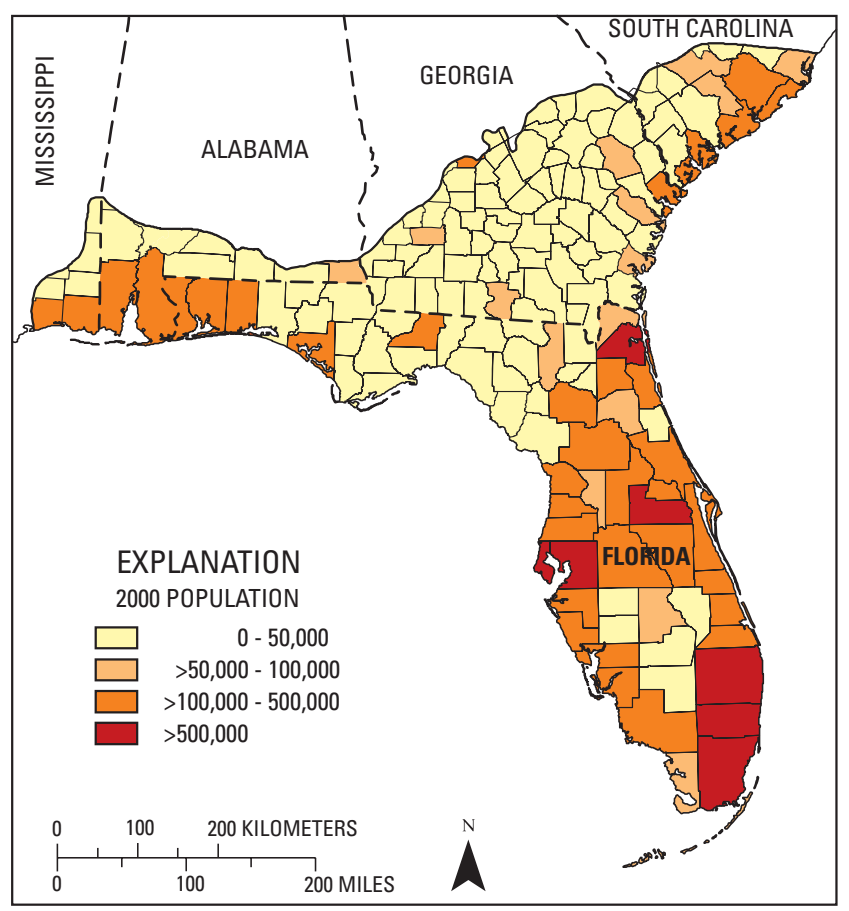

Figure 5. Population by county in areas overlying the Floridan aquifer system, 2000. (Data from U.S. Bureau of the Census, 2000a.) 


\section{Methods}

The following sections describe the methods used to collect and analyze data for this report. Methods described include sample collection and processing, quality assurance and quality control, comparison of results to water-quality benchmarks for human health, compilation of ancillary data about sampling sites, and geochemical and statistical analysis methods.

\section{Sample Collection and Processing}

Water samples were collected and processed using methods designed to yield samples that were representative of environmental conditions, minimally affected by contamination (Koterba and others, 1995). The samples were collected directly from the wells before any water treatment and, in most instances, before any pressure or holding tanks. Field measurements were made of $\mathrm{pH}$, specific conductance, temperature, alkalinity, and dissolved oxygen.

Samples were collected for laboratory analysis of major ions, nutrients, dissolved organic carbon, trace elements, radon, volatile organic compounds (VOCs), and pesticides. Water samples were analyzed at the USGS National Water

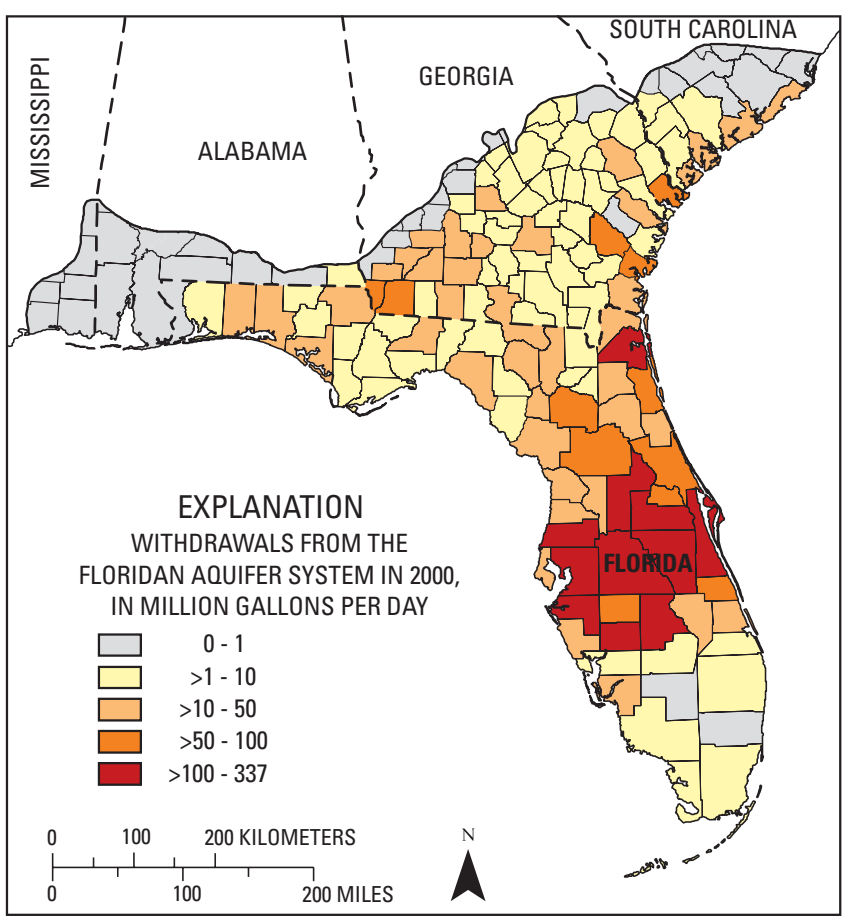

Figure 6. Water withdrawals by county from the Floridan aquifer system, 2000. (Data from Marella and Berndt, 2005.)
Quality Laboratory (NWQL) in Lakewood, Colorado. VOC and pesticide analytes are listed in Appendixes 1 and 2, respectively.

\section{Quality Assurance and Quality Control}

Procedures to ensure data quality include written protocols for collection of field and laboratory quality-control samples. Quality-control samples were collected to provide information on possible sample contamination and measurement variability associated with the data-collection process (Koterba and others, 1995). These quality-control samples consisted of field blank and sequential replicate samples that were collected, processed, and analyzed using methods similar to those used for the environmental samples. Field blanks were collected to ensure that equipment was adequately cleaned during sample collection to minimize potential cross contamination and that collection and processing did not result in contamination. Sequential replicate samples were collected immediately after environmental samples were collected, using the same equipment. Comparison of the results for the replicate sample to the results for the environmental sample aids in determining the variability of chemical analyses and the consistency of sample collection and processing.

The examination of VOC detections in field blanks, without comparison to the subsequently collected groundwater samples, overstates the potential for random contamination (associated with field protocols) in subsequently collected groundwater samples for some VOCs (J.S. Zogorski, U.S. Geological Survey, written commun., 2008). The water used to process field blanks (blank water) occasionally contains some VOCs, and the analytical results for field blanks can reflect this contamination source. Field blank contamination is most often (but not always) reduced to non-detectable levels prior to collection of a groundwater sample, thus eliminating this contamination source in most groundwater samples. The additional rinsing of the equipment and sample lines with well water prior to the collection of a groundwater sample is the probable cause for the elimination of contaminants. This native water rinsing has been shown to be highly effective in reducing the potential carryover of contaminants from equipment and sample lines to groundwater samples (Taglioli and others, 2001). For these reasons, examination of VOC detections in field blanks, without comparison to the subsequently collected groundwater samples, is considered inadequate to describe the extent of random contamination of groundwater samples.

Analysis of NAWQA data from paired blank and groundwater samples during the collection of water samples from domestic and public-supply wells (during 1997-2008) indicates that only two VOCs require an assessment level to address potential random contamination associated with the method of collection for groundwater samples. 
The recommended interim assessment levels are 0.03 $\mu \mathrm{g} / \mathrm{L}$ (micrograms per liter) for toluene and $0.05 \mu \mathrm{g} / \mathrm{L}$ for 1,2,4-trimethylbenzene (J.S. Zogorski, U.S. Geological Survey, written commun., 2008). At these concentrations, the maximum probability of contamination in groundwater samples due to random sample contamination is about 1 percent for both compounds (J.S. Zogorski, U.S. Geological Survey, written commun., 2008). Detections of toluene and 1,2,4-trimethylbenzene below these recommended levels were treated as non-detections.

\section{Water-Quality Benchmarks for Human Health}

Concentrations of water-quality constituents are compared to drinking water MCLs and Secondary Maximum Contaminant Levels (SMCLs) for regulated compounds (U.S. Environmental Protection Agency, 2006), and to USGS HBSLs concentrations for unregulated compounds. These HBSLs are estimates of benchmark concentrations used to evaluate water-quality data in a human-health context and were developed collaboratively by the USGS, USEPA, New Jersey Department of Environmental Protection, and Oregon Health \& Science University (Toccalino and others, 2003; 2004). Although HBSLs are not regulatory standards and are not enforceable, they can be used as planning tools to prioritize contaminants that merit further study or monitoring. These HBSLs can provide an early indication of contaminant concentrations before they reach the level of human-health concern in water resources (Toccalino and others, 2005). In this study, measured concentrations were compared to their respective benchmark concentration by calculating a benchmark quotient value to identify compounds of potential human-health concern. The benchmark quotient value is the ratio of a measured concentration of a detected compound to its MCL (for a regulated compound) or HBSL (for an unregulated compound). A benchmark quotient value greater than or equal to 1.0 was used to identify concentrations of potential human-health concern. A benchmark quotient value greater than or equal to 0.1 was used to identify compounds that may warrant inclusion in a low-concentration, trends-monitoring program. Such monitoring may provide an early indication of contaminant levels that approach human-health benchmarks, and consequently, concentrations of potential concern.

\section{Geochemical Analysis}

The geochemical program Aquachem was used to determine major-ion water types by converting concentrations of major ions into equivalents per liter (Waterloo Hydrogeologic Inc., 2005). This computer program was also used to construct Piper diagrams that show the relative amounts of cations and anions in each water sample. The computer program PHREEQCI was used to determine calcite and dolomite saturation indices (Charlton and Parkhurst, 2002; Parkhurst and Appelo, 1999).

\section{Statistical Analysis}

Descriptive and nonparametric statistics were used to summarize and compare well depth and concentrations of field properties, major ions and trace elements, nitrate, and dissolved organic carbon. The nonparametric Spearman rank correlation test was used to test for correlation between well depth and concentrations of major ions and field parameters within a group of data. The nonparametric Wilcoxon rank-sum test was used to test for differences in values or concentrations between two groups of data (SAS Institute, Inc., 1989a; 1989b; Helsel and Hirsch, 1992). The alpha value used for these tests was 0.05 , which means there is a 95-percent confidence that the differences among groups are not due to random chance. The p-value from the statistical tests must be less than the alpha value of 0.05 for the differences to be significant.

Table 1. Classification strategy for the dominant land use in the 500-meter-radius area surrounding each domestic well site in the Upper Floridan aquifer.

[Land-use data described in Vogelmann and others, 2001, and Nakagaki and Wolock, 2005; land-use categorization based on Gilliom and others, 2006]

\begin{tabular}{ll}
\hline \multicolumn{1}{c}{ Land-use classification } & \multicolumn{1}{c}{ Buffer area land-use criteria } \\
\hline Agricultural & $>50$ percent agricultural land and $\leq 5$ percent urban land \\
Urban & $>25$ percent urban land and $\leq 25$ percent agricultural land \\
Undeveloped & $\leq 5$ percent urban land and $\leq 25$ percent agricultural land \\
Mixed & All other combinations of urban, agricultural, and undeveloped land \\
\hline
\end{tabular}


The nonparametric Peto-Prentice test and multiple comparison procedures (Helsel, 2005) were used to determine if differences in median concentrations of nitrate were statistically significant between the samples in the three confinement categories and five sampling networks. The Peto-Prentice test was designed to handle data censored at multiple reporting levels and was used for the nitrate data because about half of the 148 samples had nitrate concentrations less than analytical reporting levels of either 0.06 or $0.05 \mathrm{mg} / \mathrm{L}$. The multiple comparison procedures included a series of individual comparisons between two groups at a time. For each individual comparison of two groups, the alpha value of 0.05 was divided by the number of groups to obtain an individual comparison level (Helsel, 2005). Thus, for each pair-wise comparison among the three confinement categories (such as comparison of confined to unconfined), the alpha value of 0.05 is divided by 3 , and the p-value must be less than 0.017 for the differences to be significant, For each pair-wise comparison among the five sampling networks, the alpha value of 0.05 is divided by 5 , and the $p$-value must be below 0.010 for the differences to be significant (Helsel, 2005).

The Kendall's tau test for censored data (Helsel, 2005) was used to assess the significance of correlations between nitrate concentration and selected factors such as land use, nitrogen sources, population density, and soil characteristics. This nonparametric method uses ranks of the data to determine a monotonic relation between the explanatory variable (or factor) and the response variable (nitrate concentration). A p-value less than 0.05 indicates a 95-percent confidence level that a monotonic relation exists between the explanatory variable and the response variable.

\section{Compilation of Ancillary Data}

Ancillary data used in this report are derived from ancillary spatial-data layers that were developed to characterize NAWQA sampling sites for national synthesis of waterquality data. Estimates were generated for percentages of land within major land-use categories, population density, septic tank density, nitrogen and pesticide inputs, and soil properties for a 500-m-radius area surrounding wells sampled as part of the NAWQA Program (K.J. Hitt, U.S. Geological Survey, written commun., 2006). Although, the 500-m-radius area is not intended to represent the contributing area to the well, the information for this area does provide information about land use and potential sources of contamination near the sampled well. The national and county level estimates were compiled by various authors (listed below). Estimates for each data source were then computed for the 500-m-radius area (K.J. Hitt, U.S. Geological Survey, written commun., 2006).
Land-use data, population density, septic tank density, nitrogen and pesticide inputs, and soil properties were derived from several sources. The land-use data set was derived from an enhanced version of the USGS 1992 National Land Cover Data (NLCD) (Vogelmann and others, 2001; Price and others, 2007). For population density, the data set consists of 1990 Census of Population and Housing data, which includes 1990 population density, percentage of housing units using domestic wells, and percentage of housing units with septic tanks (U.S. Bureau of the Census 1991; 2000a). Estimates of atmospheric deposition of nitrogen, nitrogen from manure, and nitrogen from fertilizer were obtained from Ruddy and others (2006). Estimates of nitrogen from septic systems were made by using census data and equation (1) (Lindsey and others, 2009):

\begin{tabular}{|c|c|}
\hline $\begin{array}{l}\text { N-Septic }= \\
\text { where }\end{array}$ & $\begin{array}{l}\mathrm{DENS} \times(\mathrm{SEWSEP} / 100) \times 0.785 \mathrm{~km}^{2} \\
\times 6.72 \mathrm{lb} / \mathrm{yr} \times 0.454 \mathrm{~kg} / \mathrm{lb},\end{array}$ \\
\hline N-Septic & $\begin{array}{l}=\text { the estimated nitrogen input from septic } \\
\text { systems, in kilograms per year. }\end{array}$ \\
\hline POPDENS & $\begin{aligned}= & \text { the } 1990 \text { population density in the } 500-\mathrm{m} \\
& \text { radius, in people per square kilometer } \\
& \text { (U.S. Bureau of Census, } 1990 ; 1991 \text { ) }\end{aligned}$ \\
\hline SEWSEP & $\begin{aligned}= & \text { the percent of the housing units on septic } \\
& \text { systems (U.S. Bureau of Census, 1992) }\end{aligned}$ \\
\hline $0.785 \mathrm{~km}^{2}$ & $\begin{aligned}= & \text { the area of the 500-m radius surrounding } \\
& \text { each well }\end{aligned}$ \\
\hline $6.72 \mathrm{lb} / \mathrm{yr}$ & $\begin{array}{l}=\text { the estimated mass of nitrogen per } \\
\text { person introduced to a septic system } \\
\text { (U.S. Environmental Protection Agency, } \\
\text { 2002), and }\end{array}$ \\
\hline & $=$ the conversion from pounds to kilogram \\
\hline
\end{tabular}

Estimates of pesticide application amounts for atrazine and metolachlor applications were compiled by Nakagaki and Wolock (2005). Soils data were obtained from the State Soil Geographic (STATSGO) Data Base (U.S. Department of Agriculture, 1994) and compiled by Wolock (1997).

STATSGO includes characteristics such as permeability, organic-matter content, particle size, and hydrologic groups. Hydrologic groups are ordered from A to D, with group A having the lowest runoff potential and group $\mathrm{D}$ having the highest runoff potential (U.S. Department of Agriculture, 2007).

A land-use classification was assigned to each well based on the percentages of selected land-use categories in the 500-m-radius areas. Sites were assigned a land-use classification of agricultural, urban, undeveloped or mixed using the classification system described in table 1. Results were used to compare the median nitrate concentrations and the occurrence of VOCs and pesticides among the land-use classifications. 


\section{Characteristics of Sampling Networks}

Samples were collected from 148 domestic wells in Florida, Georgia, South Carolina, and Alabama as part of a NAWQA regional assessment of water quality in the Floridan aquifer system. Wells tapping the Upper Floridan aquifer were sampled in networks of 28 to 30 wells from 1998 to 2005. Wells were selected to represent groundwater being utilized for drinking water or other domestic uses. Most wells sampled are used by individual homeowners, but a few are used by small groups of homes, churches, or other small communities. Samples were collected in 1998 from 30 wells in semiconfined areas in southern South Carolina (network santsus2); in 2002 from 28 wells in unconfined areas in southwestern Georgia (acfbsus1), 30 wells in unconfined areas in northern Florida (gaflsus2), and semiconfined areas in northern Florida (gaflsus3); and in 2005 from 30 wells in confined areas in southeastern Georgia (gaflsus4) (table 2; fig. 2). It should be noted that the network in the unconfined area in southwestern Georgia includes 2 wells in Alabama and 3 wells in Florida; the network in the semiconfined area in northern Florida includes 2 wells in Georgia; and the network in the confined area in southeastern Georgia includes 4 wells in Florida.

Well depths were variable among the sampling networks with the deepest wells in confined areas of the Upper Floridan aquifer (fig. 7). Median well depths were $50 \mathrm{~m}$ or less for the four networks in unconfined and semiconfined areas and ranged from a median depth of $28.0 \mathrm{~m}$ for wells in the network in unconfined areas in northern Florida (gaflsus2) to $53.3 \mathrm{~m}$ for wells in the semiconfined area in southern South Carolina (santsus2). The median depth for wells in the network in the confined area in southeastern Georgia (gaflsus4) was $132 \mathrm{~m}$.

Selected characteristics of the areas surrounding the sampled wells, including potential contaminant sources such as land use, nitrogen sources, and population density were compiled to use as variables to explain water-quality results. In addition to potential sources of contaminants, soil properties were compiled for the areas surrounding the sampled wells because these data are related to transport of contaminants through the aquifer. Estimated values for these source and transport factors for the areas surrounding each sampled well were used in the analysis of the contaminant occurrence in groundwater. Median values for these source and transport factors are given for the entire data set and the five sampling networks in table 3 and are discussed in subsequent paragraphs.

Agricultural and urban land uses provide potential sources of contaminants. For the entire data set, the median percentage of agricultural land use in areas surrounding wells was 40.6 percent (table 3 ). The median percentage of agricultural land use was greater than 50 percent for three of the
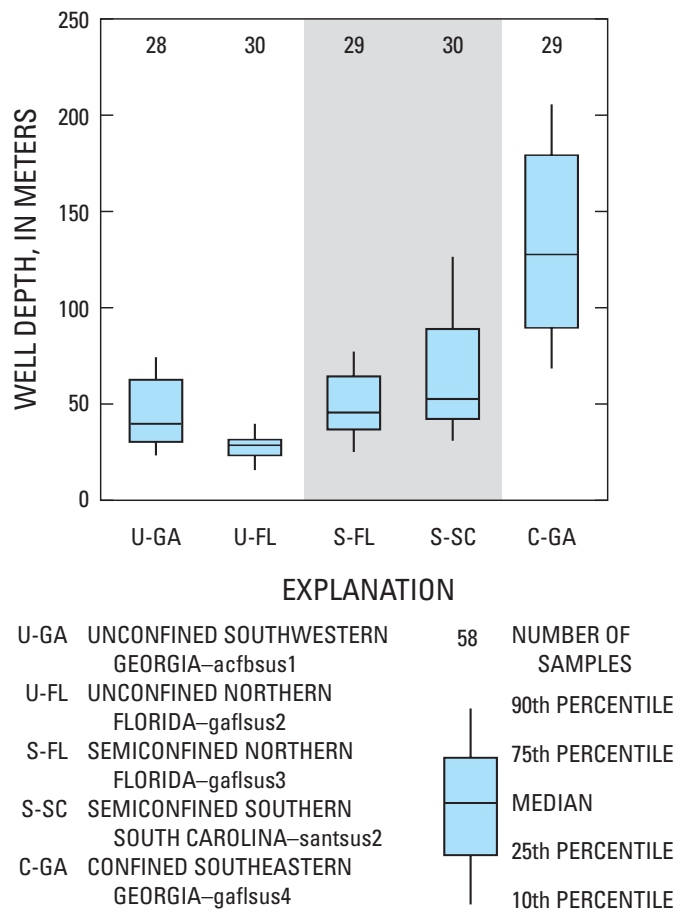

Figure 7. Boxplot showing distribution of depths of domestic wells by sampling network.

Table 2. Description of sampling networks of domestic wells in the Upper Floridan aquifer.

\begin{tabular}{lllccc}
\hline \multicolumn{1}{c}{$\begin{array}{c}\text { Upper Floridan aquifer } \\
\text { confinement category }\end{array}$} & \multicolumn{1}{c}{ Network } & $\begin{array}{c}\text { Number } \\
\text { of wells }\end{array}$ & $\begin{array}{c}\text { Year } \\
\text { sampled }\end{array}$ & $\begin{array}{c}\text { Network } \\
\text { code }\end{array}$ & $\begin{array}{c}\text { National Water-Quality } \\
\text { Assessment (NAWOA) code }\end{array}$ \\
\hline Unconfined & $\begin{array}{c}\text { Southwestern } \\
\text { Georgia }\end{array}$ & 28 & 2002 & U-GA & acfbsus1 \\
Unconfined & Northern Florida & 30 & 2002 & U-FL & gaflsus2 \\
Semiconfined & Northern Florida & 30 & 2002 & S-FL & gaflsus3 \\
Semiconfined & $\begin{array}{l}\text { Southern } \\
\text { South Carolina }\end{array}$ & 30 & 1998 & S-SC & santsus2 \\
Confined & $\begin{array}{c}\text { Southeastern } \\
\text { Georgia }\end{array}$ & 30 & 2005 & C-GA & gaflsus4 \\
\hline
\end{tabular}

\footnotetext{
${ }^{1}$ Network includes some wells in southeastern Alabama.
}

${ }^{2}$ Network includes some wells in central Georgia and northern Florida. 


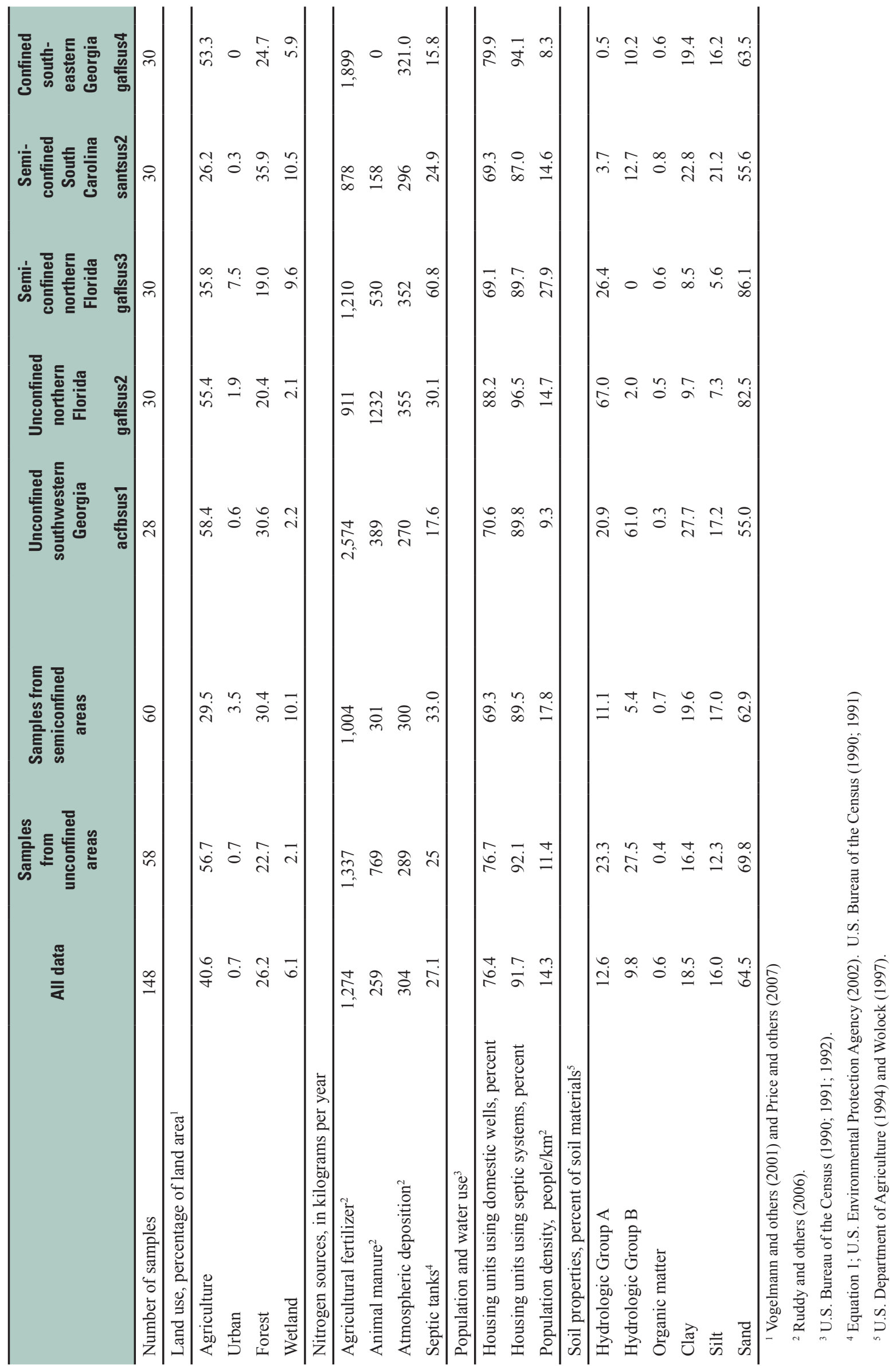


sampling networks - the networks in the unconfined areas in southwestern Georgia (acfbsus1) and northern Florida (gaflsus2), and the network in the confined area in southeastern Georgia (gaflsus4). For the entire data set, the median percentage of urban land use was 0.7 percent. The median percentage of urban land use was highest (7.5 percent) in the network in the semiconfined area in northern Florida. The median percentage of urban land use was less than 1 percent in three of the sampling networks. The median percentage of forest land use was highest in the network in the semiconfined area in southern South Carolina (35.9 percent). The median percentage of land area in wetlands was highest (10.5 percent) in the network in the semiconfined area in southern South Carolina (table 3).

Population density and water use by household showed that most housing units used domestic wells and had a septic tank system. The median percentage of housing units using domestic wells ranged from about 70 to 88 percent, and the median percentage of housing units with septic tanks ranged from about 87 to 96 percent (table 3). The median population density in 1990 varied from about 8 people per square kilometer (people $/ \mathrm{km}^{2}$ ) in the network in the confined area in southeastern Georgia (gaflsus4) to about 28 people $/ \mathrm{km}^{2}$ for the network in the semiconfined area in northern Florida (gaflsus3).

Nitrogen associated with agricultural land-use sources comprised the largest component of the potential sources of nitrogen. The median amount of nitrogen from agricultural fertilizer was 1,274 kg/yr (kilogram per year) for the entire data set, and median values for sampling networks ranged from about $878 \mathrm{~kg} / \mathrm{yr}$ in the semiconfined area in southern South Carolina to $2,574 \mathrm{~kg} / \mathrm{yr}$ in the unconfined area in southwestern Georgia (table 3). The median amount of nitrogen from animal manure was $259 \mathrm{~kg} / \mathrm{yr}$ for the entire data set, and median values for sampling networks ranged from $0 \mathrm{~kg} / \mathrm{yr}$ in the confined area in southeastern Georgia to $1,232 \mathrm{~kg} / \mathrm{yr}$ in the unconfined area in northern Florida. The median amounts of nitrogen from atmospheric deposition and septic tanks were much lower ranging from 270 to $355 \mathrm{~kg} / \mathrm{yr}$ for atmospheric deposition and 15.8 to $60.8 \mathrm{~kg} / \mathrm{yr}$ for septic tanks.

For the soil characteristics, sampling networks in the unconfined areas in northern Florida and southwestern Georgia had the highest percentage of soils in soil hydrologic groups A and B (the two categories comprising well drained and moderately well drained soils) (U.S. Department of Agriculture, 2007). Other networks had less than 27 percent of soils in either of these two categories. The percentage of soil materials comprised of organic matter was low, with median values ranging from 0.3 to 0.8 percent. The percentage of soil materials comprised of clay ranged from about 8 to 28 percent, and the percentage comprised of silt ranged from about 7 to 21 percent. The percentage of soil materials comprised of sand showed the greatest variability among the sampling networks, ranging from about 55 to 86 percent (table 3), with the highest median percentages occurring in the networks in the unconfined and semiconfined areas in northern Florida.

\section{Groundwater Geochemistry}

The dissolution of aquifer minerals, such as calcite and dolomite in carbonate aquifers, is an important geochemical process that controls the major-ion composition and $\mathrm{pH}$ of groundwater. Examination of $\mathrm{pH}$ values and concentrations of dissolved solids, major ions, and dissolved oxygen spatially and with depth in the aquifer can provide a means to assess the importance of groundwater residence time as a controlling factor on major-ion geochemistry. Few health guidelines have been established for major ions, but a MCL of $4 \mathrm{mg} / \mathrm{L}$ has been established for fluoride. The SMCLs have been established for $\mathrm{pH}$, dissolved solids, chloride, sulfate and fluoride (U.S. Environmental Protection Agency, 2006). Analysis of dissolved oxygen concentrations in groundwater aid in determining the oxidation and reduction (redox) reactions that serve an important role in the transformation and biodegradation of anthropogenic compounds such as nitrate, pesticides, and VOCs. Assessment of major-ion water types and ion ratios can provide quantitative information about mineral-water interactions. In addition, determination of saturation indices with respect to calcite and dolomite using thermodynamic models is useful to gain an improved understanding of the factors that influence groundwater geochemistry (Stumm and Morgan, 1981).

\section{Dissolved Solids, Dissolved Oxygen, Major lons, and pH}

Concentrations of dissolved solids, dissolved oxygen, major ions, and values of $\mathrm{pH}$ were assessed for the 148 samples collected from domestic wells (table 4). Dissolved solids concentrations ranged from 91 to $5,370 \mathrm{mg} / \mathrm{L}$, with a median concentration of $179 \mathrm{mg} / \mathrm{L}$ (fig. 8). Concentrations of dissolved oxygen ranged from 0.1 to $9.7 \mathrm{mg} / \mathrm{L}$ with a median concentration of $0.7 \mathrm{mg} / \mathrm{L}$. Calcium concentrations ranged from 1.5 to $302 \mathrm{mg} / \mathrm{L}$ and magnesium concentrations ranged from 0.35 to $90.6 \mathrm{mg} / \mathrm{L}$. Median calcium and magnesium concentrations were 42.3 and $4.67 \mathrm{mg} / \mathrm{L}$, respectively. The median bicarbonate concentration was $154 \mathrm{mg} / \mathrm{L}$, and concentrations ranged from 54 to $567 \mathrm{mg} / \mathrm{L}$. Sulfate concentrations ranged from 0.7 to $858 \mathrm{mg} / \mathrm{L}$, with a median concentration of $3.4 \mathrm{mg} / \mathrm{L}$, chloride concentrations ranged from 2.21 to $2,580 \mathrm{mg} / \mathrm{L}$ with a median concentration of $5.47 \mathrm{mg} / \mathrm{L}$, and fluoride concentrations ranged from 0.1 to $5.5 \mathrm{mg} / \mathrm{L}$ with a median concentration of $0.17 \mathrm{mg} / \mathrm{L}$. The median $\mathrm{pH}$ was 7.5 , and $\mathrm{pH}$ values ranged from 6.3 to 9.0 .

Median concentrations of dissolved solids, several major ions, and dissolved oxygen varied between sampling networks based on confinement categories for the Upper Floridan aquifer, although values of $\mathrm{pH}$ varied little between sampling networks (table 5). The median dissolved solids concentrations ranged from $147 \mathrm{mg} / \mathrm{L}$ for the unconfined area in southwestern Georgia to $235 \mathrm{mg} / \mathrm{L}$ for the semiconfined 
Table 4. Summary statistics of well depth, temperature, $\mathrm{pH}$, major ions, and selected chemical constituents in domestic wells in the Upper Floridan aquifer.

[Concentrations in milligrams per liter, except as noted; $\mu \mathrm{S} / \mathrm{cm}$, microsiemens per centimeter]

\begin{tabular}{lcccccc}
\hline \multicolumn{1}{c}{ Variable } & $\begin{array}{c}\text { Number of } \\
\text { observations }\end{array}$ & Median & Minimum & $\begin{array}{c}\text { 25th } \\
\text { Percen- } \\
\text { tile }\end{array}$ & $\begin{array}{c}\text { 75th } \\
\text { Percentile }\end{array}$ & Maximum \\
\hline Well depth, meters & 145 & 144.5 & 6.1 & 25.6 & 79.2 & 244 \\
Temperature, degrees Celsius & 148 & 22.4 & 13.5 & 20.6 & 24.0 & 29.9 \\
Specific conductance, $\mu$ S/cm & 148 & 291 & 141 & 244 & 374 & 9,180 \\
Dissolved solids & 148 & 179 & 91 & 146 & 229 & 5,370 \\
Dissolved oxygen & 147 & 0.7 & 0.1 & 0.2 & 4.1 & 9.7 \\
pH, standard units & 148 & 7.5 & 6.3 & 7.3 & 7.7 & 9.0 \\
Bicarbonate & 148 & 154 & 54 & 132 & 195 & 567 \\
Calcium & 148 & 42.3 & 1.5 & 31.5 & 56.3 & 302 \\
Magnesium & 148 & 4.67 & 0.35 & 1.43 & 10.6 & 90.6 \\
Sodium & 148 & 4.50 & 1.36 & 2.56 & 11.0 & 1,760 \\
Potassium & 148 & .73 & .06 & .34 & 1.97 & 59.4 \\
Sulfate & 148 & 3.4 & 1 & .7 & 8.0 & 858 \\
Chloride & 148 & 5.47 & 2.21 & 3.88 & 8.99 & 2,580 \\
Silica, as SiO ${ }_{2}$ & 148 & 12.8 & 3.58 & 7.49 & 30.5 & 65.1 \\
Fluoride & 148 & 0.17 & .1 & .1 & .32 & 5.52 \\
Bromide & 138 & .03 & .01 & .02 & .07 & 9.50 \\
Organic carbon & 148 & .40 & .16 & .29 & .99 & 17.1 \\
\hline
\end{tabular}

area in South Carolina. Median bicarbonate concentrations were lowest in the unconfined area in southwestern Georgia $(133 \mathrm{mg} / \mathrm{L})$ and highest in the semiconfined area in South Carolina and the unconfined area in northern Florida (about $190 \mathrm{mg} / \mathrm{L}$ in each network). The median magnesium concentration was lowest in the unconfined area in southwestern Georgia, $0.96 \mathrm{mg} / \mathrm{L}$, and was highest, $11.9 \mathrm{mg} / \mathrm{L}$, in the confined area in southeastern Georgia. Median chloride concentrations ranged from $3.97 \mathrm{mg} / \mathrm{L}$ in the unconfined area in southwestern Georgia to about $7 \mathrm{mg} / \mathrm{L}$ in the unconfined and semiconfined areas in northern Florida. Median $\mathrm{pH}$ by network ranged from 7.3 in the unconfined area in northern Florida to 7.6 in the unconfined area in southwestern Georgia and the semiconfined areas in northern Florida and South Carolina.

Effects of aquifer confinement on groundwater geochemistry are seen in the higher concentrations of dissolved oxygen in groundwater in unconfined areas compared to semiconfined or confined areas. Dissolved oxygen in groundwater originates from the atmosphere and is depleted as groundwater moves through the flow system. In the unconfined areas, water recharges more readily and moves through the aquifer quickly. This recently recharged groundwater in unconfined areas often contains more dissolved oxygen than older, deeper groundwater. Median concentrations

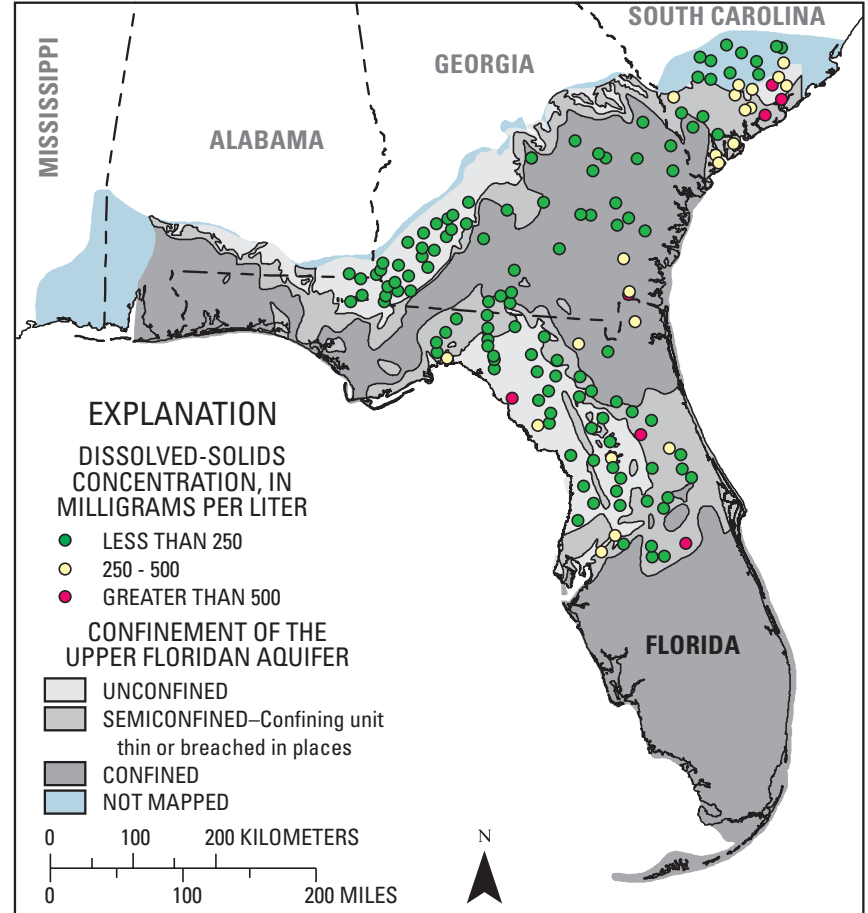

Figure 8. Spatial distribution of dissolved solids concentration in the Upper Floridan aquifer. (Modified from Miller, 1986.) 
Table 5. Summary statistics by sampling network of well depth, temperature, $\mathrm{pH}$, major ions, and selected chemical constituents in domestic wells in the Upper Floridan aquifer.

[Concentrations are expressed as milligrams per liter, except as noted]

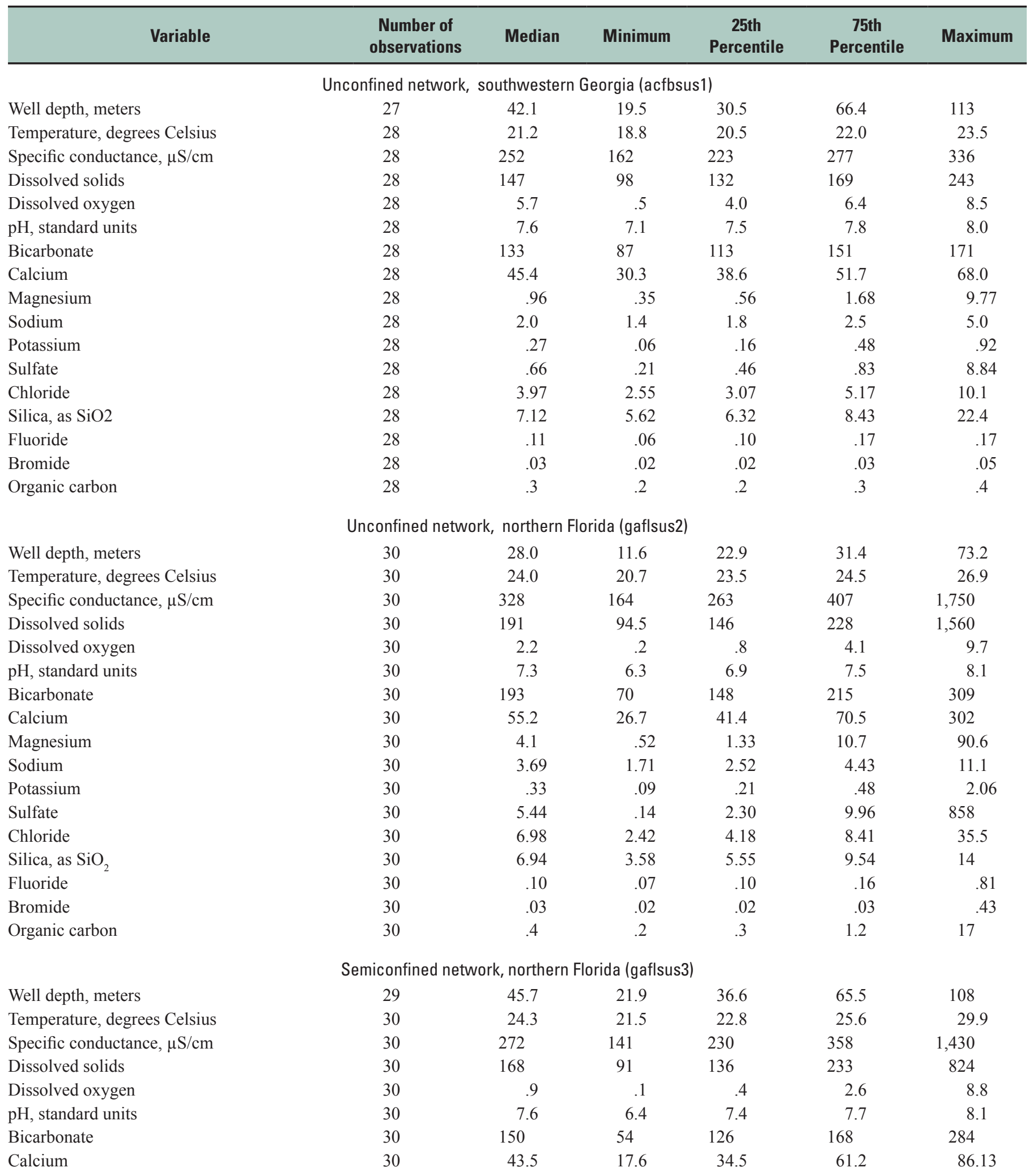


Table 5. Summary statistics by sampling network of well depth, temperature, $\mathrm{pH}$, major ions, and selected chemical constituents in domestic wells in the Upper Floridan aquifer-Continued

[Concentrations are expressed as milligrams per liter, except as noted]

\begin{tabular}{|c|c|c|c|c|c|c|}
\hline Variable & $\begin{array}{c}\text { Number of } \\
\text { observations }\end{array}$ & Median & Minimum & $\begin{array}{c}\text { 25th } \\
\text { Percentile }\end{array}$ & $\begin{array}{c}\text { 75th } \\
\text { Percentile }\end{array}$ & Maximum \\
\hline \multicolumn{7}{|c|}{ Semiconfined network, northern Florida (gaflsus3)—Continued } \\
\hline Sodium & 30 & 4.89 & 1.85 & 3.73 & 6.89 & 166 \\
\hline Potassium & 30 & .70 & .10 & .45 & .91 & 6.18 \\
\hline Silica, as $\mathrm{SiO}_{2}$ & 30 & 12 & 6.8 & 9.7 & 15.7 & 53.3 \\
\hline Fluoride & 30 & .2 & .1 & .1 & .2 & 1.1 \\
\hline Bromide & 30 & .03 & .02 & .02 & .05 & 1.00 \\
\hline Organic carbon & 30 & 6 & .2 & .4 & 1.1 & 4.4 \\
\hline \multicolumn{7}{|c|}{ Semiconfined network, South Carolina (santsus2) } \\
\hline Dissolved solids & 30 & 235 & 125 & 191 & 351 & 5,370 \\
\hline Dissolved oxygen & 30 & .2 & .1 & .1 & .2 & 5.9 \\
\hline $\mathrm{pH}$, standard units & 30 & 7.6 & 6.5 & 7.4 & 8.3 & 9.0 \\
\hline Bicarbonate & 30 & 193 & 59 & 161 & 288 & 567 \\
\hline Calcium & 30 & 34.9 & 1.47 & 10.8 & 49.4 & 68.3 \\
\hline Magnesium & 30 & 3.06 & .92 & 1.55 & 7.91 & 73.8 \\
\hline Sodium & 30 & 17.9 & 2.21 & 5.95 & 99.5 & 1,763 \\
\hline Potassium & 30 & 4.88 & .48 & 1.87 & 10.1 & 59.4 \\
\hline Sulfate & 30 & 3.86 & .10 & 1.24 & 7.16 & 185 \\
\hline Chloride & 30 & 5.44 & 2.57 & 3.95 & 20.24 & 2.580 \\
\hline Specific conductance, $\mu \mathrm{S} / \mathrm{cm}$ & 30 & 293 & 201 & 251.00 & 332.00 & 766.00 \\
\hline Dissolved solids & 30 & 190 & 130 & 168 & 217 & 502 \\
\hline Dissolved oxygen & 29 & .1 & .1 & .1 & .2 & 5.8 \\
\hline $\mathrm{pH}$, standard units & 30 & 7.4 & 6.8 & 7.3 & 7.5 & 7.7 \\
\hline Bicarbonate & 30 & 154 & 123 & 1,378 & 183 & 412 \\
\hline Calcium & 30 & 33.9 & 24.1 & 28.6 & 42.4 & 67.1 \\
\hline Magnesium & 30 & 11.9 & .79 & 5.28 & 14.9 & 40.2 \\
\hline Sodium & 30 & 10.7 & 1.76 & 4.05 & 17.1 & 47.6 \\
\hline Potassium & 30 & 1.81 & .44 & 1.28 & 2.35 & 5.14 \\
\hline Sulfate & 30 & 5.80 & .20 & 2.30 & 24.1 & 159 \\
\hline Chloride & 30 & 5.54 & 2.21 & 3.80 & 10.6 & 48.7 \\
\hline Silica, as $\mathrm{SiO}_{2}$ & 30 & 36.1 & 12.3 & 26.4 & 40.5 & 65.1 \\
\hline Fluoride & 30 & .40 & .1 & .2 & .6 & 1.1 \\
\hline Bromide & 19 & .13 & .11 & .12 & .15 & .27 \\
\hline Organic carbon & 30 & .3 & .2 & .2 & .7 & 9.7 \\
\hline
\end{tabular}




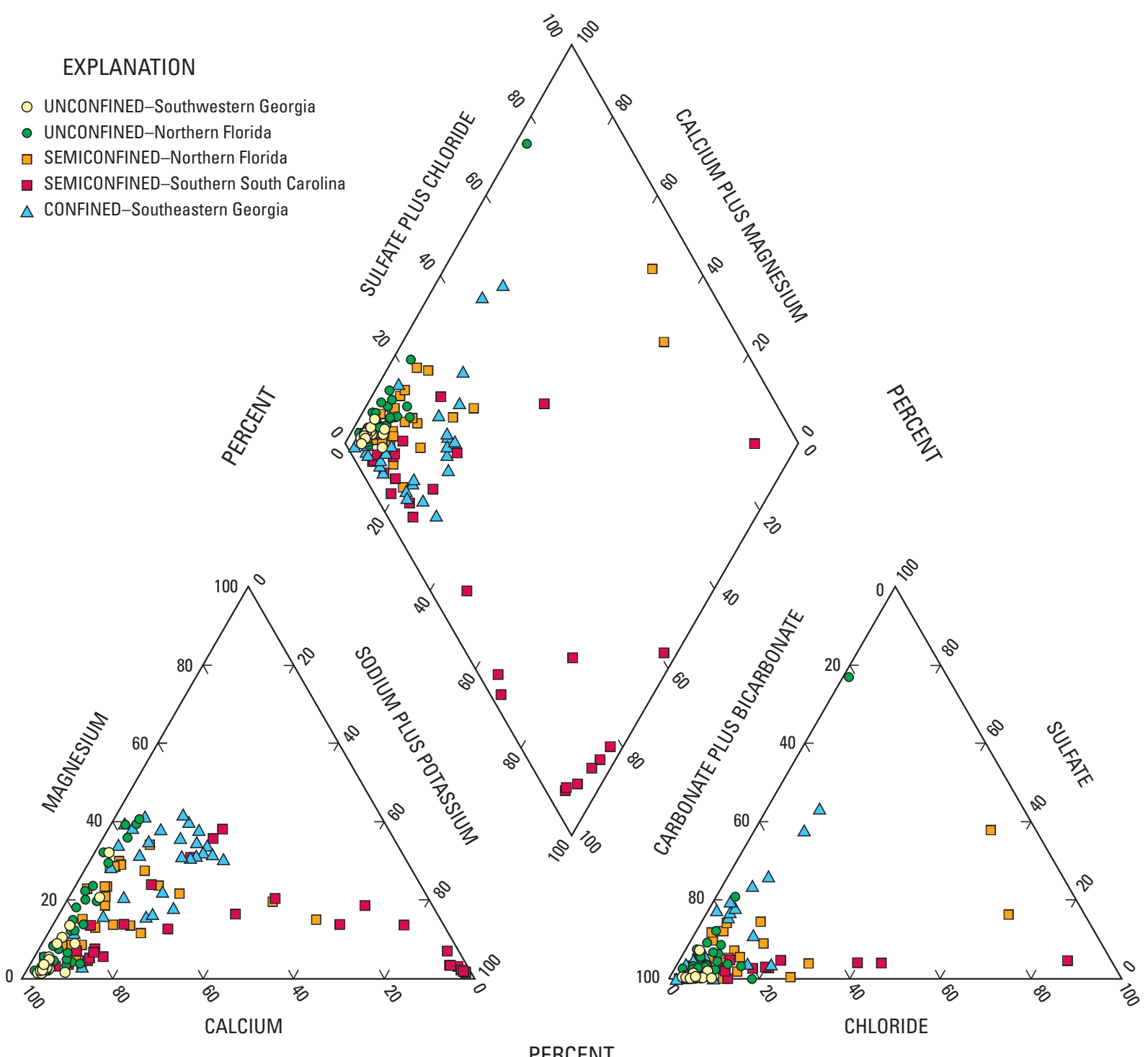

PERCENT

Figure 9. Piper diagram showing major-ion composition of water in domestic wells in the Upper Floridan aquifer.

of dissolved oxygen were highest in samples from unconfined areas in southwestern Georgia $(5.7 \mathrm{mg} / \mathrm{L})$ and northern Florida $(2.2 \mathrm{mg} / \mathrm{L})$. Median concentrations were less than $1 \mathrm{mg} / \mathrm{L}$ for samples from the three networks in semiconfined or confined areas (table 5).

Comparison of dissolved-solids and major-ion concentrations and $\mathrm{pH}$ values to MCLs or SMCLs (U.S. Environmental Protection Agency, 2006) indicated that few samples exceeded these standards for $\mathrm{pH}$, chloride, fluoride, sulfate, or dissolved solids. Fluoride is the only major ion for which an MCL has been established. Fluoride concentrations in two samples (about 1 percent of samples) exceeded the MCL of $4 \mathrm{mg} / \mathrm{L}$ (table 6). These two occurrences were in the semiconfined area in South Carolina. Dissolved-solids concentrations exceeded the SMCL of $500 \mathrm{mg} / \mathrm{L}$ in about
5 percent of wells. For $\mathrm{pH}$, about 4 percent of samples had values outside the SMCL range of 6.5 to 8.5 . The SMCLs for chloride $(250 \mathrm{mg} / \mathrm{L})$, fluoride $(4 \mathrm{mg} / \mathrm{L})$, and sulfate $(250 \mathrm{mg} / \mathrm{L})$ were exceeded in less than 3 percent of wells (table 6).

Major-ion chemistry was assessed by determining the major-ion water types based on concentrations of major ions in equivalents. Most water samples had dominant ions of calcium, bicarbonate, and magnesium (fig. 9). For the entire data set, the most commonly occurring major-ion water types were calcium-bicarbonate (57 percent of the samples) and calciummagnesium-bicarbonate (26 percent) (fig. 10). The dominant major ion water type for most samples in unconfined areas was calcium-bicarbonate (figs. 9 and 10), whereas water types for samples from networks in semiconfined and confined areas 
Table 6. Comparison of $\mathrm{pH}$ and concentrations of major ions in domestic wells in the Upper Floridan aquifer to humanhealth benchmarks and non-health guidelines for drinking water.

[All constituents in milligrams per liter, except as noted; MCLs and SMCLs are U.S. Environmental Protection Agency (USEPA) Maximum Contaminant Levels (MCLs) and Secondary Maximum Contaminant Levels (SMCLs) for public-water supplies; --, not applicable]

\begin{tabular}{|c|c|c|c|c|c|c|c|c|}
\hline \multirow[t]{3}{*}{ Constituent } & \multicolumn{4}{|c|}{ Benchmark or guideline } & \multicolumn{4}{|c|}{$\begin{array}{c}\text { Wells exceeding benchmarks } \\
\text { or guideline }\end{array}$} \\
\hline & \multicolumn{2}{|c|}{$\begin{array}{l}\text { Human-health } \\
\text { benchmark }\end{array}$} & \multicolumn{2}{|c|}{$\begin{array}{l}\text { Non-health } \\
\text { guideline }\end{array}$} & \multicolumn{2}{|c|}{$\begin{array}{l}\text { Human-health } \\
\text { benchmark }\end{array}$} & \multicolumn{2}{|c|}{$\begin{array}{l}\text { Non-health } \\
\text { guideline }\end{array}$} \\
\hline & Value & Type & Value & Type & Value & Percent & Value & Percent \\
\hline \multicolumn{9}{|c|}{ Physical properties } \\
\hline $\mathrm{pH}$, in standard units ${ }^{1}$ & -- & & $6.5-8.5$ & SMCL & -- & -- & 6 & 4.1 \\
\hline \multicolumn{9}{|c|}{ Major ions, in mg/L } \\
\hline Chloride & -- & -- & 250 & SMCL & -- & -- & 2 & 1.4 \\
\hline Fluoride & 4 & MCL & 2 & SMCL & 2 & 1.4 & 4 & 2.7 \\
\hline Sulfate & -- & -- & 250 & SMCL & -- & -- & 1 & 0.7 \\
\hline Total dissolved solids & -- & -- & 500 & SMCL & -- & -- & 7 & 4.7 \\
\hline
\end{tabular}

${ }^{1}$ Samples with $\mathrm{pH}$ less than 6.5 or $\mathrm{pH}$ greater than 8.5 exceed the SMCL.

were somewhat variable (figs. 9 and 10). For the semiconfined area in South Carolina, sodium-bicarbonate was the major-ion water type in 8 of 30 samples (fig. 10). Katz (1992) hypothesized that cation exchange is the probable cause of this water type in the Upper Floridan aquifer. Sprinkle (1989, p. 31) also reported sodium-bicarbonate waters and suggested that "the large area of apparent undersaturation in east-central Georgia may be related to local cation exchange of sodium for calcium, which reduces calcium concentration and brings groundwater below saturation with calcite." Sprinkle (1989) continued to state that another possible explanation was "that underlying Cretaceous and Tertiary sand aquifers are discharging dilute sodium-bicarbonate water into the Upper Floridan aquifer."

Molar concentrations of calcium plus magnesium were plotted against molar concentration of bicarbonate to assess whether calcite and dolomite dissolution is the major geochemical process that controls the major-ion composition. If calcite and dolomite dissolution is the dominant geochemical process, the molar concentration of bicarbonate (in millimoles per liter) should be two times the concentration of the sum of the molar concentrations of calcium and magnesium. Most water samples plot along a line with a 2:1 slope (bicarbonate to calcium plus magnesium), except for eight samples in the semiconfined area in South Carolina and a few samples in the semiconfined area in northern Florida and the confined area in southeastern Georgia (figs. 11A-C). The eight samples in South Carolina show excess bicarbonate concentrations relative to calcium and magnesium (fig. 11B). If the molar concentration of bicarbonate is plotted against the molar concentration of sodium, most of the eight samples plot on a 1:1 slope line, indicating that sodium provides the molar equivalent for the

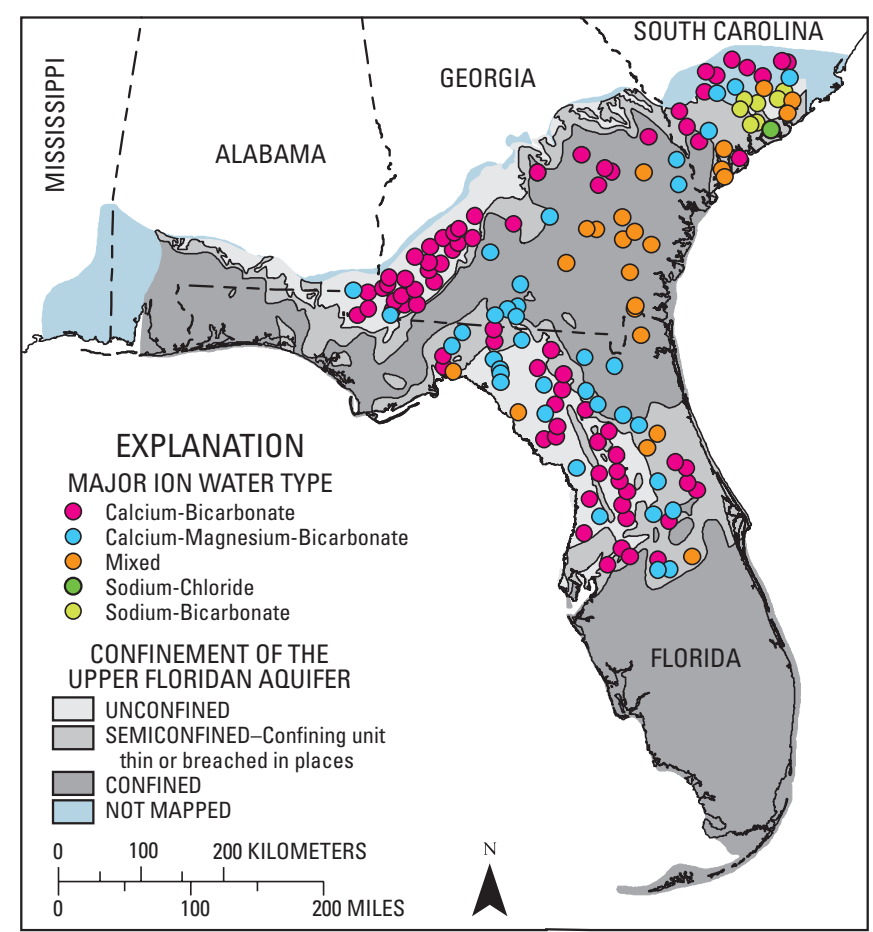

Figure 10. Spatial distribution of major-ion water types in water from domestic wells in the Upper Floridan aquifer.

excess bicarbonate in these samples (fig. 11D). Because the increase in sodium is not accompanied by an increase in chloride, cation exchange rather than saltwater is the probable the source of the sodium. 
Only one sample collected for this study had a sodium-chloride water type, indicating possible mixing of saltwater with groundwater. The sample was from the semiconfined area in South Carolina and showed other evidence of saltwater mixing, including elevated concentrations of dissolved solids $(5,370 \mathrm{mg} / \mathrm{L})$, bicarbonate $(567 \mathrm{mg} / \mathrm{L})$,
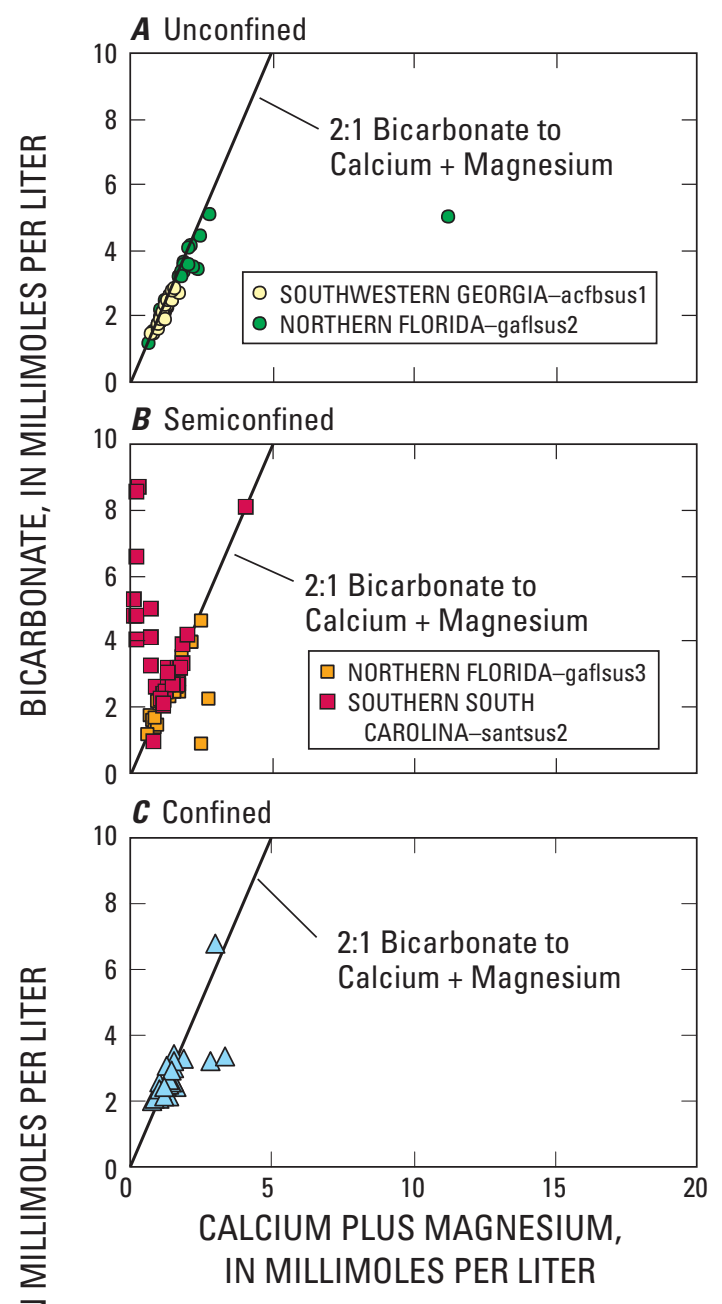

D Semiconfined--southern South Carolina (santsus2)

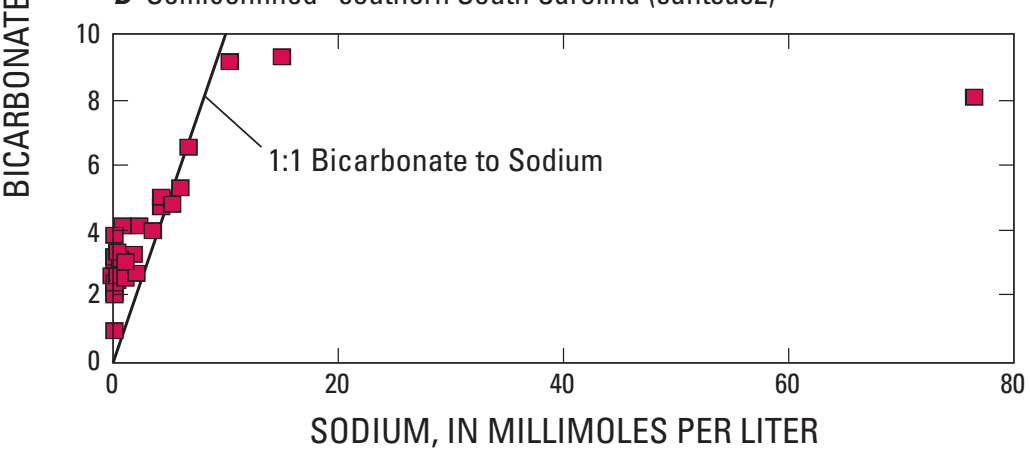

Figure 11. Molar concentrations of calcium plus magnesium compared to bicarbonate in domestic wells in the Upper Floridan aquifer for $A$, unconfined areas, $B$, semiconfined areas, $C$, confined areas, and $D$, molar concentration of bicarbonate to sodium in semiconfined areas in South Carolina. sodium $(1,763 \mathrm{mg} / \mathrm{L})$, chloride $(2,576 \mathrm{mg} / \mathrm{L})$, and sulfate $(1,855 \mathrm{mg} / \mathrm{L})$. Trace elements were not analyzed in this sample collected in 1998; however, in a sample collected from this well in 2005, concentrations of several trace elements typically present in seawater also had elevated concentrations including boron $(3.4 \mathrm{mg} / \mathrm{L})$, bromide $(9.5 \mathrm{mg} / \mathrm{L})$ and strontium $(8.0 \mathrm{mg} / \mathrm{L})$.

\section{Mineral Saturation Indices}

The computer program PHREEQC (Parkhurst and Appelo, 1999) was used to calculate the distribution and activities of dissolved species and the saturation state of groundwater with respect to the carbonate minerals calcite and dolomite. Comparison of the results for groundwater samples from the five sampling networks can be used to determine if the chemical composition of groundwater and the aquifer materials varies among networks in unconfined, semiconfined and confined areas. Assumptions for this program are that all dissolved species are at equilibrium, which allows the use of thermodynamic models to calculate the distribution of dissolved species. The saturation index (SI) is a measure of the departure from equilibrium and is expressed as:

$$
\mathrm{SI}=\log (\mathrm{IAP} / \mathrm{KT})
$$

where

$$
\begin{aligned}
& \text { IAP }=\quad \begin{array}{l}
\text { the ion activity product of the } \\
\text { components of the solid or } \\
\text { gaseous phase, and }
\end{array} \\
& \text { KT }=\quad \begin{array}{l}
\text { the solid or gaseous phase } \\
\text { solubility equilibrium product at } \\
\text { the specified temperature } \\
\text { (at the time of sampling). }
\end{array}
\end{aligned}
$$

When SI is equal to 0 , the solid or gaseous phase is in equilibrium with the groundwater. When SI is less than 0 , the solid or gaseous phase is undersaturated, which means that the phase has the thermodynamic potential to dissolve. When SI is greater than 0 , the solid or gaseous phase is supersaturated, and the phase has the potential to precipitate or volatilize.

Most SI values with respect to calcite are within the -0.2 to 0.2 range considered to be at equilibrium with respect to calcite (fig. 12A). The lowest median calcite SI was in the confined area in southeastern Georgia where nearly half of the samples in this network were undersaturated with respect to calcite. Most SI values with respect to 


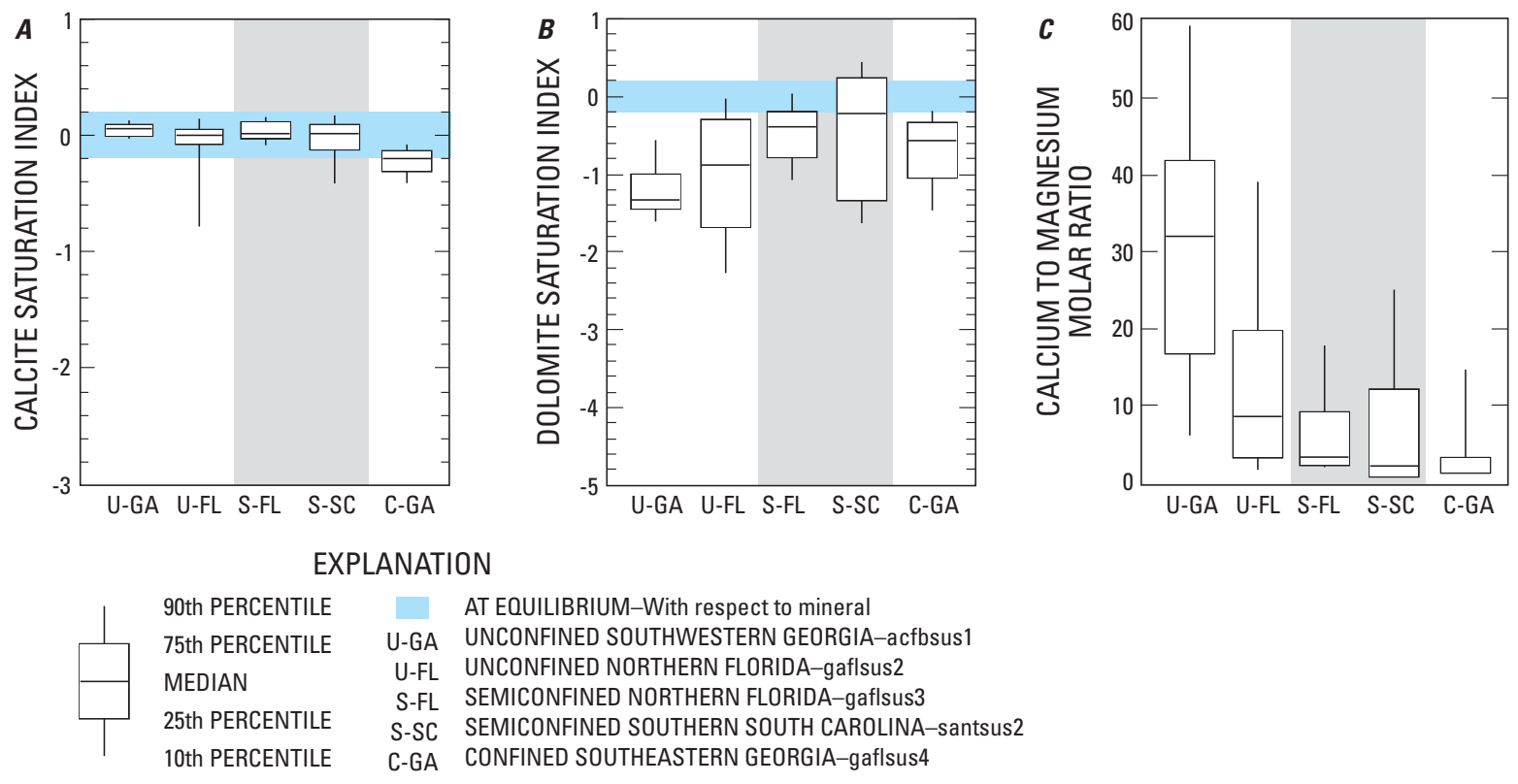

Figure 12. Boxplots showing distribution of $A$, calcite saturation index values, $B$, dolomite saturation index values, and $C$, calcium to magnesium molar ratios by sampling network.

dolomite are less than -0.2 indicating that most samples are undersaturated with respect to dolomite (fig. 12B). The highest median SI with respect to dolomite was for samples in the semiconfined area in South Carolina where nearly half the samples were at equilibrium with respect to dolomite (fig. 12B).

The ratio of calcium to magnesium concentration was computed based on molar concentrations in groundwater samples to determine the effects of dolomite in aquifer sediments on the major-ion chemistry of groundwater. The lowest values for the calcium to magnesium molar ratio in groundwater were in samples from the network in the confined area in southeastern Georgia (median ratio was 1.5) (figs. $12 C$ and 13). Median calcium to magnesium molar ratios were also low in the samples from semiconfined areas in southern South Carolina (median ratio 2.1) and in northern Florida (median ratio 3.3) (fig 12C). Molar ratios of calcium to magnesium near 1.0 probably reflect the effects of dolomite in the aquifer sediments. In contrast, the median calcium-magnesium ratio for samples from the unconfined area in southwestern Georgia was about 32, indicating that groundwater in that area had predominantly been in contact with calcite. Additionally, in this area samples were at equilibrium with respect to calcite (fig. $12 A$ ) and undersaturated with respect to dolomite (fig. 12B). The presence of dolomite in aquifer sediments in the confined area may explain why the SI values with respect to calcite for samples from this area were lower than in the samples from the other areas (fig. 12A).

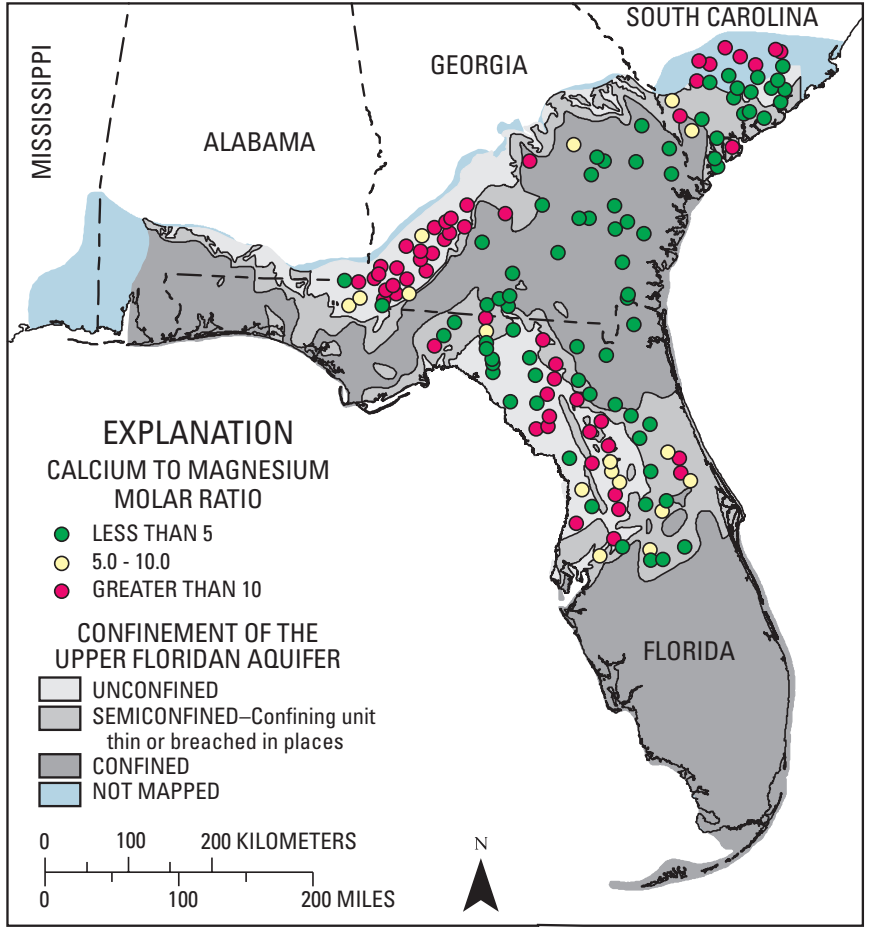

Figure 13. Spatial distribution of calcium to magnesium molar ratios in domestic wells in the Upper Floridan aquifer. 
Table 7. Descriptive statistics of concentrations of trace elements in domestic wells in the Upper Floridan aquifer.

[Concentrations are in micrograms per liter; $<$, less than. Network: santsus2, semiconfined area in South Carolina; gaflsus3, semiconfined area in northern Florida; gaflsus4, confined area in southeastern Georgia; acfbsus1, unconfined southwestern Georgia; and gaflsus2, unconfined area in northern Florida]

\begin{tabular}{|c|c|c|c|c|c|}
\hline $\begin{array}{c}\text { Trace } \\
\text { element }\end{array}$ & $\begin{array}{c}\text { Number } \\
\text { of analyses }\end{array}$ & $\begin{array}{l}\text { Minimum } \\
\text { reporting } \\
\text { limit }\end{array}$ & $\begin{array}{l}\text { Percent of } \\
\text { samples less } \\
\text { than minimum } \\
\text { reporting limit }\end{array}$ & $\begin{array}{c}\text { Maximum } \\
\text { concentration }\end{array}$ & $\begin{array}{l}\text { Network with } \\
\text { maximum } \\
\text { concentration }\end{array}$ \\
\hline Aluminum & 149 & 1.6 & 68 & 13.3 & santsus2 \\
\hline Antimony & 148 & 1.0 & 99 & 1.1 & gaflsus3 \\
\hline Arsenic & 149 & 1.0 & 88 & 9.9 & gaflsus3 \\
\hline Barium & 149 & 1.0 & 11 & 452 & gaflsus4 \\
\hline Beryllium & 148 & 1.0 & 100 & $<1.0$ & -- \\
\hline Boron & 119 & 8.0 & 22 & 69 & gaflsus3 \\
\hline Cadmium & 148 & 1.0 & 100 & $<1.0$ & -- \\
\hline Chromium & 149 & 1.0 & 59 & 9 & gaflsus4 \\
\hline Cobalt & 148 & 1.0 & 100 & $<1.0$ & -- \\
\hline Copper & 148 & 1.0 & 75 & 10.6 & acfbsus1 \\
\hline Iron & 149 & 10.0 & 58 & 3,640 & gaflsus2 \\
\hline Lead & 148 & 1.0 & 90 & 5.1 & gaflsus3 \\
\hline Lithium & 119 & 1.0 & 50 & 13.6 & santsus2 \\
\hline Manganese & 148 & 1.0 & 50 & 107 & gaflsus4 \\
\hline Molybdenum & 148 & 1.0 & 78 & 18.2 & gaflsus2 \\
\hline Nickel & 148 & 1.0 & 58 & 9.8 & gaflsus2 \\
\hline Selenium & 149 & 1.0 & 89 & 10.8 & gaflsus2 \\
\hline Silver & 133 & 1.0 & 100 & $<1.0$ & -- \\
\hline Strontium & 119 & 10.0 & 0 & 5,050 & gaflsus4 \\
\hline Thallium & 119 & 1.0 & 100 & $<1.0$ & -- \\
\hline Uranium & 148 & 1.0 & 92 & 16.0 & gaflsus3 \\
\hline Vanadium & 119 & 1.0 & 56 & 43.3 & gaflsus3 \\
\hline Zinc & 149 & 1.0 & 21 & 175 & gaflsus4 \\
\hline
\end{tabular}

\section{Trace Elements and Radon}

Trace element concentrations generally are low in samples collected from the domestic wells in the Upper Floridan aquifer, and no MCLs were exceeded (tables 7 and 8). SMCLs were exceeded for 12.8 percent of samples for iron and 4 percent of samples for manganese (table 8). For 19 of the 23 trace elements analyzed, more than 50 percent of samples had concentrations less than minimum reporting limits of $1 \mu \mathrm{g} / \mathrm{L}$, and all concentrations were less than minimum reporting limits for five trace elements (beryllium, cadmium, cobalt, silver, and thallium) (table 7). Minimum reporting limits were assigned at $1.0 \mu \mathrm{g} / \mathrm{L}$, except for aluminum $(1.6 \mu \mathrm{g} / \mathrm{L})$, boron $(8.0 \mu \mathrm{g} / \mathrm{L})$ and iron and strontium
$(10 \mu \mathrm{g} / \mathrm{L})$. Iron and manganese concentrations were generally low, with iron concentrations ranging from less than 10 to $3,640 \mu \mathrm{g} / \mathrm{L}$ and manganese concentrations range from less than 1 to $107 \mu \mathrm{g} / \mathrm{L}$ (table 7). The maximum iron concentration of $3,640 \mu \mathrm{g} / \mathrm{L}$ was found in a sample from the unconfined area in northern Florida. The maximum manganese concentration, $107 \mu \mathrm{g} / \mathrm{L}$, was measured in a sample from the confined area in southeastern Georgia. Concentrations of trace elements do not appear related to confinement category, but are probably related to spatial differences in lithology in the aquifer materials or the overlying materials.

Radon concentrations were highly variable in the Upper Floridan aquifer, ranging from below the reporting level of 10 picocuries per liter $(\mathrm{pCi} / \mathrm{L})$ to about $6,000 \mathrm{pCi} / \mathrm{L}$. 
Table 8. Comparison of concentrations of trace elements in domestic wells in the Upper Floridan aquifer to human-health benchmarks and non-health guidelines for drinking water.

[MCLs and SMCLs are U.S. Environmental Protection Agency (USEPA) Maximum Contaminant Levels (MCLs) and Secondary Maximum Contaminant Levels (SMCLs) for public-water supplies; HBSLs are health-based screening levels developed by the U.S. Geological Survey using USEPA toxicity data and methods (Toccalino and Norman, 2006); $\mu \mathrm{g} / \mathrm{L}$, microgam per liter; --, not applicable]

\begin{tabular}{|c|c|c|c|c|c|c|c|c|}
\hline \multirow[t]{3}{*}{ Trace element } & \multicolumn{4}{|c|}{ Benchmark of guideline } & \multicolumn{4}{|c|}{ Samples exceeding benchmarks or non-health guidelines } \\
\hline & \multicolumn{2}{|c|}{ Human-health benchmark } & \multicolumn{2}{|c|}{ Non-health guideline } & \multicolumn{2}{|c|}{ Human-health benchmark } & \multicolumn{2}{|c|}{ Non-health guideline } \\
\hline & Value & Type & Value & Type & Value & Percent & Value & Percent \\
\hline Aluminum & -- & -- & 50 to 200 & SMCL & -- & -- & 0 & 0.0 \\
\hline Antimony & 6 & MCL & -- & -- & 0 & 0.0 & -- & -- \\
\hline Arsenic & 10 & MCL & -- & -- & 0 & 0.0 & -- & -- \\
\hline Barium & 2,000 & MCL & -- & -- & 0 & 0.0 & -- & -- \\
\hline Beryllium & 4 & MCL & -- & -- & 0 & 0.0 & -- & -- \\
\hline Boron & 1,000 & HBSL & -- & -- & 0 & 0.0 & -- & -- \\
\hline Cadmium & 5 & MCL & -- & -- & 0 & 0.0 & -- & -- \\
\hline Chromium & 100 & MCL & -- & -- & 0 & 0.0 & -- & -- \\
\hline Cobalt & -- & -- & -- & -- & -- & -- & -- & -- \\
\hline Copper $^{1}$ & 1,300 & Action level & 1,000 & SMCL & 0 & 0.0 & 0 & 0.0 \\
\hline Iron & -- & -- & 300 & SMCL & 0 & 0.0 & 19 & 12.8 \\
\hline Lead $^{1}$ & 15 & Action level & -- & -- & 0 & 0.0 & -- & -- \\
\hline Lithium & -- & -- & -- & -- & -- & -- & -- & -- \\
\hline Manganese & 300 & HBSL & 50 & SMCL & 0 & 0.0 & 6 & 4.1 \\
\hline Molybdenum & 40 & HBSL & -- & -- & 0 & 0.0 & -- & -- \\
\hline Nickel & 100 & HBSL & -- & -- & 0 & 0.0 & -- & -- \\
\hline Selenium & 50 & MCL & -- & -- & 0 & 0.0 & -- & -- \\
\hline Silver & 100 & HBSL & 100 & SMCL & 0 & 0.0 & 0 & 0.0 \\
\hline Strontium & 4,000 & HBSL & -- & -- & 3 & 2.5 & -- & -- \\
\hline Thallium & 2 & MCL & -- & -- & 0 & 0.0 & -- & -- \\
\hline Uranium & 30 & MCL & -- & -- & 0 & 0.0 & -- & -- \\
\hline Vanadium & -- & -- & -- & -- & -- & -- & -- & -- \\
\hline Zinc & 2,000 & HBSL & 5,000 & SMCL & 0 & 0.0 & 0 & -- \\
\hline
\end{tabular}

${ }^{1}$ Lead and copper are regulated by a Treatment Technique that requires systems to control the corrosiveness of their water. If more than 10 percent of tap water samples exceed the action level, water systems must take additional steps. The action levels are $1.3 \mu \mathrm{g} / \mathrm{L}$ for copper and $0.015 \mu \mathrm{g} / \mathrm{L}$ for lead (U.S. Environmental Protection Agency, 2006).

The median radon value for all samples in the Upper Floridan aquifer was $198 \mathrm{pCi} / \mathrm{L}$. About 40 percent of radon values $(55$ of 136 samples) were greater than the USEPA proposed MCL of $300 \mathrm{pCi} / \mathrm{L}$ (U.S. Environmental Protection Agency, 1999) (fig. 14). The highest radon values were in the unconfined area in northern Florida, where 25 of 30 samples (about 83 percent) had radon concentrations greater than $300 \mathrm{pCi} / \mathrm{L}$ and 14 samples (47 percent) had radon greater than $1,000 \mathrm{pCi} / \mathrm{L}$ (fig. 14). In the four other sampling networks, 4 to 64 percent of samples had radon concentrations greater than $300 \mathrm{pCi} / \mathrm{L}$. Radon concentrations in groundwater are dependent upon the uranium and radium content of the rocks comprising the aquifer materials and the physical characteristics of the aquifer materials (Cecil and Green, 2000). The higher radon values in the unconfined area in Florida are probably not related to confinement, but are related to spatial differences in uranium content in the aquifer materials and overlying sands and clays or to differences in physical aquifer properties. In a recent study in Tampa, Florida, Katz and others (2008) reported that radon concentrations were higher in the water samples from wells installed in the overlying clay and sand of the surficial aquifer than in samples from wells in the underlying Upper Floridan aquifer. 


\section{Occurrence and Distribution of Selected Contaminants}

Samples from 148 domestic wells completed in the Upper Floridan aquifer were analyzed for a number of constituents that are considered anthropogenic contaminants: nitrate, VOCs, and pesticides. Results show that water in this aquifer is of good quality and no drinking-water standards or humanhealth guidelines were exceeded for any of the anthropogenic contaminants. This section describes the occurrence and distribution of these contaminants in groundwater as well as an assessment of the relative importance of factors affecting the concentrations of nitrate, VOCs, and pesticides in domestic wells in the Upper Floridan aquifer. Nitrate concentrations are described and compared by sampling network and by confinement and land-use categories. The occurrence and distribution of VOCs and pesticides are compared by confinement and land-use categories. For comparisons by confinement category, the samples from the unconfined area include the 58 samples from the unconfined areas in southwestern Georgia and northern Florida and the samples from semiconfined areas include the 60 samples from the semiconfined areas in northern Florida and southern South Carolina.

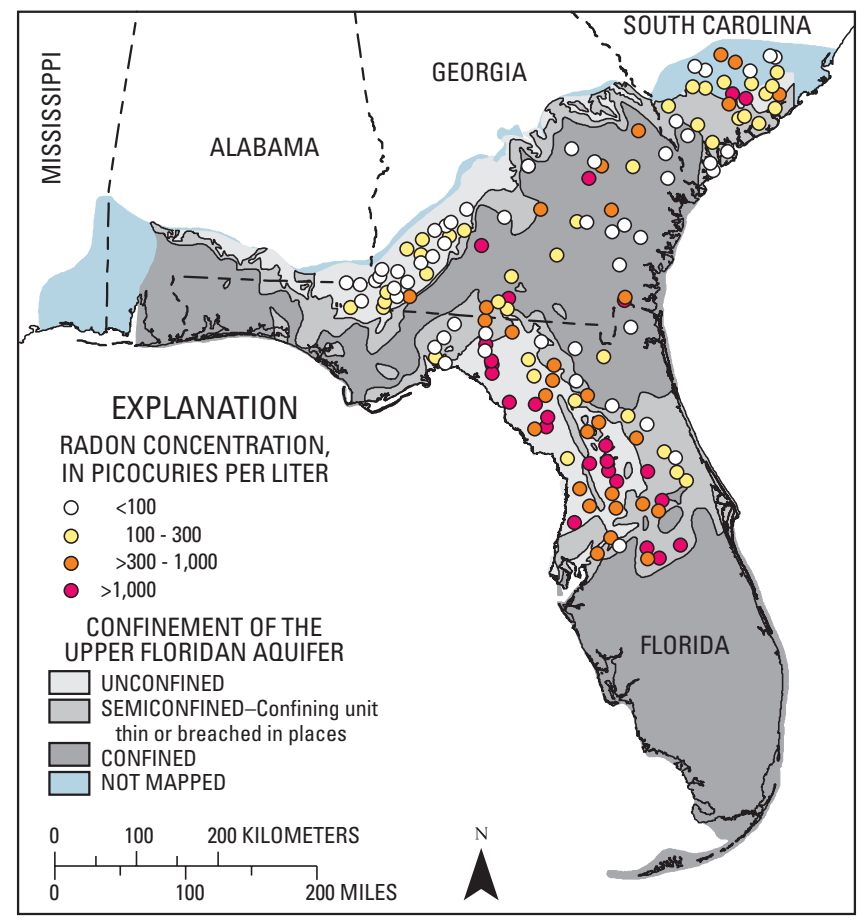

Figure 14. Spatial distribution of radon concentrations in domestic wells in the Upper Floridan aquifer.

\section{Nitrate}

Nitrogen is widely used as a fertilizer for agricultural activities and is also present in human and animal waste; therefore, the land surface is exposed to nitrogen from various sources. Nitrate is a highly soluble form of nitrogen that can readily leach into the groundwater and can also be denitrified to the form of nitrogen gas. The concentrations of nitrate in groundwater are a concern because of the potential humanhealth effects, specifically methemoglobinemia in infants, which has led the USEPA to establish the MCL for nitrate at $10 \mathrm{mg} / \mathrm{L}$ as nitrogen (U.S. Environmental Protection Agency, 2006). The widespread occurrence of nitrate, in combination with its potential for human-health effects, makes distribution of nitrate concentrations in groundwater an important issue to understand.

\section{Occurrence and Distribution of Nitrate}

Nitrate concentrations in the Upper Floridan aquifer ranged from less than the laboratory reporting level of $0.06 \mathrm{mg} / \mathrm{L}$ to $8 \mathrm{mg} / \mathrm{L}$, with a median nitrate concentration less than $0.06 \mathrm{mg} / \mathrm{L}$ (as nitrogen). Nitrate concentrations did not exceed the MCL for drinking water of $10 \mathrm{mg} / \mathrm{L}$. The median nitrate concentration for the samples in this study is similar

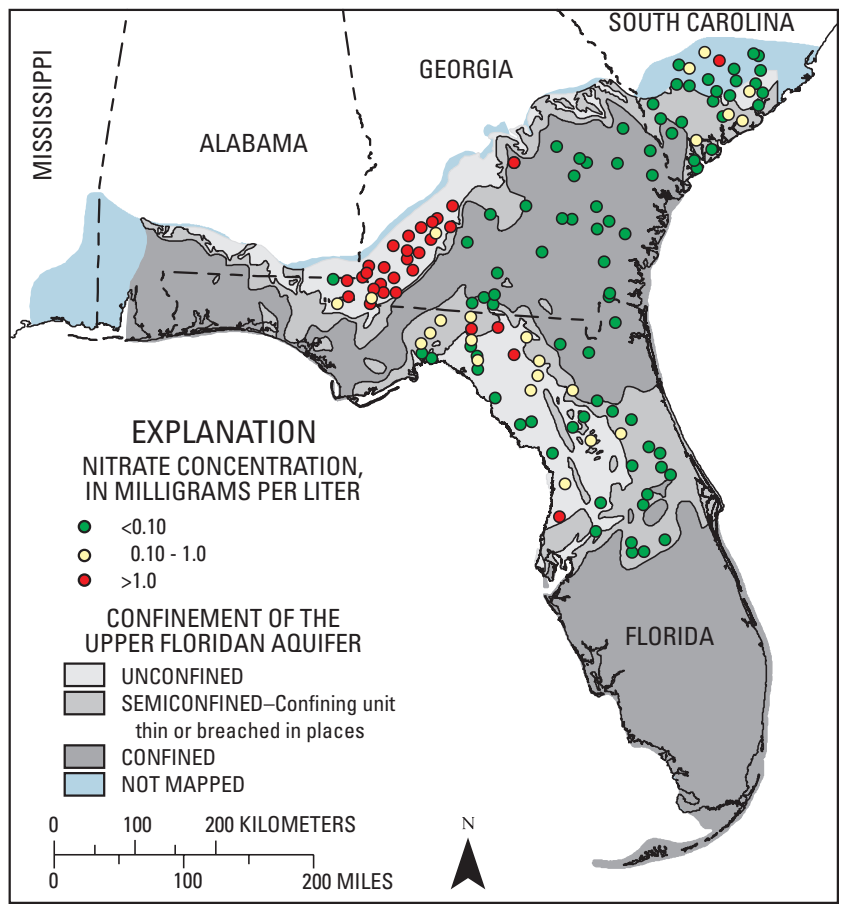

Figure 15. Spatial distribution of nitrate concentration in domestic wells in the Upper Floridan aquifer. 
Table 9. Median nitrate concentrations in domestic wells in the Upper Floridan aquifer and results of the Peto-Prentice test to determine differences in concentration among the three confinement categories.

[p-values less than alpha value of 0.05 indicate significant difference; $<$, less than]

\begin{tabular}{lcccc}
\hline & Unconfined & Semiconfined & Confined & p-value \\
\hline Number of samples & 58 & 60 & 30 & \\
Median nitrate concentration & 1.46 & $<0.06$ & $<0.06$ & $<0.001$ \\
\hline
\end{tabular}

Table 10. Results of the Peto-Prentice test to determine differences in nitrate concentration in domestic wells in the Upper Floridan aquifer between individual confinement categories using pairwise comparisons.

[p-values less than alpha value of 0.017 indicate significant difference; NS, correlation not significant at an alpha value of $0.017 ;<$, less than]

\begin{tabular}{|c|c|c|c|}
\hline & \multirow[t]{2}{*}{ Unconfined } & Semiconfined & Confined \\
\hline & & p-value & p-value \\
\hline Unconfined & & $<0.001$ & $<0.001$ \\
\hline Semiconfined & & & $0.0171(\mathrm{NS})$ \\
\hline Confined & & & \\
\hline
\end{tabular}

to the median nitrate concentration of $0.05 \mathrm{mg} / \mathrm{L}$ for samples from a previous study that included results from nearly 800 wells (monitoring, domestic, public supply, and other types of wells) in the Upper Floridan aquifer in southern Georgia and northern Florida (Berndt, 1996).

Nitrate concentrations varied spatially in the Upper Floridan aquifer. Concentrations were highest in the unconfined area in southwestern Georgia and were lowest in

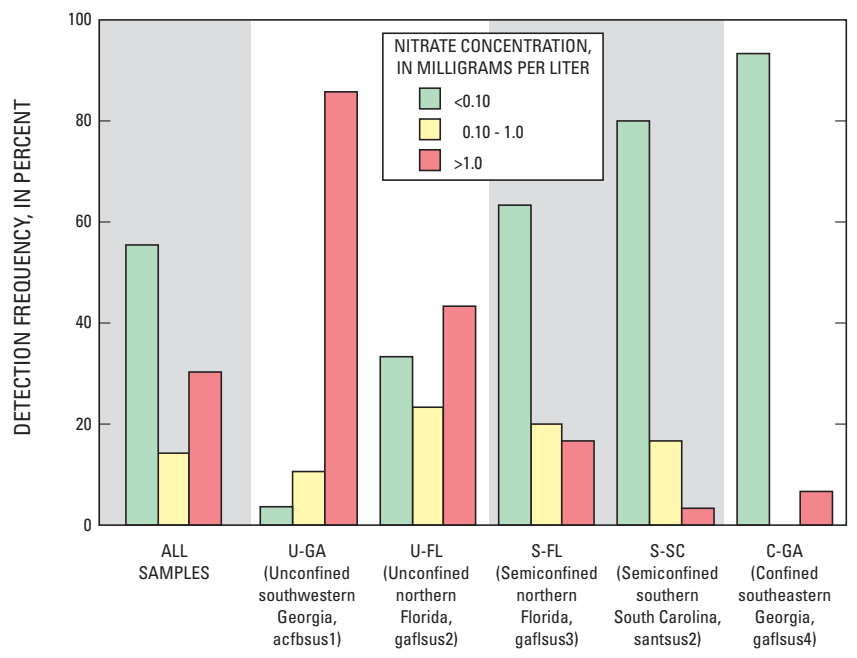

Figure 16. Percentage of nitrate concentrations at selected concentration levels in the entire data set and by sampling network. the confined area in southeastern Georgia (fig. 15). Overall, about 30 percent of samples had concentrations greater than $1 \mathrm{mg} / \mathrm{L}$, a level which is indicative of human influence in many parts of the United States (Nolan and Hitt, 2003). However, the percentage of samples with concentrations greater than $1 \mathrm{mg} / \mathrm{L}$ varied among the sampling networks, with the highest percentages in the two networks in unconfined areas (fig. 16). The percentage of samples with concentrations greater than $1 \mathrm{mg} / \mathrm{L}$ ranged from 86 and 40 percent for samples in unconfined areas in southwestern Georgia and northern Florida, respectively, to 3 percent of samples in the semiconfined area in South Carolina (figs. 15 and 16). For the semiconfined area in northern Florida, about 17 percent of samples had nitrate concentrations greater than $1 \mathrm{mg} / \mathrm{L}$. For the confined area in southeastern Georgia, 7 percent of samples had nitrate concentrations greater than $1 \mathrm{mg} / \mathrm{L}$ and nitrate was not detected in 27 samples ( 90 percent).

\section{Factors Affecting Nitrate Concentrations}

Comparison of nitrate concentrations among the three confinement categories shows that nitrate concentrations are significantly different (p-value less than 0.001) among the three categories (table 9), and that median nitrate concentrations are significantly higher in samples from the unconfined category compared to the semiconfined and confined categories (p-values less than 0.001) (table 10). The median nitrate concentration is $1.46 \mathrm{mg} / \mathrm{L}$ for 58 samples from the unconfined category, compared to median concentrations less 
than $0.06 \mathrm{mg} / \mathrm{L}$ in the semiconfined and confined categories (fig. 17A; table 9). The median dissolved oxygen concentration is also higher in the unconfined category (fig. 17B). The higher nitrate concentrations in the unconfined category indicates the greater susceptibility of unconfined areas of aquifers to contamination from land-surface activities, especially in carbonate aquifers where the thickness and type of sediments that overlie the aquifer (or the lack thereof) affect the development of secondary porosity, permeability, recharge rate, and groundwater residence time (Brahana and others, 1988).

Comparison of nitrate concentrations among the five sampling networks shows that nitrate concentrations are significantly different (p-value less than 0.001) (table 11), and that the median nitrate concentration is highest $(2.43 \mathrm{mg} / \mathrm{L})$ for samples from the unconfined area in southwestern Georgia. Median nitrate concentrations in the other sampling networks are $0.54 \mathrm{mg} / \mathrm{L}$ in the unconfined area in northern Florida and less than $0.1 \mathrm{mg} / \mathrm{L}$ for each of the remaining three sampling networks in semiconfined and confined areas (fig. 18A; table 11). The median dissolved oxygen is also highest in the unconfined area in southwestern Georgia (fig. 18B). Comparison of nitrate concentrations between the two networks in unconfined areas showed that nitrate concentrations are significantly different (table 12), implying that factors in addition to confinement are affecting nitrate concentrations in these two unconfined areas. One potential factor is fertilizer sources of nitrogen - the median amount of nitrogen applied as fertilizer was about twice as high in the network in the unconfined area in southwestern Georgia than in the unconfined area in northern Florida (fig. 18D; table 3). For the two networks in semiconfined areas, nitrate concentrations are not significantly different from one another (table 12).

Because of the significant difference in nitrate concentrations between the two unconfined networks, examination of factors in addition to confinement, such as well depth, soil hydrologic properties, and sources of nitrogen can provide information
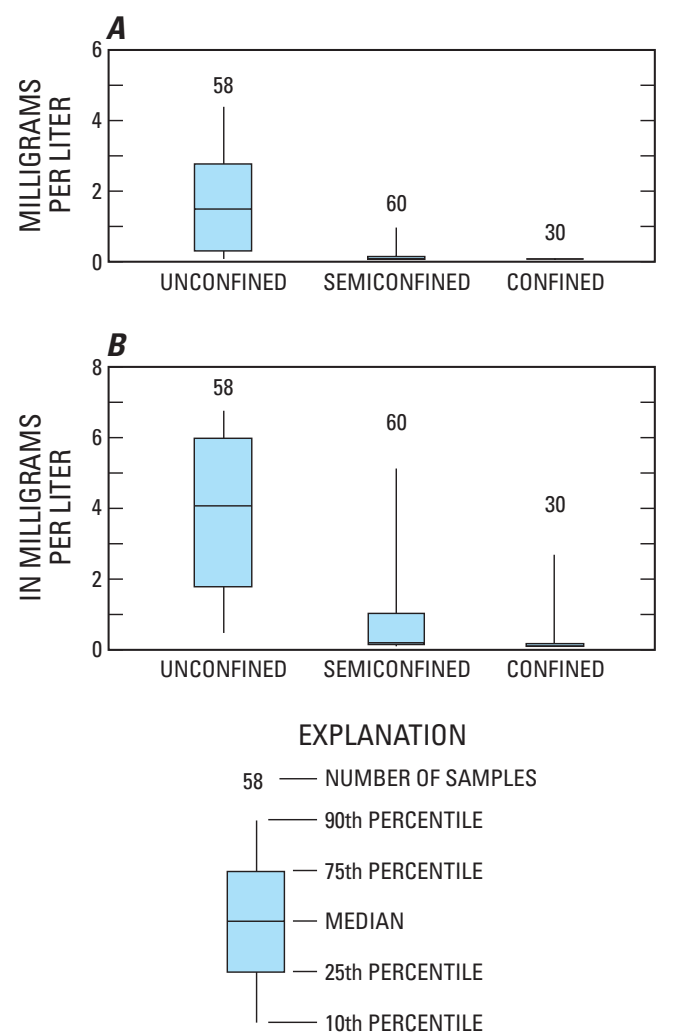

Figure 17. Concentrations of $A$, nitrate and $B$, dissolved oxygen concentrations in domestic wells in the Upper Floridan aquifer by confinement category.
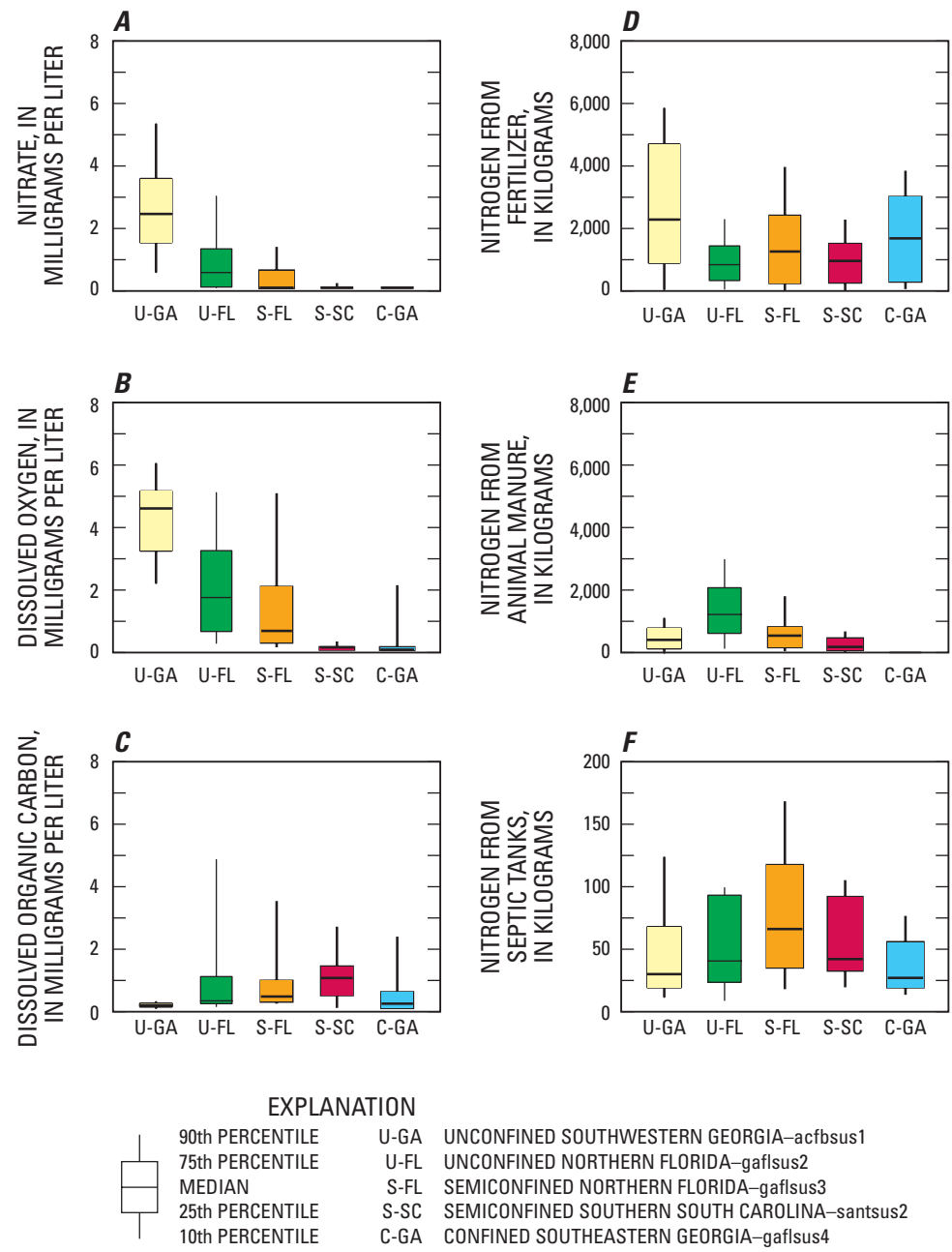

Figure 18. Distribution by sampling network of $A$, nitrate, $B$, dissolved oxygen, and $C$, dissolved organic carbon concentrations; and estimated nitrogen contributions in the 500-m-radius area surrounding each well from $D$, fertilizer, $E$, animal manure, and $F$, septic tanks. 
about the relative significance of factors affecting nitrate concentration in groundwater.

Correlations of nitrate concentrations in groundwater with selected explanatory variables potentially related to sources of nitrate and the transport of nitrate to groundwater show that numerous factors were significantly correlated with nitrate concentration when all of the 148 samples were included (12 factors), but fewer were significant for individual sampling networks (3 or less factors for each) (table 13). As reported earlier, because nitrate concentrations were less than reporting levels in 90 percent of the 30 samples in the network in the confined area, correlation analyses were not performed for that sampling network. Correlation analyses were performed for the factors given in table 3 along with well depth, dissolved oxygen concentration, and organic carbon concentration, but only those with a significant correlation in one of the categories or networks are given in table 13. The large number of factors with significant correlations for the entire data set and the few significant correlations within sampling networks probably indicates that variations in nitrate concentration and some explanatory factors were greater between the networks than within individual networks. As previously discussed, nitrate concentrations were significantly different between some sampling networks. Additionally, several of the explanatory factors showed a large range in values within sampling networks (table 3 ).

For the entire data set of 148 samples, several factors related to land use and sources of nitrogen in the areas surrounding wells were significantly correlated with nitrate concentrations. Nitrate concentrations were significantly correlated with the percentage of agricultural land use (correlation coefficient, tau $=0.196)$, nitrogen from fertilizer $($ tau $=0.177)$, and nitrogen from animal manure $(\mathrm{tau}=0.261)$ (table 14). The significant correlations between nitrate concentration and the percentage of agricultural land use and the agricultural sources of nitrogen (fertilizer and animal manure) indicate that higher nitrate concentrations are associated with increasing agricultural activities. In samples from the unconfined category, significant correlations are also seen between nitrate concentrations and the percentage of agricultural land use and agricultural fertilizer sources of nitrogen. These two factors are not significantly correlated with nitrate concentrations in the samples from the semiconfined category (table 13), implying that nitrate concentrations are more related to agricultural sources in unconfined areas than in semiconfined areas. Additional factors that are significantly correlated with nitrate concentration in the unconfined category include the soil properties of percentage clay, silt, and sand (inverse correlation). These significant

Table 11. Median nitrate concentration in domestic wells in the Upper Floridan aquifer and results of the Peto-Prentice test to determine differences in concentration among the five sampling networks.

[p-value less than alpha value of 0.05 indicate significant difference; $<$, less than]

\begin{tabular}{ccccccc}
\hline & Unconfined & Unconfined & Semiconfined & Semiconfined & Confined & p-value \\
\cline { 2 - 5 } & acfbsus1 & gaflsus2 & gaflsus3 & santsus2 & gaflsus4 & \\
\hline $\begin{array}{c}\text { Number of } \\
\text { samples }\end{array}$ & 28 & 30 & 30 & 30 & 30 & $<0.001$ \\
$\begin{array}{c}\text { Median nitrate } \\
\text { concentration }\end{array}$ & 2.43 & 0.54 & 0.08 & $<0.06$ & $<0.06$ & \\
\hline
\end{tabular}

Table 12. Results of the Peto-Prentice test to determine differences in nitrate concentration in domestic wells in the Upper Floridan aquifer between individual sampling networks using pairwise comparisons.

[p-value less than alpha value of 0.010 indicate significant difference; NS, Correlation not significant at an alpha value of $0.010 ;<$, less than]

\begin{tabular}{lccccc}
\hline & Unconfined & Unconfined & Semiconfined & Semiconfined & Confined \\
\cline { 2 - 6 } & acfbsus1 & gaflsus2 & gaflsus3 & santsus2 & gaflsus4 \\
\hline Unconfined acfbsus1 & & $<0.001$ & $<0.001$ & $<0.001$ & $<0.001$ \\
Unconfined gaflsus2 & & $0.0263(\mathrm{NS})$ & $<0.001$ & $<0.001$ \\
Semiconfined gaflsus3 & & & 0.149 (NS) & 0.005 \\
Semiconfined santsus2 & & & & 0.115 (NS) \\
Confined gaflsus4 & & & & \\
\hline
\end{tabular}




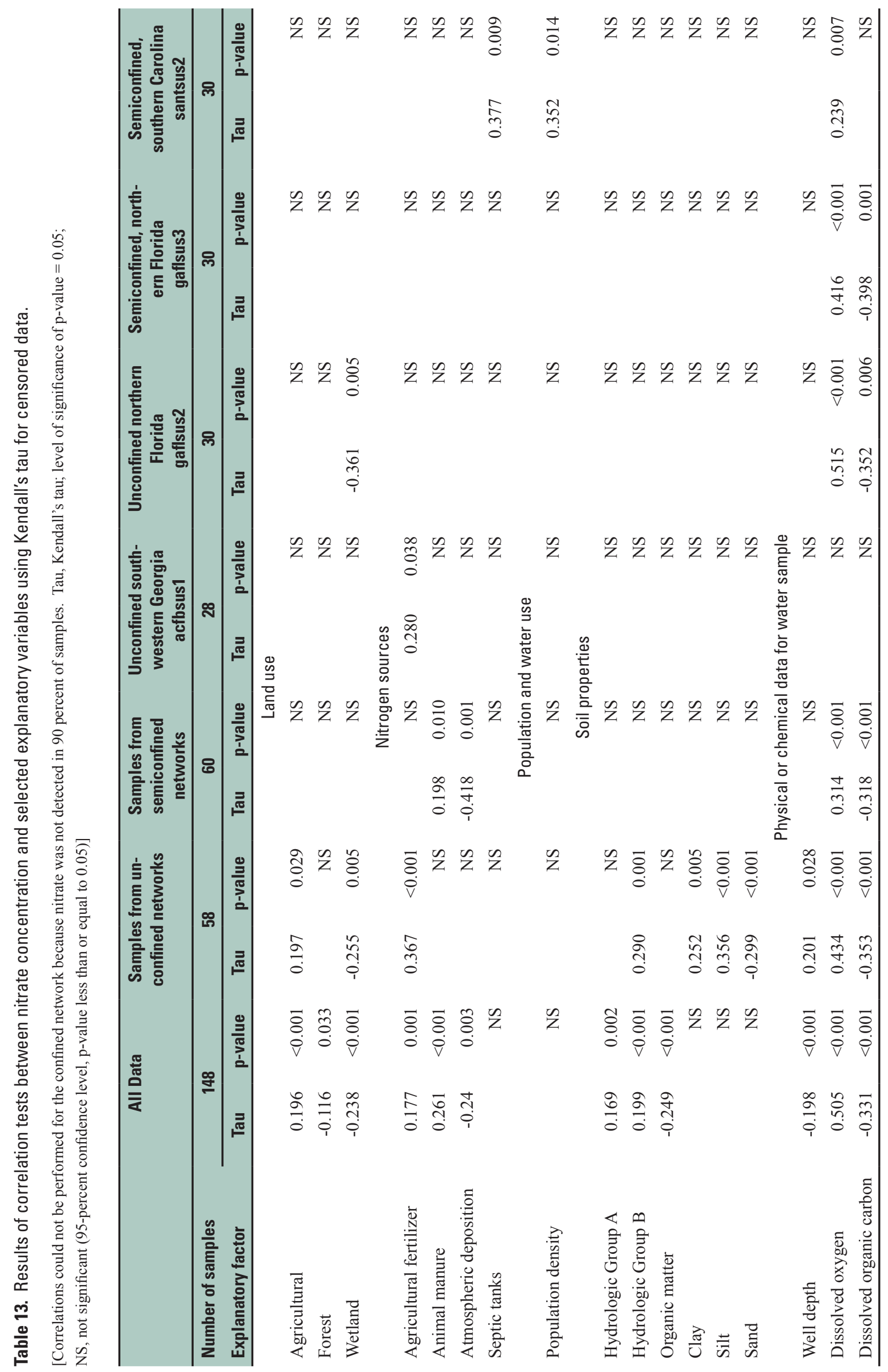


correlations were not observed for any of the other sample groups (table 13), which may indicate the importance of soil properties in unconfined areas of aquifers.

For the entire data set, significant inverse correlations are noted between nitrate concentrations and the percentage of land in forest and wetland categories as well as nitrogen from atmospheric deposition, thus indicating that increasing amounts of these factors are associated with lower nitrate concentrations. This correlation might be expected between nitrate concentration and percentage of land in forest and wetland because these two land-use settings are not expected to be sources of nitrogen, but the inverse correlation between nitrate concentration and nitrogen from atmospheric deposition is problematic. Inverse correlations of nitrate with nitrogen from atmospheric deposition were also seen for the 60 samples from the semiconfined category. These correlations could be related to the very low nitrate concentrations in the groundwater samples in the semiconfined area in southern South Carolina (median nitrate concentration was less than $0.06 \mathrm{mg} / \mathrm{L}$ ) such that very small differences in nitrate concentration (less than $0.1 \mathrm{mg} / \mathrm{L}$ ) could be related to increasing amounts of atmospheric deposition of nitrogen (tables 3 and 13).

For the entire data set, and in all but one network, nitrate and dissolved oxygen concentrations are significantly correlated. The network in the unconfined area in southwestern Georgia was the only network where the correlation between dissolved oxygen and nitrate concentrations was not significant. The relation between dissolved oxygen and nitrate concentrations for the entire data set may be related to the denitrification of nitrate in locations where groundwater is anoxic (dissolved oxygen concentration less than $0.5 \mathrm{mg} / \mathrm{L}$; McMahon and Chapelle, 2008). Nitrate and dissolved-oxygen concentrations were not significantly correlated in the unconfined area in southwestern Georgia because the groundwater is oxic (dissolved oxygen concentration greater than or equal to $0.5 \mathrm{mg} / \mathrm{L}$ ). Under oxic conditions, nitrate would not be reduced, and nitrate concentrations would likely be affected by proximity to recharge containing sources of nitrogen.

For the entire data set, nitrate concentrations were inversely correlated with well depth, dissolved organic carbon concentrations, and percent of soil organic matter. In contrast to the inverse correlation for the entire data set, for the 58 samples in the unconfined category, nitrate concentration was positively correlated to well depth. Nitrate concentrations were not correlated with well depth in the semiconfined category or in the four sampling networks (table 13). Well depth is often used as an indication of relative residence time for groundwater, with shorter residence times expected in shallow wells compared to deeper wells. Deeper wells imply a greater depth to the water table. Increases in nitrate concentration with increasing well depth would not be expected if higher nitrate concentrations are associated with shorter residence times (or more recent recharge) or to shallow depths to water. Nitrate concentrations were inversely correlated with dissolved organic carbon concentration in the samples from the unconfined and semiconfined categories, and in the networks in the unconfined area in northern Florida and the semiconfined area in northern Florida. Organic carbon is necessary for the microbial processes that cause denitrification, so waters with elevated dissolved organic carbon concentrations would be less likely to have elevated nitrate concentrations.

\section{Volatile Organic Compounds}

The results of VOC analyses are analyzed with respect to the occurrence and distribution of VOCs, water-quality benchmarks for human health, and factors affecting VOC detections. Appendix 1 lists all the VOCs analyzed for this study, and the minimum reporting level for each VOC analyzed.

\section{Occurrence and Distribution}

Volatile organic compounds were detected in 93 of 148 samples (about 63 percent) collected from domestic wells in the Upper Floridan aquifer. These compounds are associated with many products, including plastics, adhesives, paints, gasoline, fumigants, refrigerants, and dry-cleaning fluids. Fifty-eight samples (about 39 percent) contained 1 VOC detection per sample, 24 samples (about 16 percent) contained 2 VOC detections, 6 samples (about 4 percent) contained 3 VOC detections, 3 samples ( 2 percent) contained 4 VOC detections, and 2 samples contained 5 VOC detections (fig. 19). The percentage of samples with one or more VOC detections in each sampling network ranged from 53 percent for the network in the semiconfined area in northern Florida to 70 percent for the network in confined areas

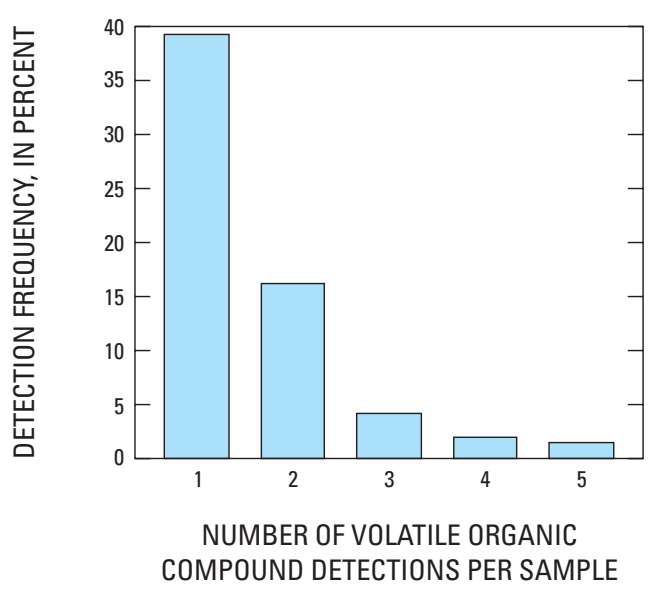

Figure 19. Detection frequencies for samples with one to five volatile organic compound detections per sample. 
in southeastern Georgia (fig. 20). The percentage of samples in the Upper Floridan aquifer containing one or more VOCs was slightly higher than the findings from national studies in which 51 percent of the wells sampled contained one or more VOCs at an assessment level of $0.02 \mu \mathrm{g} / \mathrm{L}$ (Zogorski and others, 2006, p. 16). The finding that one or more VOCs were detected in nearly two-thirds of the samples demonstrates the vulnerability of this aquifer to low-level VOC contamination.

The most frequently detected VOCs were chloroform (29 percent of samples), carbon disulfide (27 percent), and 1,2-dichloropropane (11 percent) (fig. 21). Tetrahydrofuran, acetone, tetrachloroethene (PCE), and dichlorodifluoromethane (CFC-12) were detected in 2 to 4 percent of samples and the remaining VOCs were detected in less than 2 percent of samples (fig. 21).

Chloroform is a trihalomethane compound and is a byproduct of the chlorination process. The source of chloroform in groundwater is attributed, in part, to the recycling of chlorinated waters to aquifers (Zogorski and others, 2006). Other potential sources of chloroform and other trihalomethanes to domestic wells are laundry wastewater containing bleach and the well disinfection practice of shock chlorination. Chloroform was also the most frequently detected VOC in groundwater nationwide (Zogorski and others, 2006). Carbon disulfide is a solvent used in a number of industrial applications (U.S. Environmental Protection Agency, 1994a), but it can also occur natrually due to the action of microorganisms in marine sediments and sediments in marshes (U.S. Environmental Protection Agency, 1994b). Chloroform and carbon disulfide were both frequently detected in monitoring and public supply wells from recent studies in the Tampa Bay area (Metz and others, 2006; Katz and others, 2008). Frequent detections

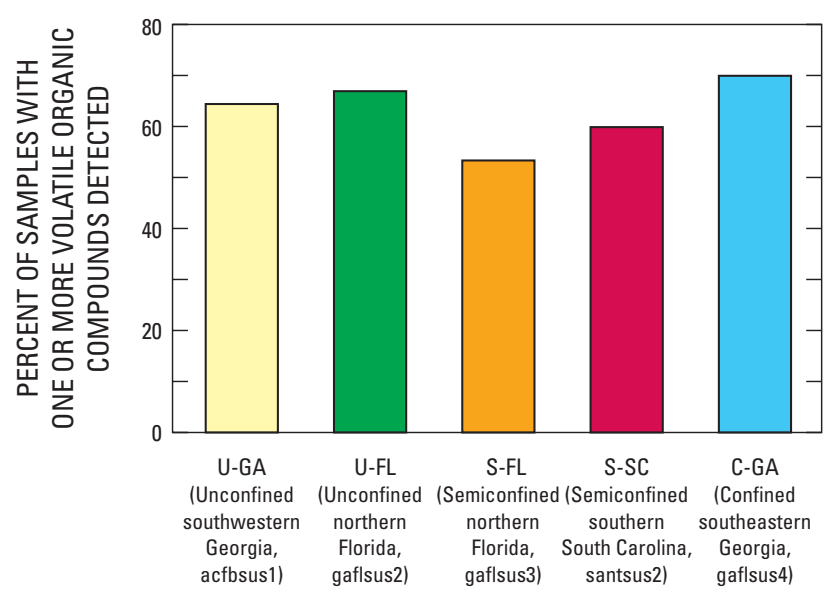

Figure 20. Detection frequencies for samples with volatile organic compound detections in each sampling network.
(59 percent) of 1,2-dichloropropane, a fumigant, were noted by Tesoriero and others (2001) in samples collected from an unconfined shallow aquifer in Washington State.

Concentrations of VOCs typically were low with 94 percent of the detections at concentrations less than $1.0 \mu \mathrm{g} / \mathrm{L}$ (fig. 22). Concentrations of the three most frequently detected VOCs - chloroform, carbon disulfide and 1,2dichloropropane-ranged from 0.01 to $1.14 \mu \mathrm{g} / \mathrm{L}$. The highest concentration of any VOC was $1,430 \mu \mathrm{g} / \mathrm{L}$ for tetrahydrofuran in a sample from the semiconfined area in South Carolina (fig. 22). Tetrahydrofuran is a solvent that is used in the preparation of adhesives, lacquers, printing inks, fat oils, and unvulcanized rubber (U.S. Department of Labor, 2008), and its occurrence at such a high concentration in this sample may be related to usage of this compound near the well. There are no human-health guidelines established for tetrahydrofuran.

\section{Comparison to Water-Quality Benchmarks for Human Health}

Comparison of concentrations of VOCs to human-health benchmarks (MCLs and HBSLs) was made to determine the potential adverse health effects of these compounds. Chloroform concentrations were compared to the MCL for

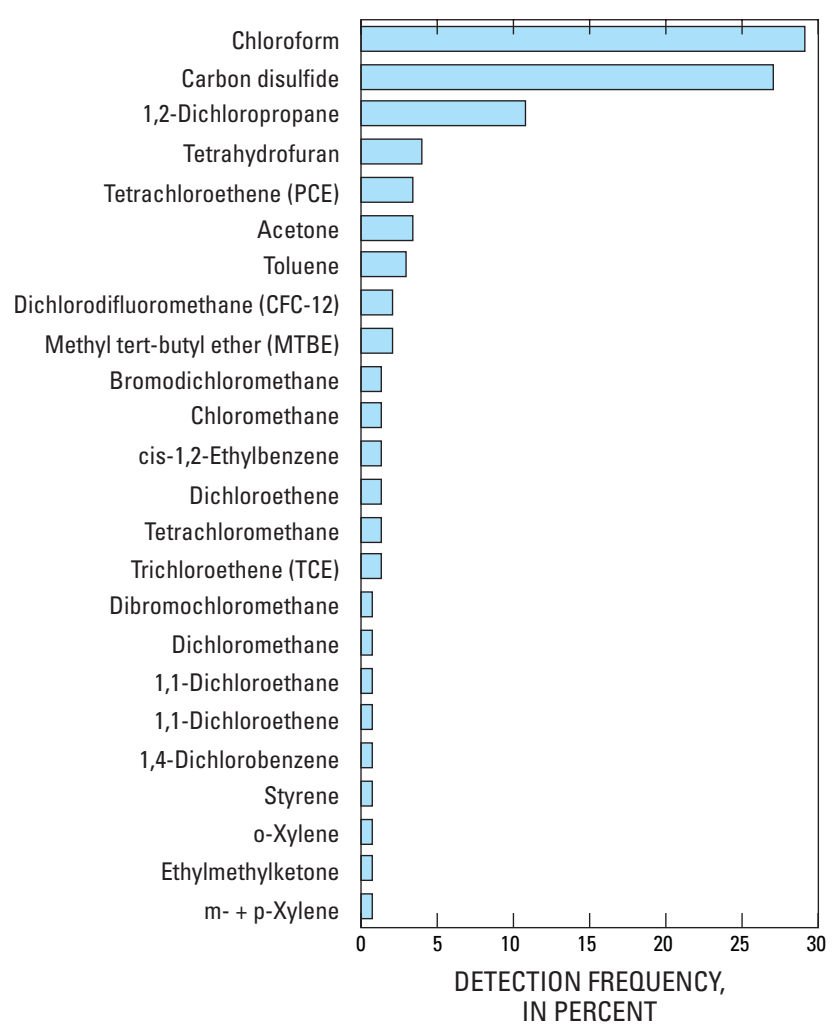

Figure 21. Detection frequencies for volatile organic compounds detected in more than 3 percent of samples. 
total trihalomethanes of $80 \mu \mathrm{g} / \mathrm{L}$ (U.S. Environmental

Protection Agency, 2006) and no concentrations exceeded this level. The maximum concentration of carbon disulfide was $1.14 \mu \mathrm{g} / \mathrm{L}$, which was not within an order of magnitude of the HBSL of $700 \mu \mathrm{g} / \mathrm{L}$ (Toccalino and others, 2007). No MCLs or HBSLs were exceeded for any of the compounds, although several compounds had benchmark quotient values greater than 0.1 (concentrations within an order of magnitude of the
MCL or HBSL) (fig. 22), including chloroform and 1,2-dichloropropane. These concentrations within an order of magnitude of MCLs or HBSLs may be considered to be "of potential human-health concern" in drinking water. Information about detection of VOCs at these concentrations could be valuable with respect to future monitoring plans and groundwater protection policies (Zogorski and others, 2006).
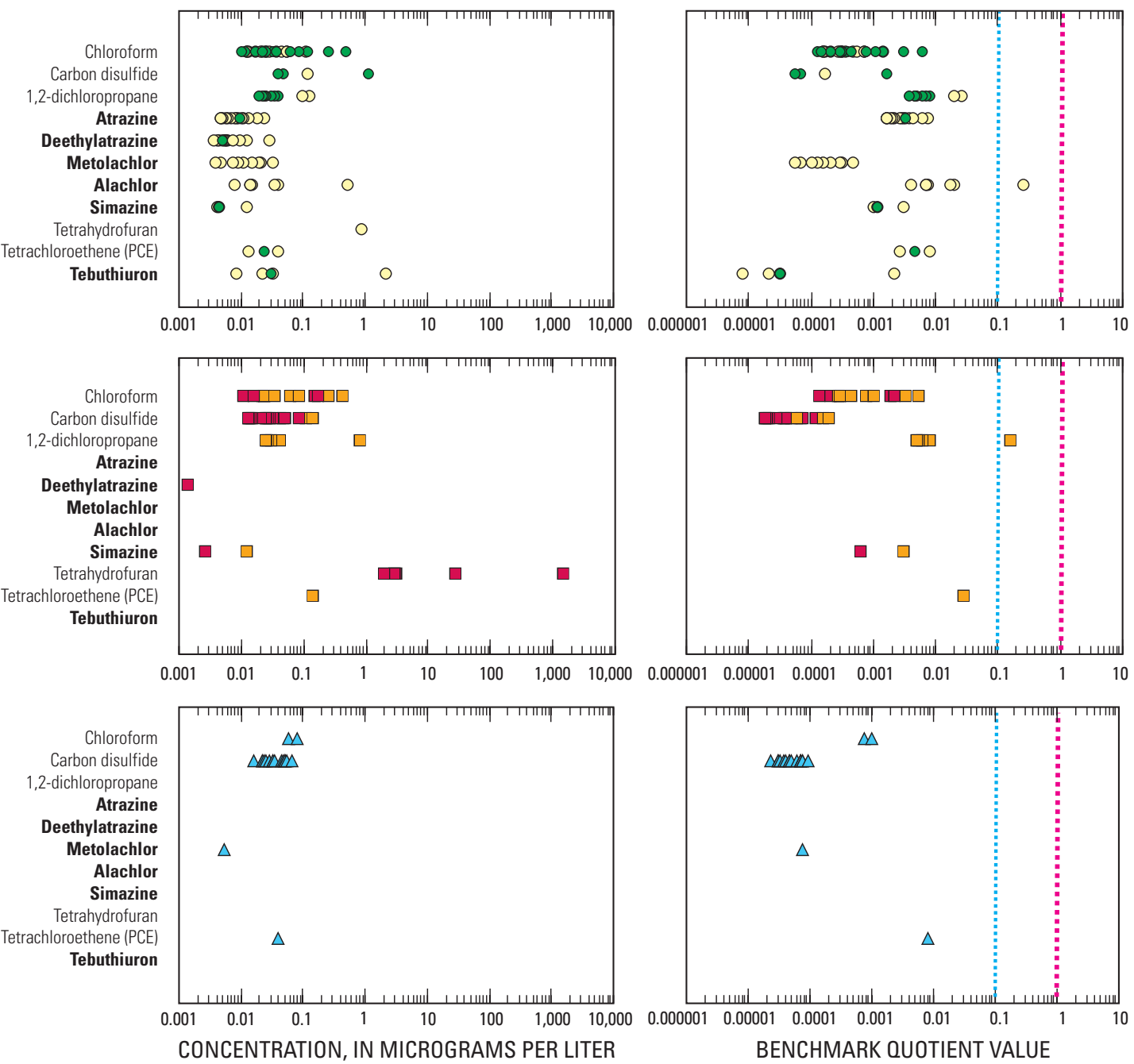

EXPLANATION

○ UNCONFINED SOUTHWESTERN GEORGIA-acfbsus1

- UNCONFINED NORTHERN FLORIDA-gaflsus2

$\square$ SEMICONFINED NORTHERN FLORIDA-gaflsus3

- SEMICONFINED SOUTHERN SOUTH CAROLINA-santsus2

$\triangle$ CONFINED SOUTHEASTERN GEORGIA-gaflsus4

COMPOUND NAMES IN BOLD ARE PESTICIDES

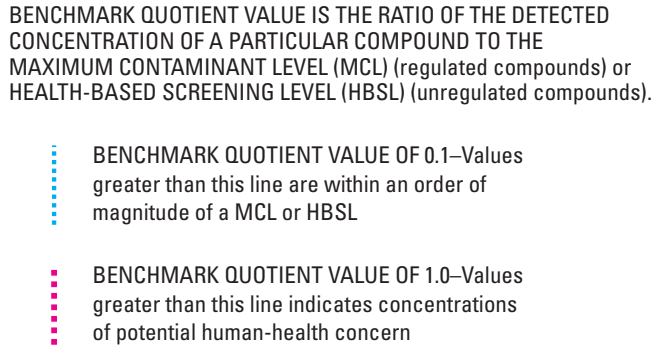

BENCHMARK QUOTIENT VALUE IS THE RATIO OF THE DETECTED CONCENTRATION OF A PARTICULAR COMPOUND TO THE MAXIMUM CONTAMINANT LEVEL (MCL) (regulated compounds) or BENCHMARK QUOTIENT VALUE OF 0.1-Values greater than this line are within an order of OF 1.0-Values of potential human-health concern

Figure 22. Concentrations and benchmark quotient values for volatile organic compounds and pesticides detected in 3 percent or more of samples. 


\section{Factors Affecting Volatile Organic Compound Detections}

The frequency of VOC detections by confinement category differed among VOCs. Chloroform was detected most frequently in samples from the unconfined category and was detected in nearly 50 percent of samples from this category (fig. 23A). In contrast, carbon disulfide was detected most frequently in the confined category and was detected in more than 60 percent of samples from this category (fig. 23A). Chloroform is associated with the presence of dissolved oxygen in groundwater, and dissolved oxygen concentrations were mostly greater than $0.5 \mathrm{mg} / \mathrm{L}$ in unconfined areas (fig. 17B). Carbon disulfide has been more frequently detected in the anoxic groundwater of the Upper Floridan aquifer (concentrations of dissolved oxygen less than $0.5 \mathrm{mg} / \mathrm{L}$ ) in an urban area in Tampa, Florida, than in oxic waters of overlying aquifers (Katz and others, 2008). The detections of 1,2-dichloropropane only in samples from the unconfined and semiconfined categories is similar to results from Tesoriero and others (2001) where 1,2-dichloropropane was detected in 59 percent of samples collected from an unconfined aquifer. In this study, groundwater in the Upper Floridan aquifer from oxic zones (dissolved oxygen greater
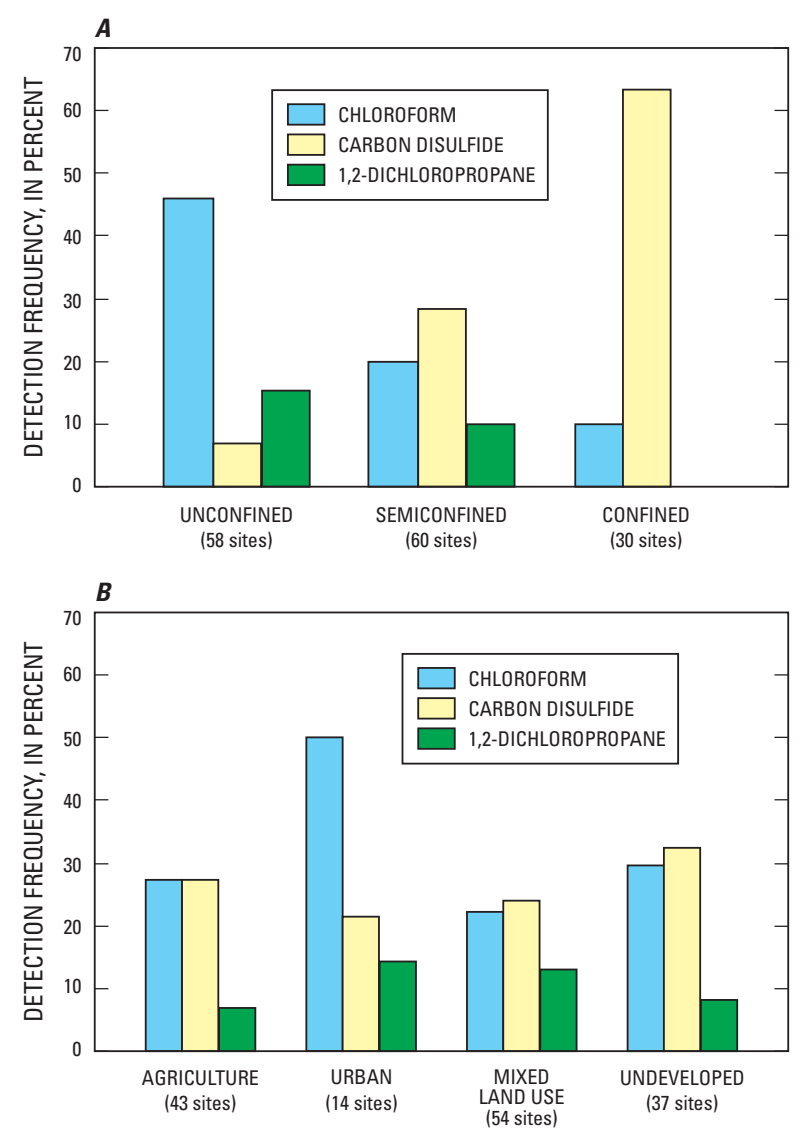

Figure 23. Detection frequencies for chloroform, carbon disulfide, and 1,2-dichloropropane by $A$, confinement category and $B$, land-use category. than $0.5 \mathrm{mg} / \mathrm{L}$ ) had a substantially higher detection frequency of 1,2-dichloropropane than samples from low-oxygen zones. The most frequently detected VOCs (chloroform, carbon disulfide, and 1,2-dichloropropane) were detected in 20 percent or more of samples in two or more land-use categories (fig. $23 \mathrm{~B}$ ), indicating the widespread production or usage of these compounds in several land-use settings. Although carbon disulfide is a solvent, it also can occur naturally, which may explain its occurrence in samples from confined areas of the Upper Floridan aquifer.

Statistical comparisons were made to assess the effect of selected factors on the occurrence of chloroform and carbon disulfide in the Upper Floridan aquifer. The Wilcoxon rank-sum test was used to compare the medians for selected chemical factors (dissolved oxygen, nitrate and dissolved organic carbon) and anthropogenic factors (land-use and population density) between samples that contained detections of chloroform and carbon disulfide and samples without detections of either compound. For chloroform, results of the Wilcoxon rank-sum test indicated that population density and urban land use for the 500-m-radius area surrounding the well site, as well as dissolved oxygen, dissolved organic carbon and nitrate concentrations in groundwater from samples with chloroform detections (43 samples) were significantly different from samples without chloroform detections (105 samples). High median values were noted in the samples with chloroform detections for population density, percent urban land use, and concentrations of dissolved oxygen and nitrate (table 14). The median concentration of dissolved organic carbon was slightly higher in samples without chloroform detected $(0.44 \mathrm{mg} / \mathrm{L})$ than in samples with chloroform detections $(0.33 \mathrm{mg} / \mathrm{L})$. Chloroform was detected more frequently in samples from the unconfined category (46 percent of samples) than in the semiconfined (20 percent of samples) or confined categories (10 percent of samples) (fig.23A). These results suggest that groundwater in oxic unconfined aquifers within densely populated urban areas could be more susceptible to chloroform occurrence than groundwater in other areas.

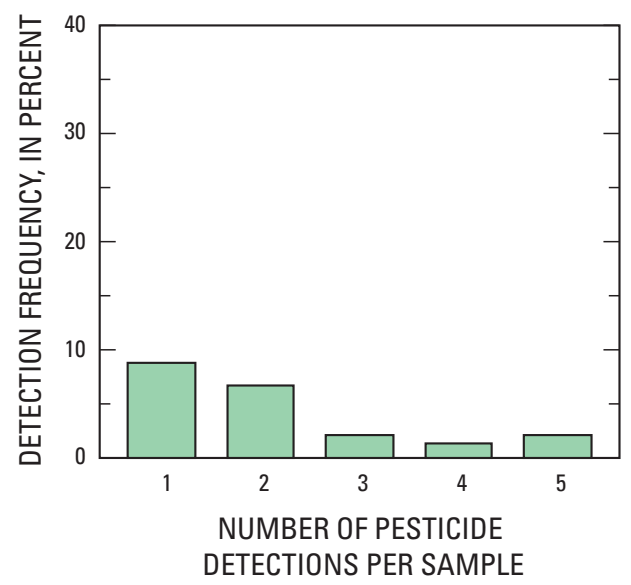

Figure 24. Detection frequencies for samples with one to five pesticide detections per sample. 
For carbon disulfide, results of the Wilcoxon rank-sum test indicated that population density in the 500-m-radius area surrounding the well, and dissolved oxygen and dissolved organic carbon concentrations in groundwater, were significantly different between the samples with carbon disulfide detections (40 samples) and those without carbon disulfide detections (108 samples) (table 15). In contrast to chloroform, the population density in the 500-m-radius area and dissolved oxygen concentrations in groundwater were lower for samples with carbon disulfide detections than for those samples without carbon disulfide detections. The median dissolved oxygen concentration for samples with carbon disulfide detections was $0.1 \mathrm{mg} / \mathrm{L}$, indicating waters are mostly anoxic (oxygen less than $0.5 \mathrm{mg} / \mathrm{L}$ ). The median dissolved organic carbon concentration was higher $(1.05 \mathrm{mg} / \mathrm{L})$ in samples with carbon disulfide detections compared to samples without detections $(0.33 \mathrm{mg} / \mathrm{L})$. Additionally, carbon disulfide was detected less frequently in samples from the unconfined category ( 7 percent of samples) than in samples from semiconfined category ( 28 percent of samples) or confined areas (63 percent of samples) (fig.23A). These results suggest that groundwater in anoxic confined aquifers with elevated dissolved organic carbon could be more susceptible to carbon disulfide occurrence than groundwater in other areas.

\section{Pesticides}

The results of pesticide analyses are evaluated with respect to the occurrence and distribution of pesticides, waterquality benchmarks for human health, and factors affecting pesticide detections. Appendix 2 lists all the pesticides and the minimum reporting level for each pesticide analyzed for this study.

\section{Occurrence and Distribution}

Pesticides were detected in 31 of the 148 samples (about 21 percent). Thirteen samples (about 9 percent of samples) contained 1 pesticide detection per sample, 10 samples (about 7 percent) contained 2 pesticide detections, 3 samples (about 2 percent) contained 3 pesticide detections, 2 samples (about 1 percent) contained 4 pesticide detections, and 3 samples (about 2 percent) contained 5 pesticide detections (fig. 24). For

Table 14. Results of the Wilcoxon rank-sum test comparing median values for selected chemical and anthropogenic factors between samples with chloroform detections and samples without chloroform detections.

$[\mathrm{mg} / \mathrm{L}$, milligrams per liter; p-values less than the alpha value of 0.05 indicate significant difference and are shown in bold; NS, difference not significant at an alpha value of 0.05 ]

\begin{tabular}{|c|c|c|c|}
\hline & Chloroform detected & Chloroform not detected & \\
\hline & $\begin{array}{l}43 \text { samples } \\
29.1 \text { percent of samples }\end{array}$ & $\begin{array}{l}105 \text { samples } \\
70.9 \text { percent of samples }\end{array}$ & \\
\hline 1990 population density, people per square kilometer & 18.81 & 11.64 & $0.1360(\mathrm{NS})$ \\
\hline Urban land use, percent & 3.54 & 0.34 & 0.0295 \\
\hline Dissolved organic carbon, $\mathrm{mg} / \mathrm{L}$ & 0.33 & 0.44 & $0.0593(\mathrm{NS})$ \\
\hline Nitrate, mg/L & 1.08 & $<0.06$ & $<.0001$ \\
\hline
\end{tabular}

Table 15. Results of the Wilcoxon rank-sum test comparing median values for selected chemical and anthropogenic factors between samples with carbon disulfide detections and samples without carbon disulfide detections.

$[\mathrm{mg} / \mathrm{L}$, milligrams per liter; $\mathrm{p}$-values less than the alpha value of 0.05 indicate significant difference and are shown in bold; NS, correlation not significant at an alpha value of 0.05 ]

\begin{tabular}{lccc}
\hline & Carbon disulfide detected & $\begin{array}{l}\text { Carbon disulfide not } \\
\text { detected }\end{array}$ \\
\hline & $\begin{array}{l}40 \text { samples } \\
27.0 \text { percent of samples }\end{array}$ & $\begin{array}{l}108 \text { samples } \\
73.0 \text { percent of samples }\end{array}$ \\
\hline \multicolumn{1}{c}{ Variable } & Median & Median & p-value \\
\hline 1990 population density, people per square kilometer & 9.72 & 16.22 & 0.0908 (NS) \\
Urban land use, percent & 0.11 & 2.10 & $\mathbf{0 . 0 2 2 4}$ \\
Dissolved oxygen, mg/L & 0.10 & 0.33 & $\mathbf{0 . 0 0 0 1}$ \\
Dissolved organic carbon, $\mathrm{mg} / \mathrm{L}$ & 1.05 & & \\
\hline
\end{tabular}


the unconfined area in southwestern Georgia, about 69 percent of samples contained pesticide detections, compared to less than 20 percent of samples in the other four sampling networks (fig. 25).

The most frequently detected pesticides were the herbicides atrazine, detected in about 10 percent of samples, deethylatrazine (a degradate of atrazine) detected in about 9 percent of samples, metolachlor detected in 7 percent of samples, and alachlor detected in about 5 percent of samples (fig. 26). A degradate is a compound formed by the trans-formation of a pesticide by chemical, photochemical, or biological reactions. Simazine was detected in about 4 percent of samples and tebuthiuron was detected in about 3 percent

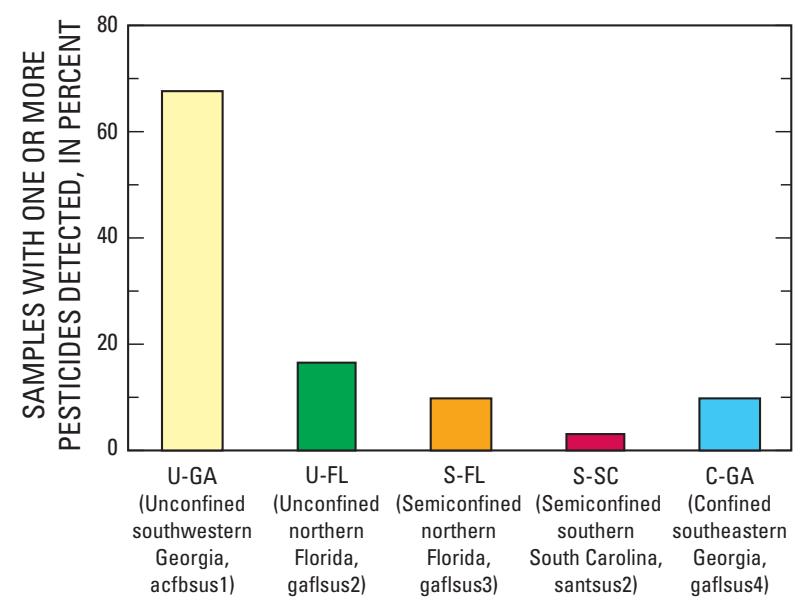

Figure 25. Detection frequencies for samples with pesticide detections in each sampling network.

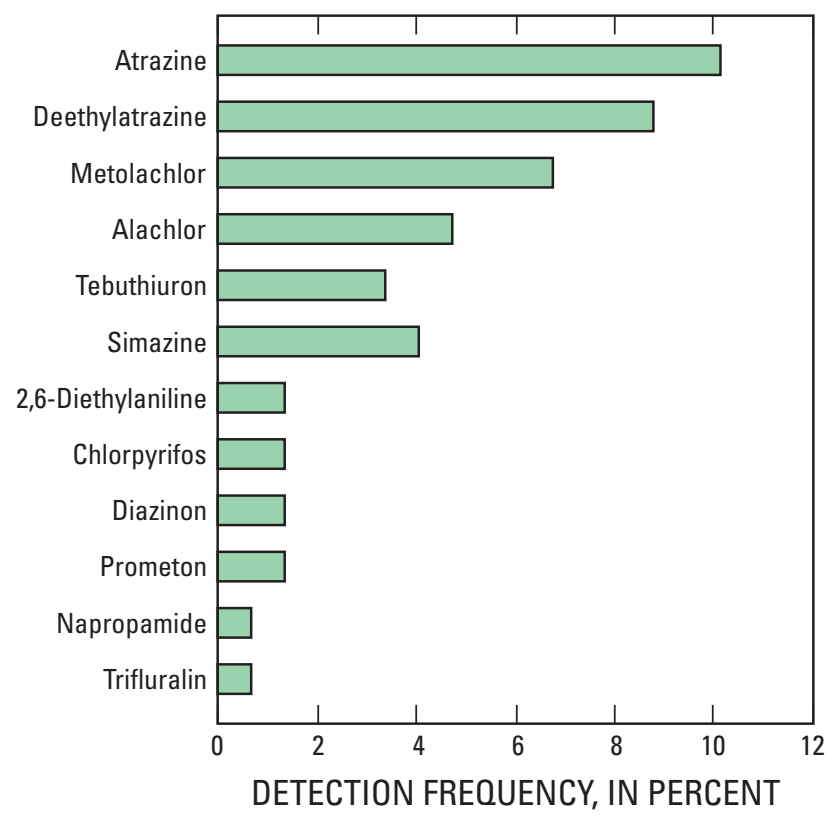

Figure 26. Detection frequencies for pesticides detected in 1 percent or more of samples. of samples. The remaining pesticides were detected in 1 percent or less of the samples. Atrazine, deethylatrazine, and metolachlor were also the pesticides most frequently detected in groundwater from NAWQA studies across the Nation, and their frequency of occurrence is attributed to their high application rates and their mobility and persistence in the hydrologic system (Gilliom and others, 2006).

\section{Comparison to Water-Quality Benchmarks for Human Health}

Concentrations of pesticides typically were low with nearly 99 percent of the detections at concentrations less than $0.6 \mu \mathrm{g} / \mathrm{L}$. Maximum concentrations for the most frequently detected pesticides (all herbicides) were $0.02 \mu \mathrm{g} / \mathrm{L}$ for atrazine, $0.03 \mu \mathrm{g} / \mathrm{L}$ for deethylatrazine, $0.03 \mu \mathrm{g} / \mathrm{L}$ for metolachlor, and $0.52 \mu \mathrm{g} / \mathrm{L}$ for alachlor (fig. 22). The maximum concentration of any pesticide was $2.09 \mu \mathrm{g} / \mathrm{L}$ for tebuthiuron, in a sample from the unconfined area in southwestern Georgia (fig. 22). This concentration is several orders of magnitude lower than the HBSL of 1,000 $\mu \mathrm{g} / \mathrm{L}$ (Toccalino and others, 2007). Comparison of pesticide concentrations to human-health benchmarks (MCLs and HBSLs) showed that no pesticides were detected at concentrations greater than the MCL or HBSL although one pesticide, alachlor, had a benchmark quotient value greater than 0.1 (within 10 percent of the benchmark) in a sample from the unconfined area in southwestern Georgia.

\section{Factors Affecting Pesticide Detections}

The herbicides atrazine, deethylatrazine, metolachlor, and alachlor were most frequently detected in samples from the unconfined category and the agriculture land-use category (fig. 27A-B). These herbicides were detected in about 12 to 25 percent of samples from the unconfined category, compared to less than 5 percent in the semiconfined and confined categories. Because many of the sites in unconfined areas are also designated in the agriculture category, detection rates for these herbicides were also greatest in the agriculture category. Detection rates for atrazine, deethylatrazine, metolachlor, and alachlor ranged from about 10 to 21 percent for agriculture category (fig. 27B). In the urban category, detection rates for atrazine and deethylatrazine were about 7 percent, reflecting the use of atrazine for weed control in residential and urban settings. In the undeveloped land-use category, atrazine was detected in 8 percent of samples and deethylatrazine and metolachlor were detected in 5 percent of samples.

Statistical comparisons were made to assess the effect of selected factors on the occurrence of atrazine in the Upper Floridan aquifer. The Wilcoxon rank-sum test was used to compare the medians for selected chemical factors (dissolved oxygen, nitrate and dissolved organic carbon) and anthropogenic factors (land-use, nitrogen sources, and pesticide applications) between samples that contained detections of atrazine and samples without atrazine detections. 

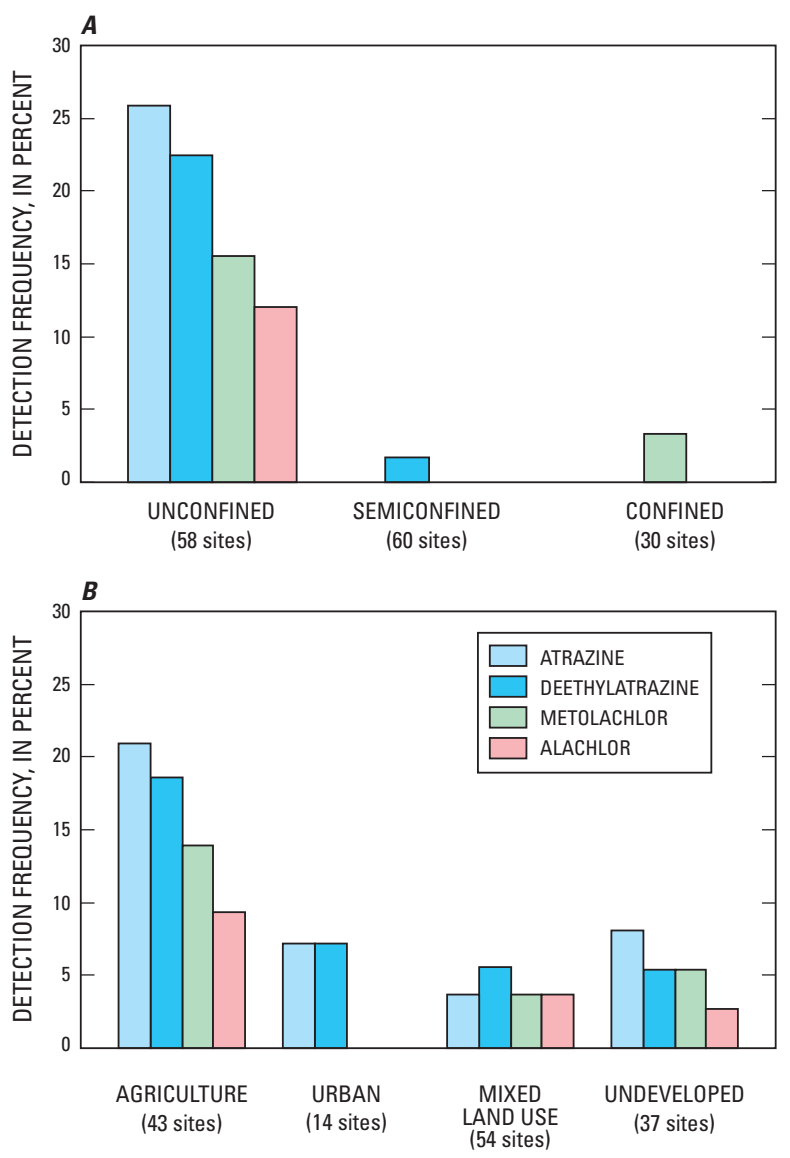

Figure 27. Detection frequencies for atrazine, deethylatrazine, metolachlor, and alachlor by $A$, confinement category and $B$, land-use category.
Because atrazine detections only occurred in the unconfined category (fig. 27A), comparisons were only made for samples from this category. About 87 percent of the 15 samples with atrazine detections also had deethylatrazine detections, and 40 percent had metolachlor detections (table 16). Statistical results indicated that samples with atrazine detections had significantly higher nitrate concentrations, dissolved oxygen concentrations, and nitrogen fertilizer loads and significantly lower dissolved organic carbon concentration than samples without atrazine detections. The samples with atrazine detected also had significantly higher amounts of atrazine application rates within the 500-m-radius area surrounding the well than samples without atrazine detections (table 16). For the 15 samples with atrazine detections, the median application rate of atrazine within the 500-m-radius area was $2.5 \mathrm{~kg} / \mathrm{yr}$ compared to atrazine application rates of about $0.6 \mathrm{~kg} / \mathrm{yr}$ for the samples without atrazine detections (table 16). The atrazine application rate is derived from the pesticide use per county and apportioned based on the percentage of land area in row crops, small-grain crops, and fallow lands (Nakagaki and Wolock, 2005). These results indicate that atrazine detections in the Upper Floridan aquifer are associated with high atrazine applications, shallow wells, and oxic groundwater (dissolved oxygen greater than $0.5 \mathrm{mg} / \mathrm{L}$ ), conditions that were observed in the unconfined area in southwestern Georgia.

Table 16. Results of the Wilcoxon rank-sum test comparing median values for selected chemical and anthropogenic factors between samples with atrazine detections and samples without atrazine detections.

$[\mathrm{mg} / \mathrm{L}$, milligrams per liter; $\mathrm{p}$-values less than the alpha value of 0.05 indicate significant difference and are shown in bold; NS, correlation not significant at an alpha value of 0.05 ]

\begin{tabular}{lccc}
\hline & $\begin{array}{c}\text { Atrazine detected } \\
\text { 15 samples }\end{array}$ & $\begin{array}{l}\text { Atrazine not detected } \\
\text { 43 samples }\end{array}$ \\
\hline Deethylatrazine detection rate, in percent & 86.7 & 0.0 & p-value \\
Metolachlor detection rate, in percent & 40.0 & 9.3 & $\mathbf{0 . 0 1 1 2}$ \\
\hline \multicolumn{1}{c}{ Variable } & Median & Median & $\mathbf{0 . 0 0 2 5}$ \\
\hline Atrazine, kilograms per year & 2.5 & 0.6 & 0.2867 (NS) \\
Nitrogen load from agriculture, & 2671 & 937 & $\mathbf{0 . 0 0 8 1}$ \\
$\quad$ & & 53 & $\mathbf{0 . 0 0 1 3}$ \\
Agricultural land, percent & 64 & 80.5 & $\mathbf{0 . 0 0 2 1}$ \\
Well depth, feet below land surface & 140.0 & 1.15 & $\mathbf{0 . 0 0 2 9}$ \\
Nitrate, mg/L & 2.46 & 2.80 & 0.33 \\
Dissolved oxygen, mg/L & 5.90 & 0.24 & \\
Dissolved organic carbon, mg/L & & & \\
\hline
\end{tabular}




\section{Summary}

Water-quality analyses of samples from 148 domestic wells completed in the Upper Floridan aquifer indicated that the water in this aquifer is of good quality. Maximum contaminant levels (MCLs) for drinking water were only exceeded for fluoride, where 2 samples (about 1 percent of samples) had concentrations greater than the MCL of $4 \mathrm{mg} / \mathrm{L}$ (milligrams per liter). The Upper Floridan aquifer is used as drinking water for about 10 million people, mostly in Florida and Georgia. Results of the inorganic geochemistry analyses indicate that the dissolution of calcite and dolomite controls the major ion chemistry. Cation exchange of major ions in water with underlying sediments was evident in South Carolina. Effects of aquifer confinement on groundwater geochemistry are seen in the higher concentrations of dissolved oxygen in groundwater in unconfined areas compared to semiconfined or confined areas. Median concentrations of dissolved oxygen were highest in samples from unconfined areas in southwestern Georgia $(5.7 \mathrm{mg} / \mathrm{L})$ and northern Florida $(2.2 \mathrm{mg} / \mathrm{L})$. Median concentrations were less than $1 \mathrm{mg} / \mathrm{L}$ for samples from the three networks in semiconfined or confined areas.

Results of trace element analyses indicated that most concentrations are low or not detected at a reporting level of $1.0 \mu \mathrm{g} / \mathrm{L}$ (micrograms per liter), except for strontium and a few samples (13 and 3 percent) that had iron or manganese concentrations greater than the Secondary Maximum Contaminant Levels (SMCLs) of 300 and $50 \mu \mathrm{g} / \mathrm{L}$, respectively. Radon concentrations were variable and ranged from 10 to $6,000 \mathrm{pCi} / \mathrm{L}$ (picocuries per liter), and about 40 percent of samples had concentrations greater than the proposed MCL of $300 \mathrm{pCi} / \mathrm{L}$. The variable concentrations did not appear related to aquifer confinement and probably reflect spatial differences in lithology of the aquifer materials or overlying materials.

The effects of confinement and land use were evident in the occurrence and distribution of nitrate in the Upper Floridan aquifer. Overall, nitrate concentrations were low (median less than $0.06 \mathrm{mg} / \mathrm{L}$ ), but were significantly higher in one sampling network in the unconfined area in southwestern Georgia than in the other four sampling networks, including samples from a sampling network in an unconfined area in northern Florida. Although the percentage of agricultural land surrounding wells was similar in the two unconfined networks, the estimated amount of nitrogen applied as fertilizer was twice as high in the network in the unconfined area in southwestern Georgia than in the network in the unconfined area in northern Florida. This finding reflects the greater intensity of agricultural practices (related to crop types and their associated fertilizer requirements) in the unconfined area in southwestern Georgia relative to the unconfined area in northern Florida. Dissolved oxygen concentrations were mostly greater than $0.5 \mathrm{mg} / \mathrm{L}$ in these unconfined areas and were not correlated with nitrate concentrations; specifically, higher dissolved oxygen concentrations were not associated with higher nitrate concentrations.

The occurrence and distribution of volatile organic compounds (VOCs) and pesticides also were related to the effects of confinement and land use. Overall, most concentrations of both groups of compounds were low (less than $1 \mu \mathrm{g} / \mathrm{L}$ ) and no drinking-water standards were exceeded. More VOCs were detected (24 compounds) than pesticides (12 compounds); VOCs were detected in more samples (55 percent) than pesticides (21 percent); and concentrations of most VOCs were about an order of magnitude higher than most pesticide concentrations. Concentrations of the three most frequently detected VOCs - chloroform, carbon disulfide and 1,2-dichloropropane - ranged from 0.01 to $1.14 \mu \mathrm{g} / \mathrm{L}$. Chloroform, a byproduct of chlorination, was detected in 29 percent of samples and was most frequently detected in unconfined areas and in urban areas, which is similar to nationwide NAWQA results. In contrast, carbon disulfide, a solvent that also has natural sources, was detected in 27 percent of samples and was most frequently detected in confined areas.

The most frequently detected pesticides were the herbicides atrazine, detected in about 10 percent of samples, deethylatrazine (a degradate of atrazine) detected in about 9 percent of samples, metolachlor detected in 7 percent of samples, and alachlor detected in about 5 percent of samples. Maximum pesticide concentrations for the most frequently detected pesticides (all herbicides) were $0.02 \mu \mathrm{g} / \mathrm{L}$ for atrazine, $0.03 \mu \mathrm{g} / \mathrm{L}$ for deethylatrazine, $0.03 \mu \mathrm{g} / \mathrm{L}$ for metolachlor, and $0.52 \mu \mathrm{g} / \mathrm{L}$ for alachlor. Atrazine and alachlor were only detected in unconfined areas and atrazine, deethylatrazine, metolachlor, and alachlor were most frequently detected in agricultural settings where the estimated atrazine application rate near well sites was greatest. Results of nonparametric statistics showed that, among samples from unconfined areas, samples with atrazine detections had significantly higher nitrate, dissolved oxygen, and applications of nitrogen fertilizer and atrazine than those without detections. 


\section{References Cited}

Berndt, M.P., 1996, Ground-water quality assessment of the Georgia-Florida Coastal Plain study unit-Analysis of available information on nutrients, 1972-92: U.S. Geological Survey Water-Resources Investigations Report 95-4039, 39 p.

Brahana, J.V., Thrailkill, J., Freeman, T., and Ward, W.C., 1988, Carbonate rocks, in Back, W., Rosenshein, J.S., and Seaber, P.R., eds., The geology of North America, v. O-2, Hydrogeology: Boulder, Colorado, Geological Society of America, p. 333-352.

Bush, P.W., and Johnston, R.H., 1988, Ground-water hydraulics, regional flow, and ground-water development of the Floridan aquifer system in Florida and parts of Georgia, South Carolina, and Alabama: U.S. Geological Survey Professional Paper 1403-C, 80 p.

Cecil, L.D., and Green, J.R., 2000, Radon-222, in Cook, P., and Herczeg, A.L., eds., Environmental Tracers in Subsurface Hydrolog: Boston, Massachussetts, Kluwer Academic Publishers, chap. 6, p. 175-194.

Charlton, S.R., and Parkhurst, D.L., 2002, PHREEQCI-A graphical user interface to the geochemical model PHREEQC: U.S. Geological Survey Fact Sheet FS-031-02, 2 p.

Gilliom, R.J., Barbash, J.E., Crawford, C.G., Hamilton, P.A., Martin, J.D., Nakagaki, Naomi, Nowell, L.H., Scott, J.C., Stackelberg, P.E., Thelin, G.P., and Wolock, D.M., 2006, The quality of our Nation's waters-Pesticides in the Nation's streams and groundwater, 1992-2001: U.S. Geological Survey Circular 1291, 172 p., accessed December 18, 2007, at http://pubs.water.usgs.gov/ circ1291/

Helsel, D.R., 2005, Nondetects and data analysis: Hoboken, N.J., John Wiley and Sons, Inc., 250 p.

Helsel, D.R., and Hirsch, R.M., 1992, Statistical methods in water resources: New York, Elsevier, 522 p.

Katz, B.G., 1992, Hydrochemistry of the upper Floridan aquifer, Florida: U.S. Geological Survey WaterResources Investigations Report 91-4196, 37 p., 10 pls.

Katz, B.G., Crandall, C.A., Metz, P.A., McBride, W.S., and Berndt, M.P., 2008, Chemical characteristics, water sources and pathways, and age distribution of groundwater in the contributing recharge area of a public-supply well near Tampa, Florida: 2002-05: U.S. Geological Survey Scientific Investigations Report 2007-5139, 83 p.

Koterba, M.T., Wilde, F.D., and Lapham, W.W., 1995, Ground-water data-collection protocols and procedures for the National Water-Quality Assessment Program: Collection and documentation of water-quality samples and related data: U.S. Geological Survey Open-File Report 95-399, 113 p.
Lapham, W.W., Hamilton, P.A., and Myers, D.N., 2005, National Water-Quality Assessment Program - Cycle II Regional assessments of aquifers: U.S. Geological Survey Fact Sheet 2005-3013, 4 p.

Lindsey, B.D., Berndt, M.P., Katz, B.G., Ardis, A.F., and Skach, K.A., 2009, Factors affecting water quality in selected carbonate aquifers in the United States, 19932005: U.S. Geological Survey Scientific Investigations Report 2008-5240, 117 p.

Marella, R.L., 2004, Water withdrawals, use, discharge, and trends in Florida, 2000: U.S. Geological Survey Scientific Investigations Report 2004-5151, 138 p.

Marella, R.L., and Berndt, M.P., 2005, Water withdrawals and trends from the Floridan aquifer system in the southeastern United States, 1950-2000: U.S. Geological Survey Circular 1278, 20 p.

McMahon, P.B., and Chapelle, F.H., 2008, Redox processes and water quality of selected principal aquifer systems: Groundwater, vol. 46, n. 2, p 259-271.

Metz, P.A., Delzer, G.C., Berndt, M.P., Crandall, C.A., and Toccalino, P.L., 2006, Anthropogenic organic compounds in groundwater and finished water of community water systems in the northern Tampa Bay area, Florida, 2002 04: U.S. Geological Survey Scientific Investigations Report 2006-5267, 48 p.

Miller, J.A., 1986, Hydrogeologic framework of the Floridan aquifer system in Florida and in parts of Georgia, South Carolina, and Alabama: U.S. Geological Survey Professional Paper 1403-B, 91 p., 33 pls.

Miller, J.A., 1990, Groundwater Atlas of the United States, Segment 6, Alabama, Florida, Georgia, and South Carolina: U.S. Geological Survey Hydrologic Investigation Atlas 730-G, 28 p.

Nakagaki, Naomi, and Wolock, D.M., 2005, Estimation of agricultural pesticide use in drainage basins using land cover maps and county pesticide data: U.S. Geological Survey Open-File Report 2005-1188.

Nolan, B.T., and Hitt, K.J., 2003, Nutrients in shallow groundwaters beneath relatively undeveloped areas in the conterminous United States: U.S. Geological Survey Water-Resources Investigations Report 02-4289, 17 p.

Parkhurst, D.L., and Appelo, C.A.J., 1999, User's guide to PHREEQC (Version 2)-A computer program for speciation, batch reaction, one-dimensional transport, and inverse geochemical calculations: U.S. Geological Survey Water-Resources Investigations Report 99-4259, $310 \mathrm{p}$.

Price, C.V., Nakagaki, Naomi , Hitt, K.J., and Clawges, R.M., 2007, Enhanced historical land-use and landcover data sets of the U.S. Geological Survey: U.S. Geological Survey Data Series 240 [digital data], at http://pubs.usgs. gov/ds/2006/240 
Ruddy, B.C., Lorenz, D.L., and Mueller, D.K., 2006, Countylevel estimates of nutrient inputs to the land surface of the conterminous United States, 1982-2001: U.S. Geological Survey Scientific Investigations Report 2006-5012, $17 \mathrm{p}$.

SAS Institute. Inc., 1989a, SAS/STAT user's guide, volume 1 (4th ed.): Cary, North Carolina, SAS Institute, Inc., $943 \mathrm{p}$.

SAS Institute, Inc., 1989b, SAS/STAT user's guide, volume 2 (4th ed.): Cary, North Carolina, SAS Institute, Inc., $846 \mathrm{p}$.

Sprinkle, C.L., 1989, Geochemistry of the Floridan aquifer system in Florida and parts of Georgia, South Carolina, and Alabama: U.S. Geological Survey Professional Paper 1403-I, 105 p., 9 pls.

Stumm, Werner, and Morgan, J.J., 1981, Aquatic chemistry: New York, John Wiley and Sons, 780 p.

Taglioli, B.L., Delzer, G.C., and Zogorski, J.S., 2001, Study design and analytical results used to evaluate carry-over contamination by volatile organic compounds in surfaceand ground-water sampling procedures: U.S. Geological Survey Open-File Report 2000-384, 36 p.

Tesoriero, A.J., Loffler, R.E., and Liebsher, H., 2001, Fate and origin of 1,2-dichloropropane in an unconfined shallow aquifer: Environmental Science and Technology, v. 35, p. $455-461$.

Toccalino, P.L., and Norman, J.E., 2006, Health-based screening levels to evaluate U.S. Geological Survey groundwater quality data: Risk Analysis, v. 26, no. 5, p. 1339-1348.

Toccalino, P.L., Norman, J.E., Booth, N.L., and Zogorski, J.S., 2007, Health-based screening levels-A tool for evaluating what water-quality data may mean to human health: U.S. Geological Survey, National Water-Quality Assessment Program, accessed on June 5, 2007, at http://water.usgs.gov/nawqa/HBSL/

Toccalino, P.L., Norman, J.E., Phillips, R.H., Kauffman, L.J., Stackelberg, P.E., Nowell, L.H., Krietzman, S.J., and Post, G.B., 2004, Application of health-based screening levels to ground-water quality data in a state-scale pilot effort: U.S. Geological Survey Scientific Investigations Report 2004-5174, 64 p.

Toccalino, P.L., Nowell, L.H., Wilber, W.G., Zogorski, J.S., Donohue, J.M., Eiden, C.A., Krietzman, S.J., and Post, G.B., 2003, Development of health-based screening levels for use in state- or local-scale water-quality assessments: U.S. Geological Survey Water-Resources Investigations Report 03-4054, 22 p.

Toccalino, P.T., Zogorski, J.S., and Norman, J.E., 2005, Health-based screening levels and their application to water-quality data: U.S. Geological Survey Fact Sheet 2005-3059, 2 p.

U.S. Bureau of the Census, 1990, Cartographic boundary files - 1990 Census block group [digital data]: accessed February 14, 2003, at http://www.census.gov/geo/www/ cob/bg1990.html
U.S. Bureau of the Census, 1991, Census of population and housing, 1990-Public Law (P.L.) 94-171: Washington, D.C. [digital data on CDROM].

U.S. Bureau of the Census, 1992, Census of population and housing-Summary tape file 3A: Washington, D.C. [digital data on CDROM].

U.S. Department of Agriculture, 1994, State soil geographic (STATSGO) data base for the United States and Puerto Rico: U.S. Department of Agriculture, Natural Resources Conservation Service [digital data on CDROM].

U.S. Department of Agriculture, 2007, Hydrologic soil groups, in National Engineering Handbook, Part 630 - Hydrology: U.S. Department of Agriculture, Natural Resources Conservation Service, Handbook 210-VINEH 630.07, chap. 7, 14 p.

U.S. Department of Labor, 2008, Occupational safety and health guideline for tetrahydrofuran: U.S. Department of Labor, Occupational Safety and Health Administration: Accessed on July 24, 2008 at http://www.osha.gov/SLTC/ healthguidelines/tetrahydrofuran/recognition.html

U.S. Environmental Protection Agency, 1994a, Chemical summary for carbon disulfide: Accessed August 16, 2007 at $h t t p: / / w w w . e p a . g o v / c h e m f a c t / s \_c a r b d s . t x t, 14 \mathrm{p}$.

U.S. Environmental Protection Agency, 1994b, Chemicals in the environment: carbon disulfide: Office of Pollution Prevention and Toxics, 3 p., accessed on August 16, 2007 at $h t t p: / / w w w . e p a . g o v / o p p t i n t r / c h e m f a c t / f$ carbds.txt

U.S. Environmental Protection Agency, 1999, Proposed radon in drinking water rule: U.S. Environmental Protection Agency Publication 815-F-99-006, 6 p.

U.S. Environmental Protection Agency, 2002, Onsite Wastewater Treatment Systems Manual, Office of Water, Office of Research and Development Report EPA/625/R-00/008, 175 p.

U.S. Environmental Protection Agency, 2006, 2006 Edition of the drinking water standards and health advisories: Office of Water, EPA 822-R-06-013, 18 p.

Vogelmann, J.E., Howard, S.M., Yang, Limin, Larson, C.R., Wylie, B.K., and Van Driel, Nick, 2001, Completion of the 1990's national land cover dataset for the conterminous United States from Landsat thematic mapper data and ancillary data sources: Photogrammetric Engineering and Remote Sensing, v. 67, p. 650-662.

Waterloo Hydrogeologic, Inc., 2005, Aquachem Version 5.0 User's Manual: Waterloo, Ontario Canada, 328 p.

Wolock, D.M., 1997, STATSGO soil characteristics for the conterminous United States: U.S. Geological Survey Open-File Report 97-656 [digital data]. Accessed February 17, 2004, at http://water.usgs.gov/lookup/ getspatial?muid

Zogorski, J.S., Carter, J.M., Ivahnenko, Tamara, Lapham, W.W., Moran, M.J., Rowe, B.J., Squillace, P.J., and Toccalino, P.L., 2006, The quality of our Nation's waters-Volatile organic compounds in the Nation's groundwater and drinking-water supply wells: U.S. Geological Survey Circular 1292, 101 p. 


\section{Appendixes}



Appendix 1. Volatile organic compounds analyzed in water samples.

[Compounds in bold were detected in this study; $\mu \mathrm{g} / \mathrm{L}$, micrograms per liter]

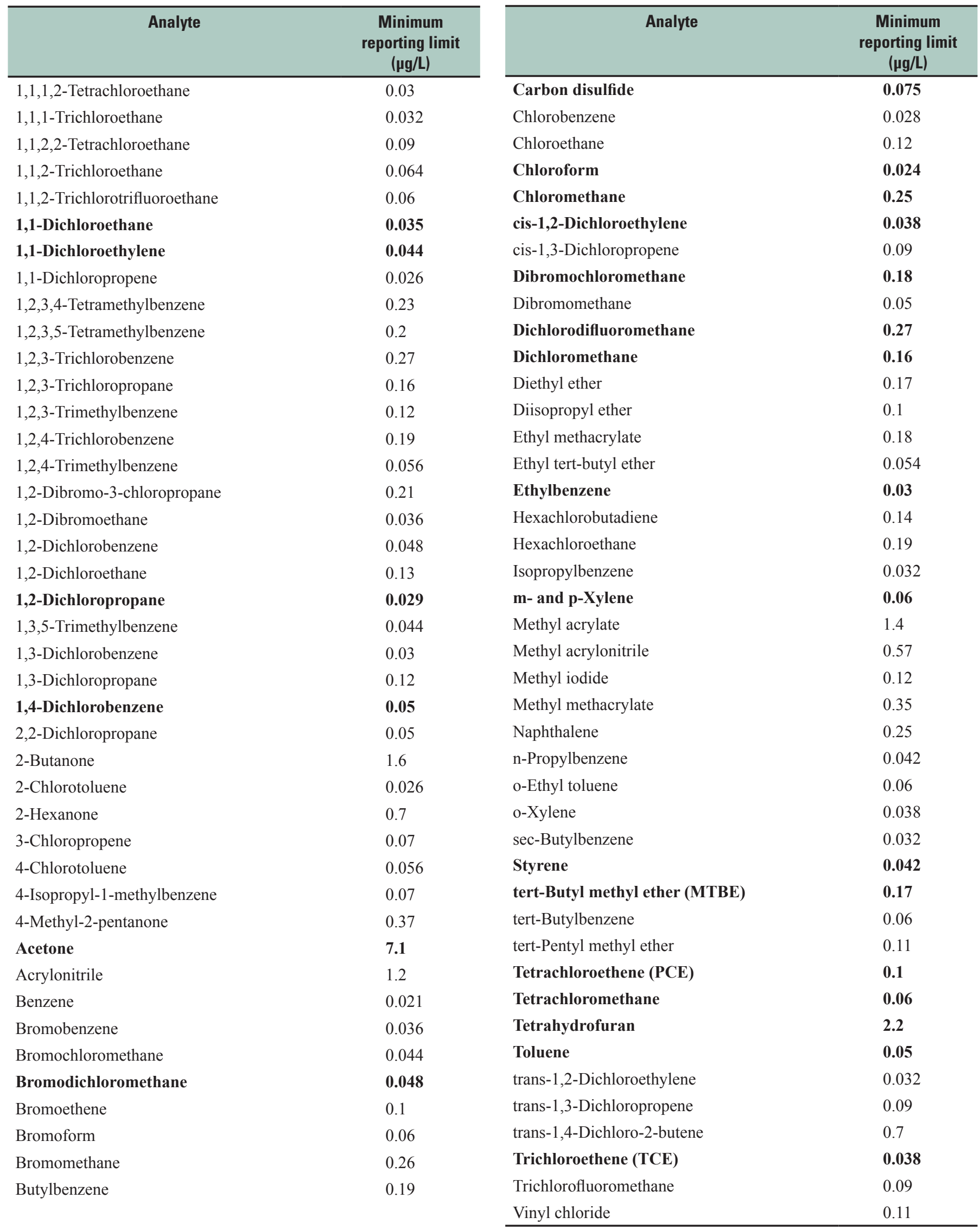


Appendix 2. Pesticides analyzed in water samples.

[Compounds in bold were detected in this study; $\mu \mathrm{g} / \mathrm{L}$, micrograms per liter]

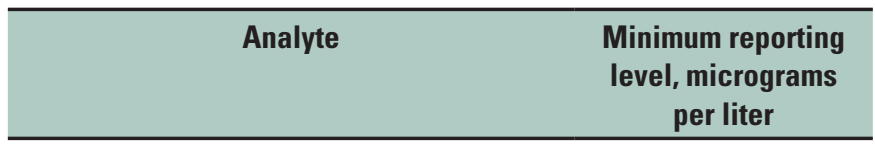

Pesticides analyzed in all 148 samples, 1998-2005

\section{2,6-Diethylaniline}

Acetochlor

Alachlor

Atrazine

Azinphos-methyl

Benfluralin

Carbaryl

Carbofuran

\section{Chlorpyrifos}

cis-Permethrin

Cyanazine

Dacthal

\section{Deethylatrazine}

Desulfinylfipronil

Desulfinylfipronil amide

\section{Diazinon}

0.006

Dieldrin

Disulfoton

EPTC (S-Ethyl dipropylthiocarbamate)

Ethoprophos

Fipronil

Fipronil sulfide

Fipronil sulfone

Fonofos

Malathion

\section{Metolachlor}

Metribuzin

Molinate

Parathion-methyl

Pendimethalin

Phorate

\section{Prometon}

Propanil

Propargite

Propyzamide

Simazine

Tebuthiuron

Terbufos

Thiobencarb

Trifluralin
0.006

0.005

0.007

0.05

0.01

0.041

0.02

0.005

0.006

0.018

0.003

0.014

0.012

0.029

0.005

0.009

0.021

0.004

0.012

0.016

0.013

0.024

0.0053

0.027

0.006

0.028

0.003

0.015

0.022

0.055

0.01

0.011

0.023

0.004

0.005

0.016

0.017

0.01

0.009

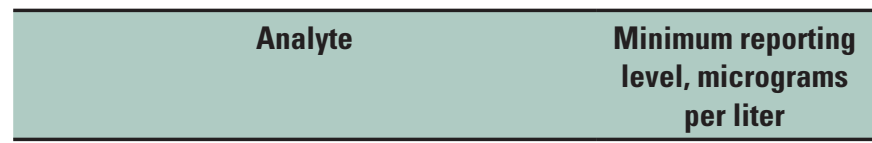

Pesticides analyzed in 118 samples from unconfined and semiconfined areas, 1998-2002

$\begin{array}{ll}\text { alpha-HCH } & 0.005 \\ \text { Butylate } & 0.004 \\ \text { Ethalfluralin } & 0.009 \\ \text { Lindane } & 0.004 \\ \text { Linuron } & 0.035 \\ \text { Napropamide } & \mathbf{0 . 0 0 7} \\ \text { p,p'-DDE } & 0.003 \\ \text { Parathion } & 0.01 \\ \text { Pebulate } & 0.004 \\ \text { Propachlor } & 0.01 \\ \text { Terbacil } & 0.034 \\ \text { Tri-allate } & 0.006\end{array}$

Pesticides analyzed in 30 samples from confined areas, 2005

1-Naphthol

0.0882

2-Chloro-2,6-diethylacetanilide

0.0065

2-Ethyl-6-methylaniline

0.01

3,4-Dichloroaniline

0.0045

3,5-Dichloroaniline

0.012

4-Chloro-2-methylphenol

0.005

alpha-Endosulfan

0.011

Azinphos-methyl-oxon

0.042

Chlorpyrofos, oxygen analog

0.0562

cis-Propiconazole

0.013

Cyfluthrin

0.053

Cypermethrin

0.046

Diazinon, oxygen analog

0.006

Dichlorvos

0.013

Dicrotophos

0.0843

Dimethoate

0.0061

Disulfoton sulfone

0.014

Endosulfan sulfate

0.022

Ethion

0.016

Ethion monoxon

0.021

Fenamiphos

0.029

Fenamiphos sulfone

0.053

Fenamiphos sulfoxide

0.04

Hexazinone

0.026

Iprodione

0.026 
Appendix 2. Pesticides analyzed in water samples.-Continued

[Compounds in bold were detected in this study; $\mu \mathrm{g} / \mathrm{L}$, micrograms per liter]

\begin{tabular}{ll}
\hline \multicolumn{1}{c}{ Analyte } & $\begin{array}{c}\text { Minimum reporting } \\
\text { level, micrograms } \\
\text { per liter }\end{array}$ \\
\hline Isofenphos & 0.011 \\
lambda-Cyhalothrin & 0.014 \\
Malaoxon & 0.039 \\
Metalaxyl & 0.0069 \\
Methidathion & 0.0087 \\
Myclobutanil & 0.033 \\
Oxyfluorfen & 0.017 \\
Paraoxon-methyl & 0.019 \\
Phorate oxygen analog & 0.027 \\
Phosmet & 0.0079 \\
Phosmet oxon & 0.0511 \\
Prometryn & 0.0059 \\
Tebuconazole & 0.0136 \\
Tefluthrin & 0.0033 \\
Terbufos oxygen analog sulfone & 0.045 \\
Terbuthylazine & 0.0083 \\
trans-Propiconazole & 0.034 \\
Tribufos & 0.035 \\
\hline
\end{tabular}

